\title{
Index for Volume 103
}

AUTHOR AND SUBJECT INDEX. Page numbers of errata are in italic.

Aadum, B. B., S2.124

AAL-toxin, 733

Abad, G., 1204

Abad, J., S2.76

Abad, J. A., S2.1, S2.5

Abad, Z. G., S2.179

Abatzoglou, J., 1130

Abawi, G. S., S2.1

Abbas, H., S2.158

Abbas, H. K., S2.68, S2.176

$\mathrm{ABC}$ genes, $\mathrm{S} 2.78$

Abdalla, O., S2.1, S2.5

Abdelsamad, N., S2.2

Abdullah, S., S2.4, S3.1

Abeysekara, N. S., S3.1

Abildgaard, M., S3.12

Abou Ghanem-Sabanadzovic, N. J., S1.5, S2.2, S2.59, S2.87, S2.125

Abraham-Juarez, M. D., S2.41

Abreu, L. M., S2.113, S2.122

Abro, M. A., 261

ACC oxidase, $\mathrm{S} 4.2$

Acetosyringone, 888

Acevedo, M., S2.37, S3.2, S3.3, S3.5, S3.9

Achata Bottger, J., S2.2

Achor, D. S., 488, 545, S2.124

Acibenzolar-S-methyl (ASM)

control of bacterial diseases and PR-gene induction, S2.79

control of citrus canker, S2.52

control of downy mildew of basil, S2.95

induction of antiviral responses against Cucurbit chlorotic yellow virus in melon, 960

Acidovorax citrulli, S2.37

Acid protease, production by fungal root endophytes, S2.92

Aćimović, S. G., S2.2

Acosta-Leal, R., S3.1

acr genes, S2.164

Actin

imaging the actin cytoskeleton in Aspergillus nidulans, S2.186

localization and dynamics in Aspergillus nidulans, S2.60

Actin contractile ring, $\mathrm{S} 2.187$

Actinidia deliciosa. See Kiwi

Actinomycetes, characterization of plant growthpromoting and disease suppressing abilities in isolates from groundnut rhizosphere, S2.66

Adachi, N., S2.174

Adams, G., S2.2

Adams, G. C., 190

Adams, M. J., 949

Adaskaveg, J., S2.3, S2.138

Ader, D., S2.140

ADiv project, S2.142

Adkins, S., 1243, S2.137, S2.158, S3.13

Adult-plant resistance, to virulence of Puccinia

striiformis f. sp. tritici in wheat, S2.97

Aerial blight, S2.42

Aerosols, analysis for microorganisms, S1.2

Afkhami, M. E., S2.55, S2.165

Afla-Guard, S2.158

Aflatoxin

effect of sexual recombination on population diversity in aflatoxin production by Aspergillus flavus, S1.8

human exposure to in mesquite pod flour products, S2.47

influences of weather on concentrations in crops, S2.175

in maize accumulation in IITA-ARS lines, S1.2 corn smut galls, S2.176

etiology of contamination in Zambia, S2.70

impact of the Midwest 2012 drought on, S2.175

management with Afla-Guard, S2.158

transgenic approaches to control, S2.127

reduction in pistachio orchards with

biopesticide AF36, S2.175

Aflatoxin $\mathrm{B}_{1}$, contamination of groundnut, S2.104

Aflatoxin-producing fungi, effect of weather on,

S2.175

African horned cucumber (Cucumis metulifer),

S2.144

Agaricales, S2.142

Agaric fungi, evolutionary consequences of intra-

and interspecific hybridization in, S2.63

Agaricomycotina, S2.181

Agaricus bisporus, S2.158

Agindotan, B. O., S2.3

Agra, L. A. N., S2.3

Agricultural biosecurity

masters-level education, S2.189

next generation sequencing and, S2.33

recent innovations, $\mathrm{S} 2.176$

Agrobacterium tumefaciens

effects of Tzs protein and exogenous

cytokinin on virulence gene expression and growth, 888

impact of biological amendments on survival in soil, S2.140

Agrobacterium tumefaciens-mediated

transformation, using to create gene knockouts

in Setosphaeria turcica, 641

Agrobacterium vitis

distribution and detection in vines, S2.69

magnetic capture hybridization real-time PCR assays, 633

strain ARK-1, biological control of grape crown gall, S2.71

strain F2/5, host-specific biological control of grape crown gall, 427

Aguayo, J., 190

Agudelo, P., S2.131

Aguilar Moreno, G. S., S2.9

Aguirre-Rayo, J. M., S2.134

Ahern, S. J., S2.34

Ahmed, A., S2.24

Ahmed, T., S3.8

Ailloud, F., S2.3, S2.66

Aime, M. C., S2.4, S2.35, S2.58, S2.74, S2.85,

S2.94, S2.102, S2.135, S2.146, S2.150

AI-2 signaling, 352

Ajayi, O. O., S2.3

Akutsu, K., 513

Alabi, O., S2.20, S2.114

Alaraby, W., S2.4

Albers, C. R., S1.1, S2.161

Albu, S., S2.4, S2.158

Alder, building an index of pathogens, S2.2

Alder decline, 190

Alderman, S. C., S2.37

Aldrich-Wolfe, L., S2.27

Aldwinckle, H. S., S2.31

Alfaro, A. P., S2.60

Alfenas, A. C., S2.43, S2.107, S2.123

Al-Haddad, J., S2.117

Alhudaib, K., S2.4

Ali, A., S2.1, S2.4

Ali, G. S., S2.4, S2.73

Ali, N., S3.11

Ali, S., S2.4, S2.48, S2.78, S3.1

Ali, S. A., S2.38

Ali, S. S., 1260
Alkaloids, evolution, S2.109

Alkharouf, N., S2.98

Allan, E., S2.5

Allan, J., S3.12

Allele mining, functional analysis of the

resistance gene Pid3-A4 in wild rice, 594

Alleman, M., S1.2

Allen, C., S2.3, S2.32, S2.66, S2.86, S2.147

Allende-Molar, R., S3.11, S3.14

Allen, J., S2.47

Allen, T., S2.153, S2.158

Allen, T. W., S1.1, S1.4, S1.10, S2.49, S2.146, S2.168

Allium white rot, integrated control, S2.173

Almader, A., S2.5

Almeida, C. H. L. N., S2.67

Almeyda, C. V., S2.5

Almond trunk cankers, S3.12

Alnus, ectomycorrhizal fungi, S2.124, S2.182

Alnus acuminata, S2.122

Alphaflexiviridae, S2.188

Alpuche-Gonzalez, C., S2.5

Al Rwahnih, M., 1069, S2.3, S2.4

Al-Saleh, M., S2.5, S3.13

Alsanius, B. W., 1001

Al-Shahwan, I., S2.5

Alternanthera mosaic virus (AltMV), S2.188

Alternaria alternata

competitiveness of field QoI-resistant isolates, S2.152

nonhost resistance of Arabidopsis thaliana, 733

pathogenicity and aggressiveness on potato, S2.149

signatures of recombination in clonal lineages, 74

Alternaria brassicicola, 841

Alternaria brown spot of tangerine,

competitiveness of field QoI-resistant isolates,

S2.152

Alternaria cucumerina resistance, mapping in

Cucumis melo, $\mathrm{S} 2.32$

Alternaria late blight of pistachio, reducing

fungicide applications to control, S3.15

Alternaria solani, pathogenicity and

aggressiveness on potato, S2.149

Alternaria spp.

in the Bogotá plateau, S2.151

fungicide resistance in populations from

California pistachio orchards, S3.11

new species from Korea, S2.165

phylogenetic lineages within, S2.162 resistance to azoxystrobin and bosacilid in the Columbia Basin, S3.17

Alternaria stem canker on tomato, 733

Alternaria triticina, pathogenicity and aggressiveness on potato, S2.149

Altier, C., S2.95

Alvarado-Rosales, D., S2.39

Alvarado, V. Y., S2.105

Alvarez, A. M., 1220, S2.6, S2.10, S2.128

Alvarez-Garcia, A., S2.57

Alvarez, R. A., S2.117

Alves, E., S2.6, S2.143, S4.3

Alves, M. C., S2.151

Amaradasa, B., S2.76, S3.1

Ambrosia beetles

fungi isolated from stressed black walnut, S 2.120

Fusarium symbionts are pathogens of avocado, S2.114

lateral transfer of a phytopathogenic symbiont, S2.114

phylogenetic diversity of Fusarium fusaria cultivated by, S2.71 
Ambrosia Fusarium Clade (AFC), S2.71

Amenity trees, bacterial leaf scorch in

Washington D. C., S4.2

Amer, M., S2.5

Ames, K. A., S2.94, S3.6

Amiri, A., S2.51, S2.107, S2.112

Ammar, E. D., S2.171

Ammophila arenaria, S2.69

Ammophila breviligulata, S2.183

Amore, T. D., S2.6

Amorim, L., S2.104

Amplex Red probe, $\mathrm{S} 2.24$

Amsden, B., S2.6

Amundsen, K., S3.1

Anadenobolus monilicornis, S2.29

Anaerobic soil disinfestation (ASD)

bacterial population changes in fields treated with, S2.61

in suppression of Rhizoctonia root rot of apple, S2.60

Analytical and theoretical plant pathology calculating fungicide dose decisions, 666 disease risk curves, 1108

fungicide application timings for disease control are an effective anti-resistance strategy, 1209

modeling study of biocontrol agents controlling foliar pathogens, 108

relating the progeny production curve to the speed of an epidemic, 204

roguing with replacement in perennial crops, 117

spatial frailty modeling in survival analysis of cucurbit downy mildew epidemics, 216

synergy from the combined use of two biocontrol agents, 768

Anchieta, A., 268

Anco, D., S2.6

Ancona, V., S2.6

Andersen, K. F., S2.7

Anders, M. M., S2.150, S2.168

Anderson, G., S3.2

Anderson, G. M., S3.5

Anderson, J. B., S2.7

Anderson, M. M., 1069, S2.4, S2.140

Anderson, N. A., S2.108

Anderson, S., S2.7

Andrade-Piedra, J., S2.145, S3.8

Andreason, S., S2.7

Angel, C., S2.7, S2.43, S2.122, S2.188

Anishchenko, I. M., S2.53

Anisogramma anomala, S2.100, S3.15

Annis, S., S2.7, S2.8

Annual bluegrass, assessment of anthracnose severity, S2.65

Annual vinca (Catharanthus roseus), S2.155

Anselm, R., S2.141

Anther smut disease, assessment of infection susceptibility in the Montiaceae, S2.58

Anthracnose

in annual bluegrass, assessment of, S2.65 in bean, transmissibility by seed, S2.133 graminicolous anthracnose fungi, 575 in papaya fruits, caused by Colletotrichum spp., S3.11

in pecan, effects of fungicides on the latent stage of, S1.5

in soybean, real-time PCR detection and differentiation of Colletotrichum species causing, S2.164

in spinach, biology and management, S1.3 in strawberry

effect of inoculum concentration on

development of, S2.45

evaluation of fungicide applications, S2.112

unraveling anthracnose pathogens in legumes, S2.33
Anthracnose crown rot. See Colletotrichum gloeosporioides

Anthracnose resistance, screening strawberry germplasm for, S2.97

Anthurium

biological control of bacterial blight, S2.6 blight susceptibility index, S2.6

Antibiosis, in the suppression of clubroot on canola by Serenade, 245

Antilla, L., S3.13

Antonetti, J., S2.34

Antony, G., S2.88

Antrodia, S2.108

Aoki, T., 400, S2.71

Aoun, M., S3.2

Aphids

feeding behavior in somatic fusions and crosses of Solanum bublocastanum and $S$. tuberosum, S1.3

protein biomarkers linked to transmission competent and transmission refractive populations, S2.65

transformative technologies from knowledge of virus-aphid vector interactions, S3.2

transmission of Soybean mosaic virus, 941

Aphis glycines, 941

Apioplagiostoma populi, S2.108

Appel, D., S1.7

Apples (Malus $\times$ domestica)

anaerobic soil disinfestation in suppression of Rhizoctonia root rot, S2.60

changes in rhizosphere microbiome with

Brassicaceae seed meal amendment, S2.92

control of apple scab with foliar applications of phosphite fungicide, S2.39

diversity of sooty blotch and flyspeck fungi in Spain, S2.12

Erwinia amylovora presence in asymptomatic apple bud wood, S2.31

Phacidiopycnis washingtonensis infection, S2.133

phenology of infection by sooty blotch and flyspeck, S2.65

postharvest fruit rot caused by Lambertella sp., S2.160

pyrimethanil-resistance phenotypes of

Penicillium expansum from, S2.22

relationship of increased fungicide use to pesticide risk, S2.29

sources and availability of Sphaeropsis pyriputrescens inoculum, S2.163

trunk injection in control of apple scab, S2.2 trunk injection in control of fire blight, S2.2

Apple scab

control with foliar applications of phosphite fungicide, S2.39

control with trunk injections of biopesticides and fungicides, S2.2

leaf-shredding as a component of integrated management for, S2.154

molecular characterization, S2.75

See also Venturia inaequalis

AP-toxin, 135

Aquatic plants, fungal symbionts, S2.126

Aquino, O. M., 436

Arabidopsis

bacterial effector targeting of a non-canonical signaling pathway for suppressing defenses, S2.47

characterization of CRT1 in plant immunity and genome stability, S2.19

dimerization of CRT1, S2.70

nonhost resistance genes to defeat Asian soybean rust, $\mathrm{S} 2.77$

role of humidity and light in ArabidopsisPseudomonas interaction, S2.110

Arabidopsis thaliana

effect of Trichoderma volatile organic compounds on, S2.63 immunity induced by E. coli $\mathrm{O} 157: \mathrm{H} 7$ and Salmonella enterica Typhimurium SL1344, 326

nonhost resistance against Alternaria alternata, 733

pen mutants, 733

Arabis mosaic virus (ArMV), 1180

Arachis hypogaea. See Groundnut; Peanut

Ara, J., S2.18, S2.38

Arancibia, R. A., S1.10, S2.139

Aranda, M. A., 1188

Arano, E., S2.158

Arauz-Cavallini, F., S2.16

Arbuscular mycorrhizal fungi

an experimental test of the functioning of symbioses across scale, S2.181

effect of cover crops on colonization in watermelon roots, $\mathrm{S} 4.2$

factors affecting current distributions, S2.182 in marram grass, S2.69

molecular signaling in symbioses, $\mathrm{S} 2.187$

in Phoenix and the surrounding desert, S2.140

Arcibal, E., S2.8

Arcibal, S. S., S1.1

Arellano, C., 460

Arenas-Buitrago, Y., S3.17

Arendt, K., S2.8, S2.150, S2.161

ARGONAUTE proteins (AGOs), S2.105

Arguedas, M., S2.123

Arias De Ares, R. S., S1.9

Arias Rojas, N., S2.67

Arias, R. S., S2.115

Arias, S., S1.1

Arif, M., S2.7, S2.8, S2.9

Arismendi, N. L., S2.100

Arizona mesquite (Prosopis velutina), S2.47

Arlat, M., S2.170

Armaleo, D., S2.185

Armengol, J., 851

Armillaria

bioluminescence in, $\mathrm{S} 2.96$

genome-wide mutation dynamic, S2.7

Armillaria root disease, characterization in peach orchards in Mexico, S2.39

Arne, S., S2.9

Arnold, A. E., S2.8, S2.30, S2.48, S2.62, S2.126,

S2.130, S2.150, S2.161

Arnold, D. L., 1115

Arnold, E. A., S2.26

Arnold, K., S2.9

Arnthodi, A., S2.39

aroA gene, $\mathrm{S} 1.6$

aroB gene, $\mathrm{S} 1.6$

Arora, D., 1153

Arrebola, E., 1115

Arseneault, T., 995

Arthrinium phaeospermum, 135

Arthur, K. S., S2.174

Artificial microRNA-mediated resistance, 870

Aruppillai, S., S2.9

Arya, R., S2.9

Asalf, B., 717, S2.10, S2.14, S2.43

Asam, S., 1252

Ascomycetes

diversity and community structure of marine species from the Gulf of Mexico, S2.152

marine lignicolous ascomycetes from mangroves, S2.5

population genomics, S2.49

Ascophyllum extract, S3.11

Asellaria jatibonicua, S2.121

Ash, G. J., S2.10

Ashrafi, H. A., S2.101

Asian prunus viruses, S2.116

Asian soybean rust (ASR), S1.4, S2.77

Asiatic citrus bacterial canker. See Xanthomonas

citri subsp. citri

Asolkar, R. N., S2.146

Asparagus officinalis, S2.87 
Aspergillus ear rot, aflatoxin contamination in maize, S2.175

Aspergillus flavus

aflatoxin contamination in maize, S2.175

in corn ears in Indiana under the drought

conditions of 2012, S2.80

effect of sexual recombination on population diversity in aflatoxin production, $\mathrm{S} 1.8$

formulation development of nontoxigenic

biocontrol strain, S2.68

histology and transcriptional changes in corn seed infected by, $\mathrm{S} 2.133$

hybrids with A. minisclerotigenes, S2.32

maize lipoxygenase LOX2 regulates

pathogenicity of, S2.62

population structure before and after

biocontrol treatment, S2.106

potential roles of WRKY transcription factors

in corn defense against, S2.45

strain AF36

field performance as a biocontrol agent in cotton, S3.13

temporal dynamic of community structure in fields treated with, S2.66

using in pistachio orchards, S2.175

strain VCG YV36, variability in aflatoxin

biosynthesis gene cluster, $\mathrm{S} 2.108$

WRKY transcription factors and defense gene expression in corn, $\mathrm{S} 1.4$

See also Atoxigenic Aspergillus flavus

Aspergillus minisclerotigenes, S2.32

Aspergillus nidulans

early steps of the ergot alkaloid pathway, S4.3

imaging of the dynamic actin cytoskeleton,

S2.186

localization and dynamics of actin in, S2.60

Aspergillus niger, S2.175

Aspergillus niger-Y61, S2.116

Aspergillus section Flavi, genetic structure of soil

populations, S2.79

Aspergillus section Nigri, fumonisin production in maize, $\mathrm{S} 2.175$

Aspergillus spp.

effect of tassel fungicide applications on

harvested field corn, S1.1

multilocus database for identification, S2.113

oxidized lipids control disease development in maize, S2.19

Association mapping, 600

Astragalus pubentissimus, S2.12

Asymptomatic hosts, 538

AtBAG6, S2.79

Atkinson, George F., S2.60

Atkinson, S., S2.120

Atoxigenic Aspergillus flavus

evaluation of strains for aflatoxin control in corn, S2.65

genetic properties of isolates, $\mathrm{S} 2.5$

strain AF36

field performance as a biocontrol agent in cotton, S3.13

temporal dynamic of community structure in fields treated with, $\mathrm{S} 2.66$

using in pistachio orchards, S2.175

strain VCG YV36, variability in aflatoxin

biosynthesis gene cluster in, S2.108

vegetative compatibility group adapted to

maize production, $\mathrm{S} 2.105$

ATP-binding cassette (ABC) genes, S2.78

Attanayake, R. N., 750

Aureobasidium pullulans, S2.150

Austin, L., S2.74

Automated diagnostic primer design, S2.92

Autophagy, S2.79

Avellaneda, M. C., S2.10

Avenot, H. F., S3.11

Averett, D. R., 228

Avila-Adame, C., S2.10

Avila-Quezada, G. D., S3.12
aviR (quorum-sensing transcription factor), 427

Avirulence ( $A V R$ ) genes, in Magnaporthe oryzae,

S2.184

Avocado (Persea americana)

black spots caused by Neofusicoccum parvum in Mexico, S3.12

Fusarium symbionts of an ambrosia beetle are pathogens of, S2.114

laurel wilt, S2.114, S3.15

population genetic structure of Phytophthora cinnamomi, 91

AvrGf1, S2.168

AvrRxo1 virulence factor, S2.148

Awad, M. A., S2.39

Awokuse, T. O., S2.36

Ayin, C. M., S2.10

Azarmanesh, N., S2.101

Azegami, K., S2.174

Azoxystrobin

in combined use of PGPR strain MBI600 to control Rhizoctonia solani, S2.168

effect on conidial germination and mycelial growth in Didymella bryoniae, $\mathrm{S} 1.4$

Azoxystrobin resistance

in Alternaria spp. in the Colombia Basin, S3.17

monitoring in Rhizoctonia solani isolates

causing rice sheath blight, $\mathrm{S} 2.106$

stability in Didymella bryoniae, S2.43

Babadoost, M., S2.70, S2.119

Bacillus amyloliquefaciens, 146

Bacillus amyloliquefaciens FZB42, 1001

Bacillus mojavensis RRC101, S2.16

Bacillus spp.

black-pigmented strain with potential biocontrol capabilities, S2.74

efficacy as biocontrol agents for sheath blight and narrow brown leaf spot in organic rice, S2.168

plant growth promoting characteristics of species associated with Chenopodium quinoa, S2.144

sheath blight suppression by rice-associated strains, S1.9

strain F727, control of fungal plant pathogens, S2.146

Bacillus subtilis

common bean production under web blight and, S2.91

effect of non-Mexican strains on melon, S2.41

induced tolerance to damping-off in cotton, S2.94

strain IN937b, surfactin and biofilm production, S2.98

suppression of clubroot on canola, 245

Backman, P., S2.144, S2.191

Backus, E., S2.119

Bacon, C. W., 400, S2.11, S2.101

Bacterial apical necrosis of mango, 1115

Bacterial blight

of anthurium, S2.6

of common bean, multilocus sequence analysis, S2.106

of Pelargonium, S2.94

Bacterial canker of tomato. See Clavibacter

michiganensis subsp. michiganensis

Bacterial disease resistance, identifying novel

sources for rice, $\mathrm{S} 2.19$

Bacterial diseases control by phosphorous acid and acibenzolar$S$-methyl, S2.79

insect-transmitted, S2.171

rates of recombination and point mutation compared to bacterial vertebrate pathogens, $\mathrm{S} 2.23$

Bacterial endophytes, of switchgrass, S2.163

Bacterial fruit blotch of cucurbits, survival and seed transmission in citron melon, S2.37
Bacterial leaf scorch

of amenity trees in Washington D. C., S4.2

genetic characterization and radiation of,

S2.14

incidence and severity in a New Jersey urban

forest, $\mathrm{S} 2.51$

Bacterial leaf spot

of lettuce, S2.21

See also Xanthomonas perforans

Bacterial panicle blight of rice negative regulatory gene for toxoflavin production, S2.192

See also Burkholderia glumae

Bacterial pustule of soybean, S2.25

Bacterial rot of onions, S2.173

Bacterial spot

of pepper, molecular diagnosis, S2.74

of pumpkin

chemical and biocontrol agents for management, S2.144

detection in seed, S2.119

role of sRNAs in the virulence of

Xanthomonas campestris pv. vesicatoria,

S2 187

of stone fruit

leaf abscission and, S2.173

oxytetracycline resistance in, S2.11

of tomato

antibacterial activity of shiitake mycelial extracts, S2.105

development of biopesticide extractives

from switchgrass, S2.109

molecular diagnosis, S2.74

photocatalytic nanoscale formulations of titanium dioxide in control of, 228

ultrastructural action of essential oils of Xanthomonas vesicatoria, S2.6

Bacterial wilt

of common bean, attenuation by rhizobacteria,

S2.91

improved multiplex PCR and qPCR detection and identification, S2.140

See also Cucurbit bacterial wilt; Ralstonia solanacearum

Bacterial wilt resistance, evaluating tomato

rootstocks in North Carolina, S2.134

Bactericera cockerelli, 1235, S2.130

Bacteriology

acquisition of copper resistance genes in

citrus-associated Xanthomonas, 409

'Candidatus Liberibacter asiaticus'

heat treatment, 15

visualization of cells in citrus seed coat vascular bundles, 545

characterization of a Xanthomonas citri subsp. citri variant triggering a host-specific disease response, 555

effect of Zebra chip disease on tuber

physiology, 419

effects of Tzs protein and exogenous

cytokinin on virulence gene expression in

A. tumefaciens, 888

genetic analysis of Xanthomonas axonopodis pv. diffenbachiae, 237

genetic and virulence variability among

Erwinia tracheiphila strains, 900

genomic variability Spiroplasma kunkelii, 129

loop-mediated amplification of the micA gene in Clavibacter michiganensis subsp. michiganensis, 1220

photocatalytic nanoscale formulations of titanium dioxide in control of Xanthomonas

perforans, 228

Pseudomonas syringae pv. syringae differentiated phylotype associated with mango, 1115 genetic and phylogenetic diversity of strains from pea, 673 
Bacteriophage

ecological niches and coevolution with

Xanthomonas arboricola pv. pruni on peach

trees, S2.135

phage seed treatments, S2.174

phage therapy for horse chestnut bleeding canker, S2.67

therapeutic and prophylactic application for

Pierce's disease, S2.34

transmission by glassy-winged sharpshooters, $\mathrm{S} 2.16$

Badillo-Vargas, I. E., S3.2

Bagi, F., S2.21, S2.102

Bailey, D. J., 1012

Baird, R. E., S1.10, S2.139

Baird, S. M., S2.35

Bais, H. P., S2.90

Bai, Y., 623

Baker, S. E., 400

Balansia epichloe, additional hosts in tall fescue pastures, S2.11

Balci, Y., 1204, S2.60, S2.191, S4.2

Baldwin, B. S., S1.4, S2.49

Baldwin, T. T., S2.11

Balint-Kurti, P., S4.3

Ball, B., S2.150

Ballistosporic phylloplane yeast survey, S2.4

Baltrus, D. A., S2.8, S2.48, S2.130

Bamboo, metabolic effects of AP-toxin, 135

Bambusa pervariabilis $\times$ Dendrocalamoisis

grandis blight, 135

Banana bunchy top disease (BBTD), S2.103

Bandara, A. Y., S2.11, S3.2

Bandla, P., S2.1

Bandyopadhyay, R., S2.5, S2.70, S3.13

Banihashemi, Z., S2.97

Bao, Y., 1162

Barak, J., S2.56, S2.185

Barak, J. D., S2.171

Barandoc-Alviar, K., S2.11

Baraoidan, M., S2.89

Barash, I., S2.24

Barbeau, A. D., S3.5

Barbetti, M. J., S2.53

Bardsley, S., S2.11, S2.173

Bargeron, C., S2.28

Barker, G., S3.13

Barley (Hordeum vulgare)

association mapping of Septoria speckled leaf blotch resistance in breeding germplasm, 600

brassinosteroid enhancement of resistance to Fusarium diseases, 1260

epidemics of stripe rust and races of Puccinia striiformis identified in the U.S. in 2012 , S2.155

evaluation for Xanthomonas translucens pv. undulosa resistance, $\mathrm{S} 2.127$

genetic variation in Cochliobolus sativus isolates, $\mathrm{S} 2.78$

identification of Rhizoctonia root rot

resistance in, $\mathrm{S} 2.3$

quantitative resistance to Fusarium head blight, 1252

temporal evaluations on the wheat stem rust infection process on, S3.9

Barley yellow dwarf virus (BYDV), S3.1

Barman, A., S2.137

Barnes, C. W., S2.11, S2.12, S2.108

Baroni, T., S2.53

Barphagha, I. K., S1.7, S1.8, S2.192

Barrerra, M. D., S2.153

Barreto, S. S., 436

Barry, K., S2.181

Barsoum, N., S2.181

Bartholomay, T., S2.190

Bartlett, B., 1180

Bartlett, J., S2.150

Bartlett, P. B., S2.25
Bartnicki-García, S., S2.118

Bartz, J. A., S2.12

Basidiomycetes, comparative analysis of 35

genomes, S2.121

Basidiomycota Consortium, S2.121

Basil downy mildew control with acibenzolar- $S$-methyl, S2.95 effect of plant age on, S2.111 incubation and latent periods, S3.6 management by seed treatment with oxathiapiprolin, S2.111

Basu, D., 841

Bateman, C., S2.71

Bateman, H. L., S2.140

Bateman, M., S2.116

Bates, A., 1012

Bates, S., S2.144

Batrachochytrium dendrobatidis, S2.15, S2.67

Battista, L. J., S2.126

Batuman, O., S2.12

Batzer, J., S2.12

Batzer, J. C., 900, S2.65, S2.66, S2.83, S2.166

Bauchan, G., S2.67

Bauchan, G. R., S2.18

Baucom, D., S2.12

Baudoin, A., S2.12, S4.1

Baufumé, S., S2.13

Baumgartner, K., S2.13, S2.63, S2.148

Baum, T. J., 175, S2.129

Bautista-Jalon, L. D., S2.68

Bayoud disease, S2.125

Baysal-Gurel, F., S2.13

bcsA gene, 362

Beacham, J., S2.136

Bean common mosaic virus (BCMV), S2.42, S3.13

Beard, C. E., S2.13

Beattie, M., S2.7

Beauveria bassiana, S2.84

Beauveria bassiana ATCC 74040, 1001

Becerra, V., S2.45

Becker, L., S2.14

Beckerman, J., S2.79

Bec, S., S2.13

Beech bark disease (BBD), S2.23, S2.125

Beem, L. W., S2.159

Beet leafhopper, S2.31

Beet severe curly top virus (BSCTV), S2.139,

S3.15

Begerow, D., S2.13

Begomoviruses

association of a monopartite begomovirus with okra leaf curl disease, S2.5

inadvertent selection of resistance-breaking begomoviruses, S2.179

infection of Gold Veined Oxalis, S2.59

survey tools, S2.120

weeds as potential inoculum sources for a tomato-infecting virus, 436

Behlau, F., 409

Behrens, T., S2.158

Behringer, G., S2.14

Beirn, L. A., S2.14, S4.1

Bejarano, J., S2.14

Bekoscke, K. A., S2.14

Belasque, J., S2.50

Belausov, E., 362

Belisario, A., 802

Bell, A. A., S2.31

Bell pepper. See Capsicum annuum; Pepper

Belonolaimus longicaudatus, S2.131

Belton, M., S2.124

Bemisia tabaci biotypes, $\mathrm{S} 2.7$

Benitez, M. S., S2.14, S2.35

Bennett, J. W., S2.63, S2.78, S2.99

Benson, D. M., S1.7, S2.47

Bent, A., S2.121

Benzamide, pre- and postharvest management of citrus brown rot, S2.3
Benzimidazole, sensitivity of Cercospora beticola to, $\mathrm{S} 2.21$

Berbee, M. L., S2.19

Berbegal, M., 851

Berberis brachypoda, 927

Berberis shensiana, 927

Berberis soulieana, 927

Berberis spp.

identification as alternate hosts of Puccinia striiformis $\mathrm{f}$. $\mathrm{sp}$. tritici, 927

infection by Edythea quitensis, S2.12

Bereman, M. S., S2.65

Berg, A., S2.63

Bergemann, S. E., S2.63, S2.71

Bergeron, M. J., S2.143

Bergsträsser, S., S2.128

Bergstrom, G. C., 146

Berlin, A., S2.181

Bermudagrass (Cynodon dactylon), evaluation of fertility and fungicide programs on foliar diseases, S2.112

Berner, D. K., 708, S2.15, S2.18, S4.1

Berthold, F., S2.188

Beseli, A., S2.15

Besler, K., S2.15

Bester, C., S2.75

Betancourt-Resendes, I., S2.15, S2.136

Betancourt-Román, C. M., S2.15, S2.67

Beta vulgaris. See Sugar beet

Beukes, I., S2.72

Bextine, B., S2.177

Beyer, M., S2.38

Bezerra, J. L., S2.122

Bhardwaj, M., S2.109

Bhattacharya, D., S2.173

Bhattacharyya, M. K., 400

Bhowmick, T. S., S2.16, S2.34

Bidartondo, M., S2.181

Biedrzycki, M. L., S4.3

Bienapfl, J., S2.179

Bilodeau, G. J., 43, S2.32, S2.76

Bimolecular fluorescence complementation, S2.148

Binder, M., S2.16, S2.104

Bindweeds, S4.1

Bing, Y., S2.167

bin Salleh, B., 400

Binucleate Rhizoctonia, spread potential during

vegetative propagation, S2.30

Biochemistry and cell biology

AP-toxin from Arthrinium phaeospermum, purification and metabolic effects on bamboo, 135

glyceollin in soybean defense against Phytophthora sojae and Macrophomina phaseolina, 984

hydrogen peroxide accumulation and transcriptional changes in grapevines recovered from Flavescene dorée disease, 776

Biocontrol agents

field performance of Aspergillus flavus AF36 in cotton, $\mathrm{S} 3.13$

modeling study in the control of foliar pathogens, 108

Phoma macrostoma var. macrostoma as a potential control agent of field and hedge bindweed, S4.1 synergy from the combined use of, 768

Bioenergy grass. See Switchgrass

Biofumigation, management of Phytophthora blight, S2.93

Biofungicides, suppression of clubroot on canola by Serenade, 245

Bioinformatics, strategies for microbial forensics, S2.176

Biological control abiotic stresses affect Trichoderma harzianum T39-induced resistance to grapevine downy mildew, 1227 
of bacterial blight of anthurium, S2.6 of Canada thistle, S2.15

effect of biological control agents on strawberry leaf microbiota, 1001

effect of pathogen variation and urea on

Streptomyces mixtures, 34

of Fusarium head blight of wheat by Bacillus amyloliquefaciens, 146

of Fusarium oxysporum, S2.14

host-specific control of grape crown gall by Agrobacterium vitis strain F2/5, 427

phenazine production by Pseudomonas sp.

LBUM223, 995

of Phytophthora and Verticillium wilts in chile pepper, S2.56

of Phytophthora nicotianae, S2.56

root disease suppression in response to

compost water extract, 255

soil suppressiveness to Fusarium disease, 23

suppression of clubroot on canola by

Serenade, 245

Trichoderma control of soilborne pathogens, $\mathrm{S} 2.42$

Bioluminescence, in Armillaria, S2.96

Biopesticides, S2.109, S2.175

Biorational products, evaluation for efficacy

against fungal pathogens of Valencia peanut, S3.16

Biosecurity

masters-level education, S2.189

next generation sequencing and, S2.33

recent innovations, $\mathrm{S} 2.176$

Biotrophic interfacial complexes (BICs), S2.186

Bipolaris, $\mathrm{S} 2.89$

Bi, Q., 641

Bishop, B. A., S2.189

Bitternut hickory (Carya cordiformis),

Ceratocystis smalleyi infections reduce sap flow in, 565

Bittleston, L. S., S2.16

Bi, Y., 920

Black Aspergillus, S2.175

Black, A. W., S2.71

Blackberry, a new marafivirus in yellow vein

disease-affected plants, S2.87

Blackberry cane blight, management, S4.3

Blackberry viruses, incidence in the U.S., S1.6

Blackcurrant, Cronartium ribicola on, S2.143

Black dot, factors affecting development in

storage, S2.161

Black, M., S1.7, S2.126

Black pepper, fusariosis, S2.113

Black root rot of strawberry, S2.147

Black rot in cabbage, evaluation of control, S2.76

Black spot disease, 841

Black Turtle Soup common bean, S2.73

Black walnut (Juglans nigra), fungi isolated from

ambrosia beetles, S2.120

Blackwell, M., S2.150

Blackwell, W. H., S2.115

Blacutt, A., S2.16

Blagden, T., S2.33, S2.176

Blair, J. E., S2.28, S2.178

Blair, M. W., 156

Blakeslee, J. J., S2.26

Blancaflor, E., S2.92

Blanchette, R. A., S2.11, S2.95, S2.121, S2.180

Blanco-Meneses, M., S2.16

Blanco-Zapata, D. C., S2.17

Blanvillain, S., S2.170

Blasioli, K., S2.82

Blastocladiomycota, S2.68

Block, C., S2.17

Blow flies, S2.185

Blueberry (Vaccinium spp.)

Blueberry shock virus sampling efficiency and cold hardiness studies, S2.127 comparing the effects of Xylella fastidiosa subspp. multiplex and fastidiosa, S2.107 control of gray mold with compost tea, S2.20 effects of environmental factors on infection by Colletotrichum acutatum, S2.127

morphogenetic diversity of Chondrostereum purpureum isolates, $\mathrm{S} 2.45$

stem blights and root rots in Mexico, S2.119

Blueberry shock virus (B1ShV), S2.127

Blueberry silverleaf, S2.45

Blue grama grass (Bouteloua gracilis), S2.115

Blue mold, host range of rotting bulb crops, S2.37

Blue mold resistance

Malus sieversii, S2.67

to postharvest fungicides, S2.70

Bluhm, B. H., 1045, S1.9, S2.42, S2.60, S2.101,

S2.120, S2.121, S2.127

Blumeriella jaapii, S2.191

Boal, R. J., S2.163

Boccacci, P., 776

Boch, J., S2.13, S2.170

Bock, C. H., S2.17

Bockus, W. W., 74, S3.1

Bocsanczy, A. M., S2.17, S2.18

Boehm, M. J., S2.14, S2.127, S4.1

Bogar, L., S2.182

Bogdanove, A. J., S2.171

Bois noir $(\mathrm{BN})$, field treatment with resistance inducers, 785

Boiteux, L. S., S2.127

Boiteux, M. M. E., S2.127

Bóka, K., 623

Bokati, D., S2.18

Bokhari, S. S., S2.18

Boland, G., S2.111

Boletineae, S2.104

Bolot, S., S2.170

Bombecini, J., S2.10

Bonants, P., 1169

Bonas, U., S2.187

Bonato, A. L. V., S3.5

Bonde, M. R., 708, S2.18

Bond, J., S2.157

Bond, J. P., S2.101, S2.158

Bonello, P., S2.24, S2.29, S2.132

Bonito, G., S1.2, S2.18, S2.58, S2.135

Bonning, B. C., S3.2

Booher, N. J., S2.171

Booth, C., S1.3, S2.37

Bordeos, A., S2.89

Borderick, K., S3.3

Bordiya, Y., S2.19, S2.70

Boreal endophytes, genomic comparison, S2.161

Borejsza-Wysocka, E., S2.31

Boro, M. C., S2.153

Borowicz, P., S2.37, S3.3

Borrego, E. J., S2.19

Boscalid, field selection of DMI insensitive

Sclerotinia homoeocarpa isolates, S2.5

Boscalid resistance

in Alternaria spp. in the Colombia Basin, S3.17

in Botrytis cinerea from eastern U.S. vineyards, S4.1

detection in Blumeriella jaapii, S2.191

Bose, T., S2.19

Bosland, P. W., 472

Bossa-Castro, A. M., S2.19

Bostock, R. M., S2.84, S2.122, S2.124, S2.163

Boston Harbor Islands, S2.54

Botha, A. M., S2.87

Botryosphaeriaceae

among temperate nut crops in California, S3.14

associated with almond trunk cankers, S3.12 tropical fruit diseases in Puerto Rico, S3.16

Botryosphaeria dieback control with Glomus intraradices and Trichoderma spp., S2.103 defining the stages of infection in grapevines, $\mathrm{S} 2.13$

See also Neofusicoccum parvum
Botrytis, evaluation of fungicide applications in strawberry fields, S2.112

Botrytis cinerea

biocontrol

with compost tea in blueberry, S2.20

effect of biological control agents on strawberry leaf microbiota, 1001 with phillospheric yeasts on cut roses, S2.85

effect of host nitrogen nutrition on secondary inoculum, 261

effect of quinolone alkaloids on, S2.68

fungicide resistance monitoring for in strawberry, $\mathrm{S} 2.43$ prevalence and characterization in isolates from small fruits, S2.51

QoI and boscalid resistance in eastern U.S. vineyards, S4.1 survey of vineyards in Virginia, S2.12

role of nursery plants as a potential source of inoculum, S2.107

in vitro evaluation of endophytic fungi antagonists, S2.122

See also Gray mold

Bottle gourd (Lagenaria siceraria), S2.75

Bottner-Parker, K. D., S2.26

Boucher, C., S2.64

Bourdot, G., S2.15

Boureau, T., S2.170

Bousquet, A., S2.63

Bouteloua gracilis. See Blue grama grass

Bowen, K. L., S2.19, S2.23, S2.54, S2.79

Bowman, H. M., S2.20

Bowman, L., S2.187

Boxwood blight

molecular diagnostics for early detection, S2.90 population genomic RAD-Seq

characterization of, $\mathrm{S} 2.58$

sanitizing agents in management, S2.36

significance of soil inoculum in the epidemiology of, $\mathrm{S} 2.33$

susceptibility of commercial boxwood cultivars to, S2.47

Boyer, R. R., S2.120

Boyetchko, S. M., 245

Boyzo-Marin, J., S2.119, S2.134

Brachypodium distachyon, S2.88

Bracket fungi, improved taxonomic resolution,

S2.96

Bradeen, J., S2.20

Bradley, C. A., S2.3, S2.88, S2.94, S2.123,

S2.127, S2.131, S2.166, S2.175, S3.6

Bradshaw, J. D., 1235, S2.162

Bradshaw, R. E., 725

Bradyrhizobiurm japonicum, S3.8

Bragança, C. A. D., S2.104

Branco, S. D., S2.82

Brandl, M. T., 304, 316, 362

Brandt, M. E., 400

Brannen, P. M., S2.20, S2.104

Brannon, J. M., S2.107

Brar, S., S2.143

Brassicaceae

influence of phenological status on the antifungal constituents of, S2.151

seed meal amendments, S2.92

Brassica germplasm, field screening for resistance against white leaf spot disease, S2.53

Brassica juncea, 841, S1.5

Brassica napus. See Canola

Brassinosteroids, 1260

Brazee, N. J., S2.20

Breiland, M., S3.2

Brem, R., S2.186

Brenneman, T. B., S1.2, S1.5, S1.10, S2.17,

$\mathrm{S} 2.135, \mathrm{~S} 2.149, \mathrm{~S} 3.12$

Breth, D., S2.31

Brevipalpus phoenicis (false spider mite), 488

Brewer, M. T., 717, S2.14, S2.178 
Briceño, E. X., S2.20

Bridges, W. C., S2.131

Briere, S., S2.76

Bright, D. B., S2.69

Brin, C., S2.170

Brlansky, R. H., 488, S2.62, S2.124, S2.165

Broad-spectrum rust resistance, simple sequence repeat DNA markers linked with in common bean, S2.132

Broccoli, effect of HYT A and HYT B on fungal pathogen growth, S3.12

Brockhurst, M., S2.67

Broders, K., S2.82, S2.111

Bromus laevipes, $\mathrm{S} 2.55$

Bronze leaf disease of Populus, S2.108

Brown, D. W., 400

Browne, G. T., S2.128

Brown, J. K., S2.7, S2.44, S2.120, S2.179

Brown, P., S2.24

Brown patch

development of SCAR markers and UP-PCR cross-hybridization method for detection, S2.76

effect of mowing height on severity in tall fescue, S3.9

Brown, R. L., S1.2, S1.4, S2.45

Brown root rot, dissemination pattern in Taiwan, $\mathrm{S} 2.28$

Brown rot

multi-drug resistance to site-specific

fungicides, S2.55

spatial assessment of oxidative and enzymatic reactions in brown rotted wood, S2.95

Brown rust

of sugarcane, history in Florida, S2.29

See also Puccinia melanocephala

Brown, S., S2.182

Brown, S. P., S2.20, S2.86, S2.107

Brueggeman, R., 1153, S2.21, S2.37, S2.74, S3.3, S3.9

Brunings, A. M., S2.134

Bruns, T., S2.21

Bruns, T. D., S2.82, S2.182

Bryan, N., S1.2

Bryone, F., 261

Bryson, P. K., S2.43

Buchanan, A., S2.28

Buchanan, R. L., S2.89

Buchloë dactyloides (buffalograss), S3.1

Buchman, J. L., S2.130

Buck, J. W., S2.151

Buckley, B., S2.120

Budakov, D., S2.21, S2.102

Buehring, N., S1.1

Buell, R., S2.117

Buffalograss (Buchloë dactyloides), S3.1

Buffalograss false smut, S3.1

Buitrago, C., S2.106

Bui, V., S2.79

Buk, J., S2.155

Bull, C. T., S2.21

Bullock, R. W., S2.70

Bulyonkova, T., S2.70

Bunyaviridae, $\mathrm{S} 2.110$

Burbank, L., S2.21

Burchhardt, K. M., S2.21

Burdman, S., 362

Burgess, L. W., 400

Burgess, T., 1204

Burgos, M. R. G., S2.152

Burke, S., S1.2

Burkholderia contaminans strain MS14, S2.35

Burkholderia gladioli pv. allicola, S2.173

Burkholderia glumae

DSF-mediated signaling system in, S1.2

LAMP detection of, S2.23

negative regulatory function of $n t p R$ for virulence, $\mathrm{S} 1.7$ negative regulatory gene for toxoflavin production, S2.192

regulatory and signaling network for the virulence of, $\mathrm{S} 1.5$

role of tepR in toxoflavin production and virulence, $\mathrm{S} 1.8$

virulence deficiencies associated with

mutation of aroA and $a r o B$ genes, S1.6

See also Bacterial panicle blight of rice

Burnett, F. J., 1108

Burns, D., S1.5

Burrack, H., S1.6

Burris, E., S1.5

Burrows, M., S2.22, S2.97

Burr, T., 427, 633, S2.69

Butler, D., S2.61

Butternut (Juglans cinerea), S2.66

Butternut canker, S2.66

Byamukama, E., S2.143

Bymovirus, 949

Cabbage, evaluation of control of black rot, S2.76

Cabrera, A., S2.7, S2.33

Cacao, frosty pod rot, S2.35

Cacciola, S. O., 610

Cadang-Cadang disease, S2.177

Cadieux, M., S2.147

Cadle-Davidson, L., 717, S2.14, S2.22, S2.93

Caffi, T., 64

Caiazzo, R., S2.22

Cai, G., S2.100, S2.173

Calcium signal modifier (CSM-1) gene, S2.86, S2.152

Caldera Dominguez, M. A., S2.23

Calder, B. L., S2.8

Calderón-Zavala, G., S2.39

Cale, J. A., S2.23

Callaham, M., S2.107

Callicott, K., S2.5, S2.105, S2.108

Calonectria pseudonaviculata molecular diagnostics for early detection, S2.90

population genomic RAD-Seq

characterization of, S2.58

sanitizing agents in management, S2.36

significance of soil inoculum in the epidemiology of, S2.33

Calystegia sepium, $\mathrm{S} 4.1$

Cambra, M., 972

Camellia flower blight, 725

Camellia lutchuensis, 725

Camellia spp., induced host resistance by

Cibornia camelliae, 725

Caminero, C., 673

Campbell, A., S2.114

Campbell, A. J., S2.23

Campbell, E., 333

Campbell, H. L., S2.23

Campbell, K. G., S2.3

Campbell-Nelson, K., S2.5

Campbell, P. R., S2.71

Campe, R., S2.77

Campillo, T., S2.87

Canada thistle (Cirsium arvense), S2.15

CANARY technology, S2.20

'Candidatus Liberibacter asiaticus'

characterization of Sec-translocon-dependent extracytoplasmic proteins, S2.157 development and application of scFV for, S2.165

development of a home detection kit for, S2.72

estimation of populations in Texas citrus trees, S2.75

Flg22-triggered defense responses in mandarin and grapefruit, S2.132

heat treatment, 15

induction of lytic cycle genes, S2.44

live bacterial population dynamics, S2.62 research review, 652

transcriptome analysis of 'Valencia' sweet

orange response to, $\mathrm{S} 2.86$

visualization of cells in citrus seed coat

vascular bundles, 545

See also Citrus huanglongbing;

Huanglongbing

'Candidatus Liberibacter' interactors, website for

the identification of, S2.44

'Candidatus Liberibacter psyllaurous', S2.72

'Candidatus Liberibacter solanacearum'

advances in the detection of, S2.79

assessment of management and environmental

factors affecting regional occurrence, S2.162

development of a haplotyping assay, S2.159

effect on tuber physiology, 419

functional characterization of virulence genes, S2.125

hypervariable phage-like regions, S2.69

influence of environmental factors and management practices on occurrence, 1235

overview, characterization, and discussion of management, 524

potato volunteers as a source of, $\mathrm{S} 2.38$

relationship of potato biochemical responses

to disease progression, $\mathrm{S} 2.154$

titer over time in Bactericera cockerelli,

$\mathrm{S} 2.130$

transcriptomic, proteomic, and nutritional analyses of potato tissues infected with, $\mathrm{S} 2.104$

See also Potato zebra chip disease

'Candidatus Phytoplasma asteris', S2.27

'Candidatus Phytoplasma pruni', S4.1

Candresse, T., 293, 972

Cannon, P. F., S2.33

Cannon, P. G., S2.123

Canola (Brassica napus)

detection of 'Candidatus Phytoplasma asteris', S2.27

genetic and phenotypic diversity in Sclerotinia sclerotiorum populations infecting, 750 suppression of clubroot by Serenade, 245

Canopy reflectance, anthracnose severity on annual bluegrass and, S2.65

Cantaloupe, regulatory effect of soli matric water potentials on a tripartite host-specific

rhizosphere interaction, S2.138

Cantharellaceae, S2.58

Cantharocybe brunneovelutina, S2.28

Cantilina, K., 1180

Cantu, A., S2.23

Cantu, M., S2.91

Cao, J., S2.85

Cape gooseberry (Physalis peruviana), S2.14

Capelari, M., S2.71

Capello-García, S., S2.152

Capik, J. M., S2.100

Caplan, J., S4.3

Capnondiales, S2.19

Cappello, S., S2.28

Capsicum annuиm

metabolomic analysis of non-host pathogen induced resistance in, $\mathrm{S} 2.138$

novel gene inhibiting host-specific resistance to Phytophthora capsici, 472

QTL mapping of Phytophthora fruit rot resistance, $\mathrm{S} 2.101$

See also Chile pepper; Pepper

Capsicum spp., Phytophthora fruit rot resistance, S2.101

Carballo, V., S2.155

Carbohydrate utilization (CUT) systems, S2.170

Carbonaro, D., S2.120

Carbone, I., S1.8, S2.14, S2.79, S2.106, S2.116, S2.145, S2.150, S2.161, S4.1

Carboxylic acid amide, pre- and postharvest

management of citrus brown rot, S2.3

Cárdenas, M., S2.23 
Cardendeazim resistance, mechanisms and management in Gibberella zeae, S2.184

Carica papaya. See Papaya

Carlaviruses, S2.72

Carlsward, B. S., S2.128

Carnago, G., S2.52

Carpane, P., 129

Carrère, S., S2.170

Carrillo, D., S2.71, S2.114

Carrillo-Fasio, J. A., S3.11

Carrión, V. J., 1115

Carrise, O., 811, 1087

Carris, L. M., S2.93

Carroll, A., S2.51

Carrot foliar disease control, S3.5

Carter, M., S2.179

Carter, P. A., 750

Cartwright, R. D., S2.24

Caruso, F. L., S2.109, S2.136

Carvajal Yepes, M., S3.8

Carya cordiformis (bitternut hickory), 565

Carya ovata (shagbark hickory), 565

Cary, J., S2.127

Caseinolytic protease genes, 427

Castagnaro, A. P., 555

Castañeda-Ruiz, R. F., S2.52

Castello, J. D., S2.23

Castlebury, L. A., S2.89, S2.91, S2.93, S2.134, S2.150

Castroagudin, V. L., S2.24

Castro-Beltran, G., S2.112

Castro, P. R. D. C., S2.174

Casuarina equisetifolia decline, S2.10, S2.128

Catalano, V., 802

Catal, M., 190

Catani, D. H. P., S2.50

Catharanthus roseus (annual vinca), S2.155

Cattan, N. C., S2.100

Cauliflower mosaic virus (CaMV)

P6 inclusion bodies, S2.122

P6 protein and the delivery of virions to plasmodesmata, S2.188

role of CHUP1 and class XI myosins during infections, S2.7

Caulimo-like virus, S2.1

Cavender-Bares, J., 565, S2.41

Cavin, C. A., S2.15, S4.1

Cazorla, F. M., 1115

Cech, N., S2.105

Celio, G. J., S2.93

Cellier, G., S2.3

Cellular telemetry, S2.8

Center rot of onion, S2.173

Ceratobasidium root rot of watermelon, S2.103

Ceratocystis fimbriata

genetic variability in isolates from mango, S2.107

hypervariable ITS sequences among isolates, S2.56

impact of salinity on wilt in mango, S2.100

impact on mango seedling growth, S2.137 wilt disease on kiwifruit in Brazil, S2.43

Ceratocystis smalleyi, reduction of sap flow in

bitternut hickory, 565

Ceratocystis wilt of kiwifruit, S2.43

Cercospora arachidicola, S1.8

Cercospora beticola, sensitivity to benzimidazole

and sterol demethylation inhibiting fungicides, $\mathrm{S} 2.21$

Cercospora janseana

effect of amended media, temperature, and light on growth and development, S2.71

efficacy of Bacillus in biocontrol with organic rice, $\mathrm{S} 2.168$

role of amino acids, vitamins, and inorganic salts in the development of, S1.6

Cercospora kikuchii

effects of minor elements on, S1.11, S2.158

field screening soybeans for, S2.120 fungicide resistance, $\mathrm{S} 2.116$

fungicide sensitivity, S1.9

Cercospora leaf blight of soybean

effects of minor elements on, S1.11, S2.158

field screening for resistance, S2.120

See also Cercospora kikuchii

Cercospora-resistant sugar beet, S2.128

Cercospora seminalis, $\mathrm{S} 3.1$

Cercospora sojina

characterization and molecular diagnosis of

QoI resistance, S2.166

epidemiology and population diversity,

S2.165

mating-type distributions and genetic diversity

on soybean, 1045

Cercospora spp., hypothetical proteins in

resistance to cercosporin, $\mathrm{S} 2.15$

Cercospora zeae-maydis, circadian regulation of

pathogenicity in, $\mathrm{S} 2.60$

Cercosporidium personatum, $\mathrm{S} 1.8$

Cercosporin, S2.15

Cereal grain domestication, root-associated fungal

communities and, S2.18

Ceresini, P. C., 862, S3.5

Cevallos-Cevallos, J. M., 381

Chabot, D., S2.103

Chai, Y., S3.2

Chakraborty, S., S2.24

Chaky, J. L., S3.3

Chalupowicz, L., S2.24

Chambergo, F. S., S2.34

Chamorro, M., S2.95, S2.130

Chang, J. H., S2.28

Chang, S., S2.24

Chang, T., S2.63, S2.126

Chan, K., S2.180

Chansler, M. T., 1280

Chao, C. T., S2.67

Chao, S., S3.2

Chapara, V., S2.166

Chapman, S., 333

Chappelka, A. H., S2.26

Charbit, E., S2.170

Charcoal rot. See Macrophomina phaseolina

Charcoal rot resistance, evaluation of soybean

varieties for, $\mathrm{S} 2.130$

Charkowski, A. O., S2.25, S2.46

Charlton, N. D., S2.55, S2.133, S2.165

Chase, T., S2.123

Chase, T. E., S2.25

Chastagner, G. A., S2.37, S3.12

Chatnaparat, T., S2.25

Chatterjee, M., 841

Chaudhury, A., S2.25

Chavan, S., S2.25

Chaverri, P., S2.59, S2.90, S2.125, S2.134

Che, G.-N., 135

Chellemi, D. O., 792

Chen, C., S2.184

Chen, C. Y., S2.82

Chen, F., S2.128

Cheng, M., S2.26

Cheng, Q., S4.2

Cheng, T.-F., 888

Cheng, Z., 594, S2.184

Chen, J., S2.154, S2.157

Chen, J.-P., 949

Chen, K. C., S2.35

Chen, K. H., S2.26

Chen, L., S2.165

Chenopodium quinoa. See Quinoa

Chen, P., S2.80

Chen, R., S1.2, S2.84

Chen, S., S3.14

Chen, W., 43, 750, 927, S2.178

Chen, X., S2.42, S2.155, S2.156, S2.164, S2.184

Chen, X. M., 927

Chen, Y.-C., 888

Chen, Z., S1.2, S1.4
Chen, Z. Y., S2.45, S2.120

Cheong, K., 1204

Cherry, viruses associated with rusty mottle and twisted leaf diseases, 1287

Cherry green ring mottle virus (CGRMV), 1287

Cherry leaf spot (CLS), S2.191

Cherry necrotic rusty mottle virus (CNRMV), 1287

Cherry rusty mottle disease, 1287

Cherry twisted leaf disease, 1287

Chestnut blight, 1280

Cheung, H. Y., S2.26

'Chevron' spring barley, 1252

Chewachong, G. M., S2.26

Chiampiriyakul, P., S2.26

Chieppa, J., S2.26

Chiesa, M. A., 555

Chile pepper

biocontrol agents for Phytophthora and

Verticillium wilts, S2.56

effect of Chlorella on Phytophthora blight, S3.16

metabolomic analysis of non-host pathogen induced resistance in, $\mathrm{S} 2.138$

novel gene inhibiting host-specific resistance to Phytophthora capsici, 472

Verticillium dahliae peduncular infection and seed transmission, S3.14

See also Capsicum annuиm

Chilumpha, E., S2.104

Chilvers, M. I., S2.123, S2.150, S2.157

'Chinese Spring' wheat cultivar, 575

Chitin synthase gene, S2.108

Chitrampalam, P., S2.27, S2.103, S2.107

Chittem, K., S2.27

Chlorella, S3.16

Chloroplasts, in the local and systemic movement of Alphaflexiviridae, $\mathrm{S} 2.188$

Choi, H. W., S2.19

Choi, J., 1204

Choi, K., S2.27

Chondrostereum purpureum, S2.45

Choudhary, N., 488, S2.124

Choudhury, R. A., S2.27

Christner, B., S1.2

Chrysanthemum white rot, S2.18

Chrysanthemum white rust, 1169

Chrysolepis chrysophylla, S2.85

Chukeatirote, E., S2.89, S2.150

Chulze, S., 400

Chuma, I., 575

Chung, C. L., S2.28, S2.82

CHUP1 myosins, S2.7

Chu, R., 1162

Chu, Y., S1.9

Chytridiales, S2.130

Chytridiomycosis, S2.15, S2.67

Chytridiomycota, S2.68

Chytrids, S2.34, S2.115

Ciborinia camelliae, 725

Cichorium intybus, $\mathrm{S} 2.112$

Cifuentes, J., S2.28, S2.63

Cilevirus, 488

Cilia, M., S2.65, S2.87, S2.103

Ciomperlik, M., S3.15

Ciotola, M., S2.147

Circulifer tenellus, S2.31

Cirsium arvense. See Canada thistle

Citron melon, survival and seed transmission of Acidovorax citrulli, S2.37

Citrullus lanatus. See Watermelon

Citrullus lanatus var. citroides, S2.37

Citrus

'Candidatus Liberibacter asiaticus'

heat treatment, 15

visualization of cells in seed coat vascular bundles, 545

characterization of a Xanthomonas citri subsp. citri variant triggering a host-specific disease response, 555 
evaluation of HLB tolerance, S2.118

mechanism of Xanthomonas citri avirulence

factor AvrGf1 in inducing hypersensitive

response in, S2.168

Phytophthora nicotianae re-emerging in

Florida citrus groves, S2.36

prevalence of diseases in Puerto Rico,

S2.191

root-shoot dichotomy in citrus-Citrus tristeza virus, $\mathrm{S} 2.56$

seasonal dynamics and correlation studies of viroids, $\mathrm{S} 2.82$

temperature/wetness modeling of Guignardia pseudothecium maturation and ascospore release, 281

use of very young plants for biological indexing of graft transmissible pathogens, S3.14

Citrus-associated Xanthomonas, acquisition of copper resistance genes from different sources, 409

Citrus aurantifolia, 555

Citrus black rot/spot

characterization and potential spread in the U.S., S2.40

See also Guignardia citricarpa

Citrus brown rot, pre- and postharvest

management, S2.3

Citrus brown spot, 741

Citrus canker

comparison of culture and bioassay for detection of, S2.17

control with trunk and soil applications of

neo-nicotinoid insecticides, $\mathrm{S} 2.52$

convergence of TAL effectors on a single host susceptibility gene, S2.62

evaluation of Citrus sinensis for resistance to, S2.50

See also Xanthomonas citri pv. citri

Citrus clementina, 555

Citrus exocortis viroid (CEVd), S2.82

Citrus greening (CG), prevalence in Puerto Rico,

S2.191

Citrus huanglongbing (HLB)

assessment in Dominica, S2.141

research review, 652

transcriptome analysis of 'Valencia' sweet

orange response to, $\mathrm{S} 2.86$

See also 'Candidatus Liberibacter asiaticus';

Huanglongbing

Citrus leprosis, 488

Citrus leprosis cytoplasmic type 2 (CiLV-C2), 488

Citrus leprosis virus (CiLV-C), 488, S2.124

Citrus limon, 555

Citrus paradisi, 555

Citrus root rot, 610

Citrus sinensis, evaluation for resistance to citrus

canker, S2.50

Citrus tristeza virus (CTV)

molecular diversity in California, S2.156

prevalence in Puerto Rico, S2.191

root-shoot dichotomy in citrus-CTV

interactions, $\mathrm{S} 2.56$

seedling yellow symptom induction changes

microRNA expressions, S2.56

stability in populations in field and glasshouse sweet orange, S2.31

Citrus variegated chlorosis (CVC), S2.191

Citrus vein enation, 1077

Citrus vein enation virus (CVEV), 1077

Civitas, S1.8

Clark, C. A., S2.142

Clarke, B., S2.14

Clarke, B. B., S4.1

Clarke, E., S2.124

Clarke, H. D., S2.150

Clark, J. S., S2.14

Class XI myosins, S2.7
Clavibacter michiganensis subsp. michiganensis loop-mediated amplification of the micA gene, 1220

tomato fruit colonization, S2.143

Clavibacter michiganensis subsp. nebraskensis differences in corn hybrid structural responses to, $\mathrm{S} 2.93$

effect of residue management practices, S2.94

within field spatial and temporal analysis, S2.35 greenhouse corn hybrid responses to, S3.6 See also Goss's wilt and leaf blight of corn

Clavibacter michiganensis subsp. sepedonicus,

S2.87

Claviceps purpurea, spatial patterns in Kentucky

bluegrass and perennial ryegrass grown for seed, S2.37

Claytonia virginica (spring beauty), S2.128

Clean plant centers, S2.179

Clement, D. L., S2.28

Clerc, P., S2.149

Clifford, J., S2.28, S2.119

Climate change

responses of plant-symbiotic fungi to, S2.182 uncertainty and agricultural decision making under, S2.59

Clonostachys rosea ACM941, S2.87

clpA gene, 427

clpP1 gene, 427

Clubroot

suppression by Serenade, 245

See also Plasmodiophora brassicae

Cluskey, S. A., S3.15

Cluster bean, detection of Macrophominia

phaseolina with SCAR assay, S2.25

Clustered Regularly Interspaced Short

Palindromic Repeats (CRISPR) systems, S2.67

Cluzer, S., 1028

Coastal dune grasses, effects of environment and

host on endophyte communities, S2.34

Coast live oak (Quercus agrifolia), S2.29

Coat proteins, S2.143

Coats, K., S2.82, S3.12

Cobian, G., S2.70

Cobine, P. A., S2.107

Coccoloba lianas, S2.150

Cochliobolus sativus, $\mathrm{S} 2.78$

Cochran, A. M., S2.94

Cochran, K., S1.2

Cochran, K. A., S2.28

Coemansia reversa, $\mathrm{S} 2.93$

Coenosia tigrina, S2.53

Coffee rust, plant nutrition and, S2.151

Coffey, M. D., 43, 610, 1204, S2.91

Coffua, L. S., S2.28

Cold storage, identification of Salmonella

enterica genes with a role in persistence on

lettuce leaves during, 362

Coleman, J. J., 400

Colletotrichum acutatum

distribution and host range on Salicaceae, S2.142

effect of inoculum concentration on development of, S2.45

effects of environmental factors on infection of blueberry, S2.127

LAMP assay for detection on strawberry, S2.166

Colletotrichum cereale

assessment of severity on annual bluegrass, S2.65

identification and mapping of a wheat resistance gene to an unadapted isolate of, 575

Colletotrichum coccodes, S2.161

Colletotrichum dematium, $\mathrm{S} 1.3$

Colletotrichum gloeosporioides

enhancement of resistance in strawberry by overexpressing the Arabidopsis NPRl gene, S2.134 genetic structure in papaya isolates, 182 species complex causing ramulosis of cotton, S2.113

Colletotrichum hanaui, 575

Colletotrichum lindemuthianum

detection of seed to seedling transmission in pinto beans, S3.4

factors affecting seed infection in dry bean, S2.111

transmissibility by seed, S2.133

Colletotrichum spp.

anthracnose in papaya fruits, S3.11

real-time PCR detection and differentiation of species causing soybean anthracnose, S2.164

Collimonas sp. ZLZ261, S2.84

Collins, J. F., S2.36

Collins, P., S2.20

Collins, S. L., S2.115

Colquhoun, J., S2.190

Common bean (Phaseolus vulgaris) association of endornaviruses with, S2.73

Bacillus subtilis seed treatment, S2.91

Bean common mosaic virus-induced necrosis in an $I$ gene bearing line, S3.13

detection of seed to seedling transmission of Colletotrichum lindemuthianum, S3.4

endornaviruses, S1.6

field evaluation for tolerance to soilborne pathogens, S2.1

genetic and aggressiveness variation of Sclerotinia sclerotinia in Brazil, S3.9 identification of resistance gene homologues in, 156

pathogen factors affecting selection for white mold resistance, $\mathrm{S} 3.17$

rhizobacteria attenuates Curtobacterium flaccumfaciens pv. flaccumfaciens, S2.91

simple sequence repeat DNA markers linked

with broad-spectrum rust resistance, S2.132

Communication modules, in Neurospora crassa, S2.186

Comparative genomics, critical look at, S2.101

Comparative transcriptome analysis, S2.44

Compost

effect of composted manure on potato early dying, S2.98

reuse of spent mushroom compost for Agaricus bisporus production, S2.158

Compost tea, control of gray mold of blueberry, S2.20

Compost water extracts (CWEs), 255, S3.16

Comstock, J., S2.53

Comstock, J. C., S2.29

Condon, B. J., 641

Conrad, A. O., S2.29

Conrath, U., S2.77

Constantelos, C., S2.109, S2.112

Constantino, N., S2.29

Contreras, K., S2.29

Convolvulus arvensis, $\mathrm{S} 4.1$

Cook, D., S2.12

Cook, D. R., 156

Cooke, D. E., S2.33, S2.39

Cooley, D. R., S2.29, S2.88

Coons, K., S3.12

Cooper, K. D., S2.189

Copes, W. E., S2.30, S2.164

copLAB gene cluster, 409

Coplin, D., S2.171

Copper, sensitivity of Erwinia amylovora to, S2.70

Copper hydroxide, efficacy in inhibiting growth of Phytophthora infestans, S3.6

Copper resistance genes, acquisition from different sources in citrus-associated Xanthomonas, 409

Cordova-Kreylos, A. L., S2.146

Corky bark disease of langsat, S3.14

Corky root of lettuce, S2.46 
Corn (Zea mays)

aflatoxin

accumulation in IITA-ARS lines, S1.2

management with Afla-Guard, S2.158

transgenic approaches to management, S2.127

Aspergillus flavus infection

histology and transcriptional changes in infected seed, S2.133

lipoxygenase LOX2 regulates

pathogenicity of, S2.62

roles of WRKY transcription factors in

defense against, S1.4, S2.45

Clavibacter michiganensis subsp.

nebraskensis infection

within field spatial and temporal analysis, S2.35

hybrid structural responses to, S2.93

corn stunt disease resistance, 129

correlative imaging of fungal pathogenesis in,

S4.3

defense response and growth regulation in

response to Phialocephala fortinii, S2.149

dent corn resistance to Goss's wilt and

Stewart's wilt, S2.17

disease risk perceptions from the 2009

Midwestern crop management survey, S2.131

diversity of thermophilic fungi in, S2.126

effect of residue management practices on

Goss's wilt, S2.94

expression profiling and evolution of

pathogenesis related genes in response to

Ustilago maydis, S2.25

foliar fungicides and integrated pest

management, $\mathrm{S} 2.88$

fumonisin production by black Aspergillus species, S2.175

fungicide sensitivity of Pythium species in

Iowa, S3.6

histology and transcriptional changes in seed

infected by $A$. flavus and $F$. verticillioides, $\mathrm{S} 2.133$

identification of fungi associated with in northern Tamaulipas, S2.91

impact of tassel fungicides on the Aspergillus

and Fusarium spp. mycoflora of harvested

corn, S1.1

oxidized lipids control Aspergillus spp.

disease development, S2.19

pathogenicity of Pythium spp. at different

temperatures, S2.92

real-time PCR assay for interactions of seedlings with Sphacelotheca reiliana, S2.7

role of deoxynivalenol in seedling infections

by Fusarium graminearum, S2.21

role of siRNAs in viral infections, S2.187

soil bacteria for broad-spectrum

mycotoxigenic fungi control, S2.166

susceptibility to corn stalk rot, S2.117

Corn seedling blight, efficacy of metalaxyl and

ethaboxam on reducing, S3.5

Corn smut

aflatoxin and fumonisin in, S2.176

evolution and response of pathogen related

genes in corn, $\mathrm{S} 2.25$

See also Ustilago maydis

Corn stalk rot, S2.117

Corn stunt disease, 129

Cornus florida, powdery mildew resistance, S2.98

Cornus spp., foliar fungal endophytes associated with, S2.96

Corrales Osorio, A., S2.30

Corral, R., S2.30, S2.92, S2.148

Correa, V., S2.171

Correa-Victoria, F. J., S2.24

Correlative imaging, of fungal pathogenesis in

maize, $\mathrm{S} 4.3$

Correll, J., S2.124

Correll, J. C., 400, S2.24, S2.42
Corylus avellana, S3.15

Corynesporium cassiicola, S2.54

Costa de Novaes, M. I., S2.111

Costanzo, S., S2.30

Costa, S. S., S2.113, S2.122

Cota-Sieckmeyer, R. G., 1045

Cotton (Gossypium hirsutum)

Bacillus subtilis induced tolerance to damping-off, S2.94

effect of soil nitrate levels and Verticillium

dahliae populations on production, $\mathrm{S} 1.1$

effect of Verticillium wilt on fiber quality,

S2.161

evaluation of flutriafol for diseases, S1.11

influence on of crop rotation on diseases,

nematode activity, and yield, S2.23

investigating the genetic structure of cotton

root rot, $\mathrm{S} 2.27$

ramulosis, $\mathrm{S} 2.113$

target spot in Alabama, S2.54

use of soil management zones for Telone application, S1.5

Cotton leaf curl Gezira virus (CLCuGV), S3.13

Cotton root rot, $\mathrm{S} 2.27$

Cottrell, T. E., S2.17

Cottrill, D. J., S2.30

Cottyn, B., S2.152

Cotty, P. J., S2.5, S2.47, S2.66, S2.70, S2.94,

S2.105, S2.108, S2.175, S3.13

Coutinho, T. A., 1268

Cover crops

effect on root arbusuclar mycorrhizal colonization in watermelon, S4.2

general suppression of Fusarium wilt of watermelon, S2.60

Covert, S., S2.117

Covert, S. F., 400

Cowan, J. S., S3.15

Cowell, S. J., S2.31, S2.57

Cowger, C., 460, S2.95

Cox, C. E., 316, 352

Cox, F., S2.181

Cox, K., S2.31, S2.153

Coy-Barrera, E., S2.14, S2.68, S2.122, S2.151

Cranberry (Vaccinium macrocarpon)

fluorescent Pseudomonas species associated with, S2.136

fruit rot resistance and inheritance, $\mathrm{S} 2.114$ funky flower, S2.114

Crane, J. M., 146

Cranston, K., S2.48

Craterellus excelsus, $\mathrm{S} 2.58$

Craterellus guyanensis, $\mathrm{S} 2.58$

Craven, K. D., S2.55, S2.92, S2.165

Creamer, R., S2.12, S2.31

Creeping bentgrass, impact of antimicrobials on etiolation, S2.122

Cregan, P. B., S2.132

Crespo, A., S2.149

Crespo Ramirez, R., S2.55

Cripps, M., S2.15

CRISPR systems, S2.67

Cromwell, W. A., S1.2

Cronartium ribicola, $\mathrm{S} 2.143$

Cronin, H., S2.69

Crop rotation, influence on diseases, nematode

activity, and yield of peanut and cotton, S2.23

Crosslin, J. M., 1235, S2.162, S3.12

Crotalaria spp., 436

Crouch, J. A., S2.14, S2.58, S2.90, S2.179, S4.1

Crous, P. W., 400, S2.16, S2.33, S2.153, S2.162,

S2.172

Crown gall of grapevines

biological control, S2.71

magnetic capture hybridization real-time PCR assay for detecting, 633

Crown rot of wheat

effect of climate on the distribution of species causing, 1130 evaluation of Fusarium graminearum root

isolates to cause, $\mathrm{S} 2.48$

Crown rust, yield losses in oats, S2.19

Crown wilt in hickory, 565

CRT1, S2.19, S2.70

Crutcher, F. K., S2.31, S2.99

Cruz, D., S2.31

Cruz, I., S2.91

Cruz Jimenez, D. R., S2.39

Cruz, L. F., S2.32

Cryphonectria parasitica, 1280

Cryptococcus flavescens, S2.123

Cryptococcus flavescens $\mathrm{OH} 182.93 \mathrm{C}, \mathrm{S} 2.127$

CSM-1 gene, S2.152

CsrA, S2.6

Cubeta, M. A., 862, S2.21, S2.54, S2.144

Cucumber

management of Meloidogyne incognita with fluensulfone, S1.8

soil suppressiveness to Fusarium disease, 23

Cucumber downy mildew, influence of

environmental factors on disease severity, S2.52

Cucumber mosaic virus (CMV)

development assays for the identification of, S2.9

internode stunting in bell pepper, S2.100

Cucumis melo. See Melon

Cucumis metulifer (African horned cucumber),

S2.144

Cucumis spp., regulatory effect of soli matric water potentials on a tripartite host-specific rhizosphere interaction, S2.138

Cucurbit aphid-borne yellows virus (CABYV), 1188

Cucurbit bacterial fruit blotch, S2.37

Cucurbit bacterial wilt

genetic and virulence variability in strains, 900

identification and temporal distribution of potential insect vectors, S2.147

impact of plant age on development in muskmelon, S2.83

insect transmission, S2.171

See also Erwinia tracheiphila

Cucurbit chlorotic yellows virus (CCYV),

induction of antiviral responses against in

melon, 960

Cucurbit downy mildew

pathogenicity in Costa Rica, S2.16

spatial frailty modeling in survival analysis of epidemics, 216

Cucurbit powdery mildew, efficacy of fungicides

with resistance risk for, $\mathrm{S} 2.93$

Cucurbits

evolutionary history and genetic diversity of Didymella bryoniae, S2.178

genetic and virulence variability among

Erwinia tracheiphila strains, 900

latent class analysis estimation of diagnostic

tests for Squash vein yellowing virus, 1243

pathogenicity of downy mildew in Costa Rica, S2.16

Potyviridae in Puerto Rico, S3.16

Cucurbit yellow vine disease (CYVD), S2.15

Cui, M., S2.11

Culbreath, A. K., S1.8, S1.9, S2.115

Cullen, D., S2.180

Cummings, T. F., S2.149, S3.17

Cunnac, S., S2.13, S2.170

Cuomo, C. A., 400

Curlango-Rivera, G., 255, S3.16

Curly top. See Sugar beet curly top

Curry, K. J., S2.97

Curtobacterium flaccumfaciens pv.

flaccumfaciens, S2.91

Curtoviruses, S2.31, S2.120

Cushion gall, S2.122

Cut flower crops, identification of viruses in small-farms, S3.12 
Cyanodiscus, S2.112

Cyclic lipopeptides, of Bacillus mojavensis

RRC101, S2.16

Cylindrocladium buxicola, susceptibility of commercial boxwood cultivars to, S2.47

Cynodon dactylon. See Bermudagrass

Cynodon dactylon $\times$ C. transvaalensis. See

Ultradwarf bermudagrass

CYP51A1 gene, $\mathrm{S} 2.153$

Cyperus rotundus (purple nutsedge), 792

Cyst nematodes

in golf course greens, S2.103

See also Soybean cyst nematodes

Daayf, F., S2.98

da Cruz Machado, J., S2.153

Daglish, G., S2.59, S3.4

da Graça, J. V., S2.75, S2.86

Dahlia, identification of viruses in small-farm cut

flower crops, S3.12

Dai, R., S2.32

Dalby, M., S2.186

Dale, A. L., S2.32

Daley, J. D., S2.32

Dalling, J., S2.30, S2.48

Dally, E. L., S4.1

Dalsing, B. L., S2.32

Damacena, M. B., S2.107

Damann, K., S2.32

Damarwinasis, R., S2.29

Damicone, J., S1.3

Damm, U., S2.33

DAMP induced innate immune response, $\mathrm{S} 2.118$

Damping-off

in cotton, Bacillus subtilis induced tolerance, S2.94

evaluation of fungicides and biorational products for greenhouse management, S2.13 in soybean, oomycetes from isolates in South Dakota, S2.25

Danelli, A. D., S3.5

D’Angelo, D., S2.33

Dang, H., 741

Daniells, E., S2.148

Daniels, J., S2.33, S2.176

Danies, G., S2.33

Dann, E. K., S2.71

Danojevic, D., S2.21

Daròs, J.-A., 870

Darrasse, A., S2.171

Dart, N. L., S2.33

da Silva Leite, D., S2.15, S2.67

Das, M., S2.16, S2.34

Date palm (Phoenix dactylifera)

evaluation of germplasm to

resistance/susceptibility against Bayoud disease, S2.125

molecular and cellular responses of roots to salinity stress, S3.8

morphological and molecular characterization of Fusarium species, S2.39

Daub, M., S2.189

Daub, M. E., S2.15

Daughtrey, M. L., S2.136

Dave, A., 1069, S2.4, S2.140

Davelos Baines, A. L., 1280

David, A. S., S2.34

David, G., S2.9

David, M., S2.24, S2.182

David, P., S2.170

Davidson, J., S2.74

Davis, A., S2.48

Davis, D. D., S2.71

Davis, E. L., 175, S2.129

Davis, J., S1.3

Davis, N., S2.181

Davison, D., S2.141

Davis, R. E., S2.26, S4.1

Davis, R. M., S2.173
Davis, W. J., S2.34

Dawson, N., S2.28

Dawson, W. O., S2.31, S2.55, S2.57

Day, A., S2.74

Dean, R., S2.188

De Backer, M., 1169

DeBauw, A., S3.12

De Bello, P., S4.2

Deblais, L., S2.148

Debolt, S., S2.163

DeBuse, C., S2.163

Decline of ironwood, S2.10, S2.128

Dee, M., S2.109

Deep sequencing of small RNAs, 1077

Dehesh, K., S2.122

Dehne, H., S2.99

Deiulio, G., S2.34

Déjean, G., S2.170

De Jong, D. M., S2.101

De Kesel, A., S2.54

Dela Cueva, F. M., S2.179

De La Fuente, L., S2.32, S2.102, S2.107

de la Garza, C., S2.75

de la Paz Gimenez Pecci, M., 129

Delbridge, R. W., S2.8

Delfosse, P., S2.38

Delgado-Alvarez, D., S2.34

Delgado, N. P., 555

Delia radicum, $\mathrm{S} 2.53$

del Rio, H., S2.152

del Rio, L. E., S2.27

del Río-Mendoza, L., 750

Demangeat, G., S2.51, S2.188

Demers, J. E., S2.68

Demethylation inhibitor (DMI)

field selection of Sclerotinia homoeocarpa isolates for insensitivity, S2.5

resistance mechanisms in Erysiphe necator, S4.3

sensitivity of Cercospora kikuchii to, S1.9

Deng, P., S2.35

Deng, X., S2.67

Denitrification pathway, in nitric oxide

detoxification of Fusarium vertcillioides, S2.11

Dent corn, resistance to Goss's wilt and Stewart's wilt, S2.17

Denton, G., 43

Denton-Giles, M., 725

Deom, C. M., S2.20

Deoxynivalenol (DON)

concentrations during development of wheat spikes, 460

effect of QoIs on in soft red winter wheat, $\mathrm{S} 2.33$

effect of rain and simulated rain on levels in winter wheat, S2.97

regulation of systemic translocation in wheat, 460

role in seedling infections of soybean, wheat, and maize, S2.21

de Resende, V. L., S2.91

DeRobertis, C., S2.32

Deschutes National Forest, S2.48

de Silva, A. S., S2.6

DeSilva, U., 373

De Souza, J. I., S2.34, S2.68, S2.153

Devan, M. M., S2.62

Dever, J. K., S2.161

de Vicente, A., 1115

De Vos, P., S2.46

Dewdney, M. M., S2.152, S2.156

De Wever, G., S2.72

De Wolf, E. D., 906, S3.4

Deyiteux, V., 1012

Dharmasiri, C., S2.70

Dhillon, B., S2.35

Dhiman, C., S2.103

Dhulipala, M. R., S2.27

2,4-Diacetylphlolorglucinol (2,4-DAPG), S2.100
Diagnostic outreach trainings, S2.153

Dianese, J. C., S2.3, S2.112, S2.127, S2.137

Diao, Y., 920

Diaphorina citri, testing project in Florida, S2.55

Diaporthe spp.

delimitation of tropical endophyte species, S2.134

molecular phylogenetic studies, S2.150

pathogenicity on soybeans from Minnesota, S2.89

Diaz-Arias, M. M., 822, S2.35

Diaz, C. I., S2.35

Diaz Lara, A., S2.35

Diaz Valderrama, J. R., S2.35

Di Bello, P. L., S1.3

Dickens, A. A., S2.177

Dickeya, S2.82

Dickie, I., S2.182

Dickman, M., S2.79

Dicymbe alstonii, S2.150

Dicymbe corymbosa, S2.135

Didymella bryoniae evolutionary history and genetic diversity, S2.178

sensitivity of conidial germination and mycelial growth to azoxystrobin, S1.4 stability of azoxystrobin resistance in, S2.43

Didymium iridis, S2.90

Dietzgen, R. G., S2.148

Difenoconazole resistance, in Venturia inaequalis isolates, $\mathrm{S} 2.153$

Digalactosyldiacylglycerol (DGDG), 74

'Digu' rice variety, 594

Dijkwel, P. P., 725

Dima, B., S2.142

Ding, F., 15, S2.165

Ding, X. S., S2.7

Dinkeloo, K., S4.2

Dinkins, R. D., S2.101

Diphymyces, S2.54

Di Pietro, A., 400

Diplodia pinea, assessing reactive oxygen species scavenging by, S2.132

Diplotaxis tenuifolia (wild rocket), 23

Di, R., S2.167

Disease control and pest management effect of Fusarium head blight-Stagnospora leaf blotch management on soft red winter wheat, S2.173

effect of host nitrogen nutrition on Botrytis cinerea secondary inoculum, 261

effect of transitional organic production practices on tomato soilborne pests, 792

factors limiting trichothecene contamination of wheat grains after Fusarium culmorum infection, 682

field treatment of grapevine bois noir with resistance inducers, 785

fungicide strategies in resistance management for Mycosphaerella graminicola on winter wheat, 690

influence of environmental factors and management practices on potato zebra chip occurrence, 1235

integrated approach to tomato sour rot management, S2.173

integrated control of Allium white rot, S2.173

management of bacterial rots of onion, S2.173 membrane-based oligonucleotide array for the detection Phytophthora spp., 43

roguing with replacement in perennial crops, 117

seed treatment innovations, S2.174

Xanthomonas arboricola pv. pruni and leaf abscission on peach and nectarine, S2.173

Disease resistance evaluation, spurious symptoms caused by inoculum carriers, S3.5

Disease resistance inhibitor genes, 472

Disease risk curves, 1108 
Disease severity, calculating fungicide dose decisions and, 666

Disinfestants, efficacy in killing urediniospores of

wheat stem rust and soybean rust, S3.2

Distance courses and programs, S2.189

Diuraphis noxia (Russian wheat aphid), S2.87

Divakar, P. K., S2.149

Dixon, P. M., 900

Dixon, W., 15

Djama, Z. R., 43

Djikeng, A., S2.76

DMI resistance, mechanisms in Erysiphe necator,

S4.3

DNA amplifiability, S2.6

DNA barcoding

for detecting quarantine fungi, 1103

of rust fungi from the Brazilian Cerrado, S2.137

DNA extraction, evaluation of a seed wash

method, S2.140

DNA hybridization, membrane-based

oligonucleotide array for the detection

Phytophthora spp., 43

DNA methylation, in Fusarium species, S2.34

DNA microarrays, modification of oligo design

for detection of fungal onion bulb rot pathogens, $\mathrm{S} 2.8$

DNases, fungal mitochondrial DNases and the

activation of nonhost resistance, 81

DNA viruses, association with grapevine red

blotch disease, 1069, S2.4

Dobhal, S., S2.8

Doktycz, M., S2.18

Dolezal, W., 129, S3.3

Dollar spot

identifying the pathogen of, S2.14

See also Sclerotinia homoeocarpa

Doll, D. A., S3.12

Döll, K., 682

Domfeh, O., S3.3

Domier, L. L., 941, S2.3, S2.24, S2.164

Donahoo, R. S., 237, S2.36

Donaldson, J., S1.5

Donaldson, M., S2.26

Dong, J., S2.26

DON-3-glucoside (D3G), 682

Dong, Y., S2.97

Donofrio, N., S2.36, S2.143, S4.3

Doohan, F. M., 1260

Dornelas, G., S2.151

Dorner, J. W., S1.8

Doster, M. A., S2.175

Dothideomycetes

genomic analysis, S2.106

merging the genera of, S2.172

Dothideomycetes Consortium, S2.106

Doud, M. S., 15

Douglas-fir (Pseudotsuga menziesii), gene

expression profiling of a compatible interaction

with Phellinus sulphurascens, 583

Douglas, S. M., S2.36

Douhan, G. W., 91, S2.91, S2.107

Doungsa-ard, C., S2.94

Doussoulin, H. A., S2.100

Dowie, N. J., S2.36

Downey, S., S2.36

Downy mildew

of basil

control with acibenzolar- $S$-methyl, S2.95

effect of plant age on, S2.111

incubation and latent periods, S3.6

management by seed treatment with oxathiapiprolin, S2.111

of cucumber, influence of environmental

factors on disease severity, S2.52

cucurbit downy mildew

pathogenicity in Costa Rica, S2.16

spatial frailty modeling in survival

analysis of epidemics, 216 graminicolous

biology of, S2.178

environmental metagenomics, S2.178

identification and diagnosis of

Peronosclerospora and Sclerophthora, S2.179

in North America, S2.178

taxonomy and phylogeny, S2.178

of Impatiens, management, S2.109

of quinoa, detection in quinoa seeds, S2.191

of sorghum, $\mathrm{S} 1.7$

of spinach, examination of molecular diversity

with SSRs, S2.42

Downy mildew resistance, abiotic stresses affect

Trichoderma harzianum T39-induced resistance in grapevine, 1227

Doyle, C., S2.26

Draper, M. A., S2.190

Drechsler, D. T., S2.36

Dried fruits, fungal contaminants, S2.147

Driver, J., S2.134

Drought resistance, fungal endophytes and, S2.183

DSF-mediated signaling system, in Burkholderia

glumae, $\mathrm{S} 1.2$

D'Souza, D. H., S2.109

Duan, J., 1243

Duan, Y., 15

Duan, Y. P., S2.69, S2.72, S2.118

Dubien, J., S2.153

Dubois, T., S2.70

Du, C., S2.171

Duceppe, M. O., S2.147

Dufault, N. S., S1.1, S2.81

Dugan, F., S2.8

Dugan, F. M., S2.37, S2.160

Dugyala, S., S2.37, S3.3, S3.9

Du, L., S2.184

Duncan, R., S2.114

Duncan, S. M., S2.95

Dune ecosystems

arbuscular mycorrhizal fungi communities, S2.69

fungal endophytes and ecosystem engineering in, $\mathrm{S} 2.183$

Dungan, B., S2.138, S3.14

Dung, J. K. S., 55, 445, S2.37

Dunham, J. P., S2.134

Dunlap, C. A., S2.127

Dunn, A., S2.141

Dunn, A. R., S2.37

Duplessis, S., S2.42

du Toit, L., S2.8, S2.131

Dutta, B., S1.3, S2.37

Dvornik, J., S2.182

Early blight management, in tomato, S2.101, S2.118

Eastern filbert blight, S3.15

Eastwell, K. C., 1287

Eberhart, J., S2.77

Echauri-Espinosa, R., S2.118

Echidnodella, S2.137

Echinacea purpurea, S2.105

Eck, E., S2.38

Eckhardt, L. G., S2.26

Ecology and epidemiology

aggressiveness and yield impact of Fusarium species in soybean, 822

Ceratocystis smalleyi infections reduce sap

flow in bitternut hickory, 565

effect of climate on the distribution of Fusarium spp. causing crown rot in wheat, 1130

effects of frequency of "extreme" temperature highs on soybean rust development, 708

factors affecting foliar strawberry powdery mildew severity, 811, 1087

Fusarium graminearum infection and deoxynivalenol concentrations in wheat spikes, 460 genetic structure of Verticillium dahliae populations from mint and potato, 445 incidence and impact of Verticillium dahliae in soil associated with certified potato seed, 55

latent class analysis estimation of diagnostic tests for Squash vein yellowing virus, 1243 percolation-based risk index for pathogen invasion, 1012

polymorphic microsatellite markers for

Phytophthora spp., 1020

population dynamics of Phytophthora ramorum, 1141

production and release of asexual sporangia in Plasmopara viticola, 64

real-time PCR assay for Fusarium oxysporum, 802

temperature regulation of chasmothecia

initiation in powdery mildew of strawberry, 717

temperature/wetness modeling of Guignardia pseudothecium maturation and ascospore release, 281

Verticillium wilt on spinach, seed localization and efficacy of seed treatments, 268 weather-driven logistic regression models predicting Fusarium head blight epidemics, 906 weeds as potential inoculum sources for a tomato-infecting begomovirus, 436

Ecosystem engineering, fungal endophytes in

dune ecosystems, S2.183

Ectomycorrhizal fungi

associated with Alnus and Salix, S2.182

associated with Dicymbe alstonii and Coccoloba lianas, S2.150

associated with Pinus contorta and $P$. ponderosa, $\mathrm{S} 2.48$

communities on pine and oak seedlings, S2.160

community structure along a complex

hydrologic gradient, S2.41

ecophysiological responses to climate change, S2.183

effects of nitrogen availability at the regional scale, S2.181

factors affecting Alnus-associated community diversity and specificity, S2.124

investigations of Chrysolepis chrysophylla and Pinus ponderosa, $\mathrm{S} 2.85$

response to recurring prescribed fires in yellow pine forests, S2.107

spatial structure in Dicymbe corymbosa trees and stands, S2.135

variation in composition along a montane soil nutrient gradient, $\mathrm{S} 2.30$

Ectotrophic fungi, association with ultradwarf

bermudgrass, S1.10, S2.153

Edlebeck, K., S2.106

Edythea quitensis, S2.12

EF1 $\alpha$ gene, 479

Eggers, J. E., 55, S2.38, S2.131

Egusa, M., 733

Ehteshamul-Haque, S., S2.18, S2.38

Eicosapolyenoic fatty acids, S2.122

Eid, S. G., S2.38, S3.15

eIF4E-mediated resistance, $\mathrm{S} 2.8$

Ekramoddoullah, A. K. M., 583

Elaphocordyceps, S2.109

Elderberry, carlaviruses detected in, S2.72

Elena, S. F., 870, 1188, S2.179

El-Ganainy, S. M., S2.39

El Hadrami, A., S2.98

Elias, E., S3.2

Elías-Román, R. D., S2.39

Elite spring barley, quantitative resistance to

Fusarium head blight, 1252

El Jarroudi, M., S2.38

El-Komy, M. H., S2.39, S2.125

Elling, A. A., 1092 
Elliot, M., S2.82

Ellis, M., S2.39

Ellis, M. A., S2.26

Ellis, M. L., S2.31, S2.39, S2.40

Elmer, W., S2.40

Elmer, W. H., 400

Elsinoë australis

novel PCR-RFLP assay for genetic diversity

studies, S2.30

SNPs present in the ITS2 region of, S2.141

Emerging pathogens, Saharan dust storms and, S2.83

Emery, S., S2.183

Enamovirus, associated with Citrus vein enation, 1077

Endohyphal bacteria, S2.8

Endolichenic fungal communities, S2.150

Endophytes

boreal endophytic fungal communities, S2.150 cell-cell signaling and endophytic behavior in Xylella fastidiosa, S2.186

characterization of culturable bacterial endophytes of switchgrass, S2.163

effect on tall fescue under drought stress, S2.101

effects of environment and host on

communities in coastal dune grasses, S2.34

effects of rainfall on communities associated

with five grass species, S2.161

endophytic relationships and soilborne fungal pathogens, 538

exploring endophyte diversity across the

Pooideae, S2.165

genomic comparison of closely related boreal endophytes, S2.161

infections in Poa alsodes, S2.133

seed endophytes of the alpine tundra in

Colorado, S2.146

tall fescue endophyte utilization, quality assurance, and characterization, S2.142

in vitro evaluation of antagonists of Fusarium oxysporum and Botrytis cinerea, S2.122

See also Foliar fungal endophytes; Fungal endophytes

Endoraecium, S2.94

Endornaviruses

association with common bean, S1.6, S2.73

infection of lima bean, S2.2

Endospore-forming bacteria, biocontrol of

Rhizoctonia solani, S2.17

Endosymbiotic bacteria, co-evolution with

Mortierella elongata, S2.18

End-point multiplex PCR, development for identification of plant viruses, S2.9

End-point RT-PCR, evaluation for the detection

of High plains virus, S2.9

English, J., S2.120

English walnut (Juglans regia), S2.163

Enomoto, T., 575

Enteric disease, 316

Enteric pathogens

biocontrol on leafy greens, S2.90

food safety and, S2.185

transmission to leafy greens by flies, S2.185

Enterobacteriaceae, 1268, S2.87

Enterobryus, association with Anadenobolus monilicornis, S2.29

Entolomataceae, $\mathrm{S} 2.71$

Entomophthora muscae, S2.53

Epichlö festucae, molecular and genetic basis of

mutualism with perennial ryegrass, S2.13

Epidemics

field evaluation of southern corn rust epidemics, S1.1

predicting Fusarium head blight epidemics with weather-driven logistic regression models, 906

predicting stripe rust epidemics using general estimation equations, S3.4 relating the progeny production curve to the speed of an epidemic, 204

spatial frailty modeling in survival analysis of

cucurbit downy mildew epidemics, 216

of stripe rust in barley, S2.155

Epiphytic bacteria, effect on survival of

immigrant cells of Salmonella enterica, 341

Epstein, L., 400

Eranthodi, A., S2.125

Erasmus, A., S2.72

Ergot

alteration of alkaloid profile through

chromosome end knockoff, S2.44

ergot alkaloid pathway, S4.3

spatial patterns in Kentucky bluegrass and perennial ryegrass grown for seed, S2.37

Er, H. L., S2.40

Erlandson, S., S2.41

Erwinia amylovora

control with trunk injection of SAR inducers and antibiotics in apple, S2.2

CsrA positive regulation of virulence factors in, S2.6

genomics of pathogen-host interactions, S2.172

iron competition as mechanism for biocontrol by Aureobasidium pullulans, S2.150

presence in asymptomatic apple bud wood, S2.31

sensitivity to streptomycin, kasugamycin, and copper, S2.70

Erwinia herbicola, 341

Erwinia tracheiphila

genetic and virulence variability among strains, 900

impact of plant age on development in muskmelon, S2.83

insect transmission, S2.171

insect vectors, S2.147

Erysiphe necator

mechanisms of DMI resistance in, $\mathrm{S} 4.3$

ontogenesis of conidiation, $\mathrm{S} 2.93$

real-time detection of airborne inoculum, S2.144

Esca disease

explaining grapevine defense response to, 1028

See also Phaemoniella chlamydospora

Escamilla Sanchez, D. M., S1.6, S2.76

Escherichia coli $\mathrm{O} 157: \mathrm{H} 7$

colonization and internalization, 333

plant immunity against, 326, S2.185

transfer to spinach by house flies, 373

transmission by flies, S2.185

Esenbeckia alata, S2.68

Eskalen, A., S2.71

Esker, P. D., S1.1, S2.88, S2.123, S2.131

Esmenjaud, D., 833

Espindola, A., S2.33, S2.176

Espitia-Vazquez, I. M., S2.41

Essential oils, impact on Beauveria bassiana S2.84

Estep, L., S2.41

Estevez de Jensen, C., S2.191, S3.13, S3.16,

S3.17

Ethaboxam, efficacy in reducing corn seedling blight, S3.5

Eujayl, I. A., S2.139

Euphorbia heterophylla, 436

Euphorbia yellow mosaic virus, 436

Eurasian poplar leaf rust, S2.42

Eurotiomycetes, S2.26

Euwallacea, S2.71, S2.114

Evans, B., S2.67, S2.70

Evans, T. A., S2.36

Everhart, S. E., S2.32, S2.41

Eversole, K., 306

Everts, K., S2.60, S2.141, S4.2

Everts, K. L., S2.36, S2.89
Ewer, J., S2.108

Expressed sequence tag (EST) markers, fine mapping of leaf rust resistance gene $\mathrm{LrZH} 84$, 169

Extension and education

effective metrics for documenting impact, S2.190

mobile technologies to increase effectiveness, S3.6

Eyre, C. A., 1141

Faculty, creating financial and academic incentives in on online programs, S2.189 Faedda, R., 610

Faeth, S. H., S2.105, S2.133, S2.165, S2.185

Fagus grandifolia, Neonectria infection, S2.23

Fajardo-Somera, R., S2.186

Fakhoury, A. M., 1045, S2.101, S2.158

Falcone, J., S2.51

False smut, S1.10

False spider mite (Brevipalpus phoenicis), 488

Fan, Y., S2.184

Farber, D., S2.41

Faria, M. d. R., S2.143

Farman, M. L., S2.44

Farrar, J. J., S3.13

Farrell, A., S3.11

Farrer, E., S2.60

Farria-Medina, O., S3.17

Faske, T. R., S2.42

Faure, C., 293

Favaro, M. A., 555

Fayad, A., S2.42

Fayette, J., S1.3

Feau, N., S2.32, S2.35, S2.42

Febres, V., S2.132

Fei, Z., S2.70

Felix-Gastelum, R., S2.94

Feliziani, E., 785

Feng, C., S2.42, S2.124

Feng, J., 1052, S2.42

Feng, J. X., S2.170

Feng, X., S2.42, S3.13

Fenstermacher, K. A., S2.71

Fereidouni, M., S2.43

Fereres, A., 1188, S2.179

Fernandes, J. M. C., S3.3

Fernandes, R. B., S2.100, S2.137

Fernandez, J., S2.43

Fernández-Ortuño, D., S2.43, S2.51

Fernandez-Pavia, S. P., S2.15, S2.136

Ferrandino, F. J., 204

Ferreira, M. A., S2.43

Ferro, H. M., S2.94

Ferrucho, R. L., 862

Ferry, A. E., S2.173

Fertilization, response of soil microbial

communities to, $\mathrm{S} 3.4$

Feussner, I., S2.29

Feussner, K., S2.29

Ficcadenti, N., 802

Fichtner, E. J., S2.163

Ficke, A., S2.43

Fiedler, K., S2.120, S2.173

Fieland, V., S2.139

Fierro, J., S2.151

Filamentous fungi, septum formation and cytokinesis, S2.187

Filion, M., 995

Filippone, M. P., 555

Filley, T. R., S2.95

Filson, P. B., S2.109

Filth flies, as vectors, 373

Finger, M. J., S1.4, S2.43

Fiorani, F., S2.128

Fire

effect on foliar endophytes of Quercus hypoleucoides and Juniperus deppeana, S2.62 responses of mycorrhizal fungi to, S2.183 
Fire blight. See Erwinia amylovora

Fischer, I. H., S2.104

Fischer, M., S2.49

Fiser, S., S2.24

Fisher, K. E., S2.44

Fisher, T., S2.44

Fjellstrom, R. G., S2.24

Flaherty, J., S2.120

Flavescene dorée disease, 776

Flavohemoglobins, S2.11

Fleites, L. A., 15, S2.44, S2.66

Fletcher, J., 129, 306, 373, S2.7, S2.9, S2.33,

S2.99, S2.176

Flg22, S2.132

Flies, transmission of human enteric bacteria, S2.185

Flora, E., S3.12

Florea, S., S2.44

Flores, D., S2.44

Flores, F., S2.44

Flores, F. J., S2.52

Flores-Gonzalez, E., S2.134

Floudas, D., S2.101, S2.180, S2.181

Flowering dogwoods, powdery mildew resistance, S2.98

Fludioxonil resistance, in isolates of Botrytis cinerea from small fruits, S2.51

Fluensulfone, control of Meloidogyne incognita in cucumber, S1.8

Fluorescence in situ hybridization (FISH), visualization of 'Candidatus Liberibacter asiaticus' cells in citrus seed coat vascular bundles, 545

Fluorescent Pseudomonas association with mycorrhizosphere of mungbean, $\mathrm{S} 2.18$

biocontrol of isolates from Salvadora species, S2.38 species associated with cranberry, S2.136

Fluorimetric probes, in the quantification of

reactive oxygen species in plants, S2.24

Flutriafol, evaluation for cotton and peanut

diseases, S1.11

Flyspeck fungi, S2.12

Fofanov, V. Y., S2.114

Foley, M., S3.13

Foliar fungal endophytes

associated with Cornus spp., S2.96

effects of wildfire on in Quercus

hypoleucoides and Juniperus deppeana, S2.62 phenotypic effects of endohyphal bacteria on, S2.8

Foliar fungicides, in IPM with hybrid corn, S2.88

Foliar pathogens

modeling study on the use biocontrol agents in, 108

synergy from the combined of two biocontrol agents, 768

Folimonova, S. Y., 545, S2.156

Folta, K. M., S2.134

Foltz, M. J., S2.45

Fontem, D. A., S2.103

Food safety

contributions of plant pathologists to, S2.184

emerging issues of mycotoxins in, S2.175

enteric viruses and, S2.185

focus issue on, 304

Forbes, G., S2.145, S3.8

Forcelini, B. B., S2.45

Forcelini, C. A., S3.5

Foreman, A., S2.187

Forensic epidemiology, S2.176

Forest pathogens, development of detection tools,

S2.76

Forest seedlings, host generalism in fungal

pathogens and endophytes, S2.14

Forest soils, metagenomic approaches to

microbial communities, S2.123

Formella, A., S3.12
Forster, H., S2.3, S2.138

Founder effects, in Wheat yellow mosaic virus, 949

Fountain, F. C., S1.4

Fountain, J. C., S2.45

Fourie, P., 281

Fourie, P. H., S2.72

Fragaria $\times$ ananassa. See Strawberry

Fraility modeling, in survival analysis of cucurbit

downy mildew epidemics, 216

France, R. A., S2.45

Francis, F., S1.2

Francis, I., S2.45

Francis, I. M., S2.46, S2.77

Francis, M., S2.90

Franco, C., S2.130

Francois, M., S3.5

Franco-Lara, L., S2.46

Franco, O., S2.62

Frandsen, R. J. N., 400

Frank, J. L., S2.58

Frankliniella occidentalis, S3.2

Franks, R. G., S2.133

Frantz, G., S2.158, S3.13

Fraser, E., S2.92

Fraxinus uhdei, $\mathrm{S} 2.46$

Frazier, T., S2.46

Frederick, L., S2.74

Freeman, J. H., S2.120

Freeman, S., 400, S2.71

French-Monar, R. D., S2.130, S3.13, S3.16

French, R., S2.143

Frettinger, P., 1035

Frey, P., 190, S2.42

Frisesen, T. L., S3.7

Fritz, C., S2.135

Frogeye leaf spot, 1045

See also Cercospora sojina

Frommer, W., S2.167

Frost, K., S3.5

Frosty pod rot of cacao, $\mathrm{S} 2.35$

Fruit rot

anthracnose fruit rot of strawberry, S2.45

management in a high brix Niagara grape production, $\mathrm{S} 2.58$

Phytophthora fruit rot of watermelon, management, S1.6

postharvest fruit rot in apple, S2.160

of rambutan, identification in Puerto Rico, $\mathrm{S} 2.130$

resistance and inheritance in cranberry, $\mathrm{S} 2.114$

Fry, J., S3.9

Fry, W., S2.134

Fry, W. E., S2.33

Fuchs, M., 1180, S2.46, S2.51, S2.145

Fuentes, S., S2.1

Fukami, T., S2.181

Fulbright, D. W., 1280

Fulladolsa Palma, A. C., S2.46

Fulmer, A. M., S1.4

Fumiglobus pierisicolus, S2.19

Fumonisin

in corn smut galls, S2.176

production by Aspergillus niger in grapes, S2.175

production by black Aspergillus in maize, S2.175

Funahashi, F., S2.46

Funderburk, J., S2.158

Fungal diversity

extrapolating local to global biodiversity, S2.182

in North American pine forests, S2.182

of the southern states of the U.S., S2.151

Fungal ecology, S2.181

Fungal endophytes

climatic drivers and their impacts on plant drought resistance, S2.183 dual mutualist-antagonist dynamics in grasses, S2.185

ecosystem engineering in dune ecosystems,

S2.183

production of acid protease by root endo-

phytes, S2.92

seed endophytes of the alpine tundra in

Colorado, S2.146

See also Endophytes; Foliar fungal endophytes

Fungal nomenclature, S2.172

Fungi

AtBAG6 regulation of autophagy in fungal pathogen resistance, $\mathbf{S} 2.79$

cell biology of, S2.186

characterization of LSU and ITS rDNA for

automated classification, S2.115

colonization of roots of native and exotic hosts in urban environments, $\mathbf{S} 2.86$

correlative imaging of fungal pathogenesis in maize, $\mathrm{S} 4.3$

digitization projects, S2.97

hidden host plant associations of soilborne pathogens, 538

host specificity of phyllosphere communities in tropical trees, S2.13

mitochondrial DNases and the activation of nonhost resistance, 81

modeling decomposition pathways across scales, S2.181

obligately lichen-associated, S2.186

Open Tree of Life Project, S2.48

responses of plant-symbiotic fungi to climate change, S2.182

role of sRNAs in host-fungal interactions, S2.187

succession across a deglaciated forefront, S 2.20

See also individual fungi and fungal diseases

Fungicide resistance

in Alternaria spp. from California pistachio orchards, S3.11

in Cercospora kikuchii, S2.116

fungicide application timings for disease control are an effective anti-resistance strategy, 1209

in isolates of Botrytis cinerea from small fruits, S2.51

management strategies for Mycosphaerella graminicola on winter wheat, 690

review of current knowledge of SDH resistance, 880

survey of in Botrytis cinerea in Virginia vineyards, S2.12

See also specific fungicides

Fungicides

application timings for disease control are an effective anti-resistance strategy, 1209

calculating dose decisions that account for economic risk caused by variation in disease severity, 666

effects on the latent stage of pecan anthracnose, $\mathrm{S} 1.5$

importance for feeding the world, S2.49 strategies in resistance management for Mycosphaerella graminicola on winter wheat, 690

See also specific fungicides

Funky flower in cranberry, S2.114

Funnell-Harris, D. L., S3.3

Furr, S. H., S2.62

Furuya, N., 960

Fusaric acid secretion, S2.31

Fusariosis of black pepper, S2.113

Fusarium andiyazi, S2.134

Fusarium circinatum

evidence for multiple introductions and clonality in Spanish populations, 851 symptomless infection of Pinus radiata seedlings, S2.191 
Fusarium crown rot of wheat

effect of climate on the distribution of species causing, 1130

evaluation of Fusarium graminearum root isolates for their ability to cause, S2.48

Fusarium culmorum

brassinosteroid enhancement of resistance in barley, 1260

effect of climate on the distribution of, 1130 factors limiting trichothecene contamination in wheat grains after infection, 682

Fusarium decemcellulare, S2.122

Fusarium dieback, S2.114

Fusarium fujikuroi, hybrids with $F$. proliferatum, $\mathrm{S} 2.98$

Fusarium graminearum aggressiveness and yield impact in soybean, 822

comparative analysis using next generation sequencing, S2.134

effect of QoIs on in soft red winter wheat, $\mathrm{S} 2.33$

evaluation of ability to cause crown rot in wheat, S2.48

gene regulatory network reconstruction in, S2.53

genetic and epigenetic profiling, S2.55

identification of genes involved in asexual reproduction, S2.120

role of deoxynivalenol production in seedling infections by, S2.21

susceptibility of corn to, S2.117

wheat spike infection and deoxynivalenol concentrations, 460

See also Fusarium head blight

Fusarium head blight (FHB)

biological control study, 146

characterization and field detection of Cryptococcus flavescens biocontrol agents, S2.123

effect of intermittent pre- and post-anthesis moisture patterns on, S2.7

effect of management on soft red winter wheat, S2.173

effect of QoIs on in soft red winter wheat, S2.33

effect of rain and simulated rain on

deoxynivalenol levels in winter wheat, S2.97

factors limiting trichothecene contamination

in wheat grains after infection, 682

IPM with Cryptococcus flavescens $\mathrm{OH} 182.9$ 3C, S2.127

predicting epidemics with weather-driven logistic regression models, 906

quantitative resistance in elite spring barley,

1252

wheat spike infection and deoxynivalenol

concentrations, 460

See also Fusarium graminearum

Fusarium kyuyense, S2.134

Fusarium lactis, S2.136

Fusarium mexicanum

association with galls of Swietenia, S2.136

causing malformation in mango, $\mathrm{S} 2.15$, $\mathrm{S} 2.136$

Fusarium nelsonii, S2.134

Fusarium oxysporum

biocontrollers, S2.14

Fusarium stalk blight and rot in sugar beet, S2.56

infection of above-ground plant tissue by nonpathogenic conidia, S2.68

interaction with soybean cultivars in seedling

disease, $\mathrm{S} 2.31$

real-time PCR assay detection in grated melon genotypes, 802

in vitro evaluation of endophytic fungi antagonists, S2.122

Fusarium oxysporum f. sp. albedinis, S2.125
Fusarium oxysporum f. sp. lactucum, S3.17

Fusarium oxysporum f. sp. lycopersici, S2.9

Fusarium oxysporum f. sp. melonis genetic structure among vegetative compatibility groups, S2.97

real-time PCR assay for detection and quantification of, 802

Fusarium oxysporum f. sp. niveum, S2.60

Fusarium oxysporum f. sp. phaseoli, S2.153

Fusarium oxysporum f. sp. radiciscucumerinum,

23

Fusarium oxysporum f. sp. vasinfectum, S2.31

Fusarium oxysporum species complex (FOSC) genotypic and phenotypic characterization of isolates from soybean roots, $\mathrm{S} 2.39$

PCR-RFLP fingerprinting of isolates from soybean, S2.40

Fusarium proliferatum

aggressiveness and yield impact in soybean, 822

hybrids with $F$. fujikuroi, S2.98

specific discrimination using ISSRs and SSRs, S2.99

Fusarium pseudograminearum, 1130

Fusarium root rot resistance, evaluation of

greenhouse inoculation methods to screen germplasm for, S3.7

Fusarium seedling blight (FSB), brassinosteroid enhancement of resistance in barley, 1260

Fusarium solani, 255

Fusarium solani f. sp. phaseoli, 81

Fusarium solani f. sp. piperis, S2.113

Fusarium solani f. sp. pisi, S3.7

Fusarium solani species complex, S2.113

Fusarium spp. aggressiveness and yield impact in soybean, 822

brassinosteroid enhancement of resistance to Fusarium diseases in barley, 1260 characterization and quantification on wheat roots, $\mathrm{S} 2.83$

defining, 400, S2.172

DNA methylation patterns, S2.34

effect of climate on the distribution of species causing crown rot in wheat, 1130

effect of tassel fungicide applications on harvested field corn, S1.1

morphological and molecular characterization of date palm isolates, S2.39

phylogenetic diversity of fusaria cultivated by ambrosia beetles, S2.71

species composition comparison between New England and Chinese salt marshes, S2.40

Fusarium stalk blight and rot, in sugar beet, S2.56

Fusarium tucumaniae, comparison with $F$.

virguliforme, $\mathrm{S} 2.163$

Fusarium verticillioides

analysis of nitric oxide detoxification, S2.11

antifungal activity of Bacillus mojavensis

RRC101, S2.16

effect of FST1 mutations in, S2.104

FvStr2 protein, S2.167

genetic structure and effective population size from maize hybrids in the U.S., S3.4

Fusarium virguliforme aggressiveness and yield impact in soybean, 822

comparison with $F$. tucumaniae, S2.163

effect on location of soybean cyst nematode syncytia in soybean roots, S2.143 genome expression of soybean roots and leaves infected by, S2.117

temporal dynamics of soybean root colonization, S2.157

Fusarium wilt

of lettuce, evaluation and relative susceptibility of varieties, S3.17

of watermelon, general suppression with cover crops, S2.60
Fusicladium effusum

fungicide spray coverage from ground-based sprayers, S2.17

trunk application of phosphite for control of, $\mathrm{S} 2.17$

Fusicoccum aesculi, S2.104

Fu, Y., S2.98

FvStr2 protein, S2.167

Gabriel, D., 15

Gabriel, D. W., S2.44, S2.66

Gac-Rsm pathway, S2.155

Gadagkar, S. R., S2.136

Gadoury, D., S2.14, S2.22, S2.161

Gadoury, D. C., S2.93

Gadoury, D. M., 717, S2.10, S2.93

Gagkaeva, T., 400

Gagnevin, L., S2.67, S2.170

Gajdeczka, M., S2.149

Galarneau, E., S2.13

Gallagher, L., S2.47

Gallery, R. E., S2.48, S2.130

Galls, of Swietenia, S2.136

Galvão, L. M., S2.91

Gambino, G., 776

Gamble, B. E., S2.23

Gambone, K., S2.132

Gamliel, A., 23, S2.99

Ganci, M. L., S2.47

Gangadharan, A., S2.47

Gang, D. R., S2.44

Ganiger, M., S1.4

Ganoderma spp., S2.11

Gao, F., S2.32

Gao, L., S2.53

Gao, R., 1103

Gao, X., S2.29

Garavaglia, T., S2.2

Garbelotto, M., 1141

Garber, N. P., S2.47

García-Domínguez, C., 862

García-Espinosa, R., S2.39

Garcia-Estrada, R. S., S3.11, S3.14

Garcia, J., S2.91

Garcia, K., S2.48

Garcia, M. O., S2.48

Garcia, R., S2.8

Garland-Campbell, K., 1130

Garrett, K., S2.50, S2.59, S2.145, S3.4, S3.8

Garrido, P., S2.159

Garzon, C., S2.33, S2.35, S2.99, S2.159, S2.176

Garzon, C. D., S2.52, S2.108

Garzón, L. N., 156

Gaskins, V. L., S2.70

Gassmann, W., S2.32

GATA factor, S2.90

Gautam, P., S2.48

Gautam, S., S2.24

Gauthier, A., 1035

Gaya, E., S2.26

Gazis, R., S2.48, S2.90

Geastrumia polystigmatis, S2.88

Gebauer, G., S2.64

Gee, J. C., 427

Geering, A., S2.94

Geering, A. D. W., S2.71

Geiser, D. M., 400, 1204, S2.71, S2.172

Geisler, M. M., S2.101

Geminiviridae, 1069, S2.114

Geminiviruses, characterization of replication fidelity, S2.2

GenBank, improving the veracity of sequence data in, S2.128

Gene expression profiling, of a compatible

interaction between Douglas-fir and Phellinus sulphurascens, 583

Gene knockouts, in Setosphaeria turcica using

Agrobacterium tumefaciens-mediated transformation, 641 
Genetics and resistance

association mapping of Septoria speckled leaf blotch resistance in barley breeding germplasm, 600

brassinosteroid enhancement of resistance to

Fusarium diseases in barley, 1260

colonization patterns of Pectobacterium

carotovorum subsp. brasiliense in potato, 1268

evaluation of Meloidogyne incognita resistance genes in Prunus, 833

explaining grapevine defense response to Esca, 1028

fine mapping of leaf rust resistance gene

LrZH84 in wheat, 169

functional analysis of Pid3-A4 by allele mining in common wild rice, 594

functional analysis of the glycosyl hydrolase gene promoter induced in resistant Sinapis alba, 841

fungal mitochondrial DNases and the activation of nonhost resistance, 81 gene expression profiling of a compatible interaction between Douglas-fir and Phellinus sulphurascens, 583

identification and mapping of a wheat resistance gene to and unadapted isolate of Colletotrichum cereale, 575

identification of blast resistance gene $P i-h k l$ in Japonica rice landrace, 1162

identification of Plasmopara viticola genes

involved in pathogenesis on grapevine, 1035

identification of resistance gene homologues in common bean, 156

identification of Rpg5 gene in rpg4-mediated wheat stem rust resistance, 1153

induced plant resistance by Ciborinia camelliae in Camellia, 725

lipid profiles in wheat cultivars resistant and susceptible to tan spot, 74

nonhost resistance of Arabidopsis thaliana against Alternaria alternata, 733

novel Capsicum gene inhibiting host-specific resistance to Phytophthora capsici, 472

population structure of Phytophthora capsici in pepper from China, 920

quantitative resistance to Fusarium head blight in elite spring barley, 1252

Genetic transformation

Agrobacterium tumefaciens-mediated transformation to create gene knockouts in Setosphaeria turcica, 641

of Plasmodiophora brassicae, 1052

polyethylene glycol-mediated transformation of Septoria musiva, S3.7

of tomato with a calcium signal modifier gene, S2.86

Genger, R. K., S2.25

Genome sequencing, Little cherry virus 1, 293

Gent, D., S2.38, S2.161

Gentit, P., 293

Geoglossomycetes, S2.64

Geomyces, S2.87, S2.119

Geosmithia morbida, S2.120, S2.163

Gerberich, K., S2.79

German, T. L., S3.7

Germin-like protein, S2.121

Germling communication, in Neurospora crassa, S2.187

Gessler, C., 1227

Gevens, A. J., S2.49, S2.129, S2.190, S3.5, S3.6

GFP-immunoelectron microscopy, S2.34

Ghimire, P., S2.87

Ghimire, S. R., S2.55

Ghosh, S., S2.129

Giacomelli, G., S3.16

Gia, J., S2.35

Gianessi, L., S2.49
Giant miscanthus (Miscanthus $\times$ giganteus)

foliar disease incidence associated with

Mississippi, S2.49

pathogenicity of fungi isolated from, S1.4

Giauque, H. E., S2.183

Gibberella zeae, cardendeazim resistance, S2.184

Gibson, D. M., 146

Giesbrecht, M., S2.49

Giesler, L., S2.83, S2.123, S3.7

Giesler, L. J., S3.3

Gilardi, G., 64

Gilbert, E., S2.97

Gilbertson, R. L., S2.12, S2.23, S2.106

Gillett, J. M., S2.127

Gilley, M. D., S1.4, S2.49

Gilligan, C. A., 1012

Gillis, M., S2.46

Giraldo, M. C., S2.186

Gitaitis, R., S1.3, S2.37

Giumbaud, J. F., S2.171

Gladieux, P., S2.49

Gladiolus rust resistance, S2.151

Glasa, M., 972

Glass, N. L., S2.186

Glassy-winged sharpshooters, transmission of

phage by, S2.16

Glazebrook, J., S2.87

Gleason, F. H., S2.68, S2.153

Gleason, M., S2.12

Gleason, M. L., 900, S2.65, S2.66, S2.83, S2.166,

S2.171

Gleeson, G., S2.82

Glen, M., S2.123

Glenn, A. E., 400, S2.11

Global Plant Health (GPH) program, S2.189

Globodera rostochiensis, S2.124

Glomus intraradices, S2.103

Glover, K., S2.4, S3.1

Glyceollin, 984

Glycoprotein $\mathrm{G}_{\mathrm{N}}, \mathrm{S} 3.7$

Glycosyl hydrolase gene, 841

Glynn, N., S2.53

Gochez, A. M., S2.50

Goellner, K., S2.77

Goenaga, R., S2.130, S3.16

Goldberger, B., S2.51

Goldberger, E., S2.58

Goldberg, N., S2.107, S2.138

Gold, S., S2.16

Gold Veined Oxalis (Oxalis corymbosa), S2.59

Golf course greens, cyst nematodes in, S2.103

Golino, D., S2.3, S2.9, S2.179

Goltz, J., S2.107

Gómez-Dorantes, N., S2.136

Gomez, L., S3.4

Gomez-Montano, L., S2.50, S3.8

Gómez, P., 1188

Gompertz models, 281

Goncalves, D. R., S4.2

Goncalves, F. P., S2.45

Goncalves-Zuliani, A. M. O., S2.50

Gong, Y., S2.180

Gonzalez, A., S2.140

Gonzalez, C., S2.16, S2.34

Gonzalez, D., S2.50

Gonzalez, J. P., S1.1

Gonzalez, M. C., S2.5, S2.59, S2.152

Gooch, M., 15

Goodin, M., S2.148

Goodwill, T. R., S2.56

Goodwin, S., S2.106

Goolsby, J. A., 1235, S2.162

Gooseberry vein banding associated virus

(GVBaV), S2.156

Gordon, T. R., 400, S2.191

Gossage, Z., S2.149

Goss, E. M., S2.50, S2.177

Gossen, B. D., 245

Goss's wilt and leaf blight of corn effect of residue management practices, S2.94 within field spatial and temporal analysis of, S2.35

greenhouse hybrid corn responses to, S3.6 resistance in dent corn inbreds, $\mathrm{S} 2.17$ screening the University of Illinois maize inbred collection for resistance, S3.6

Goswami, R. S., S2.51

Gottula, J., 1180, S2.51

Gottwald, T., S2.6, S2.17

Götz, M., 1252

Gougherty, A., S2.51

Gould, A., S2.51

Govindarajulu, A., 488

Gowda, C. L., S2.141

Goyer, C., 995

Grabau, Z., 34

Grabke, A., S2.43, S2.51

Grabosky, J., S2.51

Grabow, B. S., S3.4

Grabowski, M., S2.52

Graça, R. N., S2.123

Graf-Grachet, N., S2.52

Graft transmissible pathogens, biological indexing in citrus, $\mathrm{S} 3.14$

Graham, J. H., 409, S2.17, S2.52, S2.69

Grain mold, response of sorghum lines differing at the $P$ locus to, $\mathrm{S} 3.3$

Gramaje, D., 1058

Graminicolous anthracnose fungi, 575

Graminicolous downy mildews

biology of, S2.178

environmental metagenomics, S2.178

identification and diagnosis of

Peronosclerospora and Sclerophthora, S2.179 in North America, S2.178 taxonomy and phylogeny, S2.178

Granados, M. d., S2.52

Granger, D., S1.2

Granke, L., S2.52

Grant, J. A., S2.159

Grape berry moth, S2.58

Grape crown gall

distribution and detection in vines, S2.69

host-specific biological control by Agrobacterium vitis strain F2/5, 427 magnetic capture hybridization real-time PCR assay for detecting, 633

Grapefruit

development of transgenic cultivars with a calcium signal modifier gene, S2.152 effect of postharvest treatments on survival of Xanthomonas citri pv. citri, S2.6

XopAG effector-elicited hypersensitive reaction, $\mathrm{S} 2.50$

Grapemealy bug, S2.46

Grapevine (Vitis vinifera)

abiotic stresses affect Trichoderma harzianum T39-induced resistance to downy mildew, 1227

association of a DNA virus with red blotch disease, 1069

biological control of crown gall, S2.71 control of Botryosphaeria dieback with Glomus intraradices and Trichoderma spp., S2.103

defining the stages of infection of

Botryosphaeria dieback, S2.13

effect of rootstock on Xylella fastidiosa infection and sap phenolics, S2.154

effect of sap phenolics on in vitro growth of Xylella fastidiosa, S2.154

explaining the defense response to Esca, 1028

field treatment of bois noir with resistance inducers, 785

field trials for control of Phymatotricopsis omnivora, $\mathrm{S} 1.7$

fumonisin production by Aspergillus niger, S2.175 
functional analysis of stilbene synthase genes, $\mathrm{S} 2.32$

hydrogen peroxide accumulation and transcriptional changes in vines recovered from Flavescene dorée disease, 776 identification of Plasmopara viticola genes involved in pathogenesis, 1035

isolation of monoclonal $\mathrm{scFv}$ phage that binds to polygalacturonases of bacterial pathogens, S2.158

magnetic capture hybridization real-time PCR assay for detecting Agrobacterium vitis, 633

Pierce's disease in grafted cultivars, S2.126

quantitative phenotyping of powdery mildew resistance, $\mathrm{S} 2.22$

redleaf symptoms associated with a leafhopper-transmissible DNA virus, S2.114 survey of fungicide resistance in Botrytis cinerea, $\mathrm{S} 2.12$

Grapevine bois noir, field treatment with resistance inducers, 785

Grapevine deformation virus (GDefV), 1180

Grapevine fanleaf virus (GFLV) abolishing the nematode transmissibility of, S2.51

genetic variability, evolution, and biological effects of satellite RNAs, 1180

virus-vector-host interactions, S2.188

Grapevine leafroll associated virus 1 (GLRaV-1), $\mathrm{S} 2.46$

Grapevine leafroll associated virus 3 (GLRaV-3),

S2.9, S2.46

Grapevine powdery mildew

mechanisms of DMI resistance in, $\mathrm{S} 4.3$ ontogenesis of conidiation in, S2.93 real-time detection of airborne inoculum, S2.144

Grapevine red blotch-associated virus, 1069

Grapevine red blotch-associated virus (GRBaV) in California and U.S. vineyards, S2.140 in the Foundation Plant Services vineyards at UC Davis, S2.3

Grapevine red blotch disease, S2.4

Grapevine redleaf disease, $\mathrm{S} 2.114$

Grapevine vein clearing virus (GVCV), S2.61

Grapevine viruses

characterization by next generation sequencing, S2.124

prevalence in Georgia, S2.20

Grapevine yellows diseases, S4.1

Grass endophytes, dual mutualist-antagonist dynamics, S2.185

Gray leaf spot

induction of plant defenses by salicylic acid in perennial ryegrass, $\mathrm{S} 2.117$

of maize (see Cercospora zeae-maydis) potential to infect wheat in the U.S., S3.8 See also Magnaporthe oryzae

Gray, M. E., S2.3

Gray mold

of blueberry, control with compost tea, S2.20

of strawberry, monitoring for fungicide resistance in, $\mathrm{S} 2.43$

See also Botrytis cinerea

Gray's lily (Lilium grayi), S1.5

Gray, S. M., S2.65, S2.103

Great Smoky Mountain National Park, cryptic

viruses in the flora of, S2.125

Green manure crops effect on Verticillium dahliae, S2.98 Verticillium dahliae infection, S2.159

Green, T., S2.29

Gregory, N. F., 400, S2.36

Grey, T., S1.10

Gribaudo, I., 776

Gries, C., S2.97

Grigoriev, I., S2.18, S2.52, S2.75, S2.101, S2.106,

S2.121, S2.137, S2.146, S2.181

Grilley, M., S2.72
Grisham, M. P., S2.53, S2.84, S2.158

GroEL-like protein, S2.31

Groenewald, J. Z., S2.16, S2.153, S2.162

Gross, D. C., S2.79, S2.119, S2.125

Grossman, R. B., S2.109

Gross, T., 1153

Groth, D. E., S1.9

Groth-Helms, D., S2.120

Groundnut (Arachis hypogaea)

aflatoxin $\mathrm{B}_{1}$ contamination, $\mathrm{S} 2.104$

characterization of plant growth-promoting and disease suppressing abilities of actinomycete isolates, $\mathrm{S} 2.66$

See also Peanut

Grove, G., S2.93, S2.144

Grover, K., S3.16

Groves, C. L., S2.135

Groves, R., S2.171

Groves, R. L., S2.166

Growth pouch assays, 255

Grubisha, L. C., S2.36, S2.108

Grünwald, N. J., 851, 1204, S2.32, S2.41, S2.70,

S2.91, S2.139, S2.159

Grupe, A., S2.53

Gryganskyi, A., S2.18, S2.53

Gryta, H., S2.124

Guanica Dry Forest, S2.29

Guava stylar end-rot, S2.104

Gubler, W. D., S2.148

Gudmestad, N. C., 524, S2.69, S2.159, S3.3

Guenther, R. H., S2.85

Guerri, J., 1077

Guevara, G. G., S2.58

Gu, G., 381, S2.120

Gugino, B. K., 538, S2.68, S2.173

Gu, H., S2.34

Guiana Shield, S2.58

Guiderdoni, E., S2.13

Guignardia citricarpa

characterization and potential spread in the U.S., S2.40

characterization of the mating-type locus, S2.156

temperature/wetness modeling of pseudothecium maturation and ascospore release, 281

Guillermo, L. M., 488

Guimarães, E. A., S2.122

Guimarães, L. M., S2.107

Guimbaud, J. F., S2.171

Guitérrez-Barranquero, J. A., 1115

Gulya, T., S2.63, S2.91

Gummosis, 610

Gummy stem blight, S1.4

Gunasinghe, N., S2.53

Gundersen, B., S3.15

Guo, B., S2.183

Guo, J., 920, S2.84

Guo, L., S2.34, S2.53

Guo, Q., S2.61

Gurung, S., S2.54, S2.133

Gustafson, G., S2.10

Gut fungi, S2.55

Gutierrez Viveros, A. F., S2.54

Gutierrez, W., S2.180

Gut-inhabiting yeasts, S2.150

Guyanagaster necrorhiza, S2.74

Guzik, G., S1.2

Guzmán, G., S2.28

Guzmán-Plazola, R. A., S2.39

Gwinn, K. D., S2.84, S2.109

Hadwinger, L. A., 81

Hadziabdic, D., S2.54

Haegi, A., 802

Haelewaters, D., S2.54

Hagan, A., S2.79

Hagan, A. K., S2.19, S2.23, S2.54

Hagen, K., S2.158

Hagstrum, D., S3.4
Hajimorad, M., S2.73

Hajri, A., S2.170

Halbert, S. E., S2.55, S2.118, S2.177

Halbrendt, N. O., S2.55

Halkett, F., 190

Hall, B. A., S2.55, S2.165

Hall, C., S2.186

Hall, D., 15

Hall, D. G., S2.72

Hallen-Adams, H. E., S2.55

Halling, R., S2.104

Halling, R. E., S2.144

Halliwell-Asada pathway, S2.23

Halloran, J. M., S2.77

Hallwass, M., 436

Halterman, D., S2.49

Halvorson, J., S2.111

Halvorson, J. M., S3.4

Hamamouch, N., 175

Hamano, K., 960

Hambleton, S., S2.73, S2.108

Hameed, K., S2.18

Hamelin, R., S2.82

Hamelin, R. C., S2.32, S2.35, S2.42, S2.76, S2.143

Hamel, R., S2.44

Hamilton, G., S2.51

Ham, J., S1.2, S1.5, S1.7, S1.8, S1.9, S2.23

Ham, J. H., S1.6, S2.47, S2.192

Hammel, K. E., S2.95

Hammett, C., S2.82, S2.131

Hammond, J., S2.56, S2.188

Hammond-Kosack, K. E., 400

Hammond, R. W., S2.56

Hamm, P. B., 55, S2.37, S2.38, S2.96, S2.131

Han, B., S2.71

Handiseni, M., S1.5

Han, G., S2.56

Hanlin, R. T., S2.56, S2.59, S2.152

Hanna, J. W., S2.39, S2.123

Hanna, R., S2.65, S2.103

Hann-Soden, C., S2.49

Han, S., 135

Hansen, E. M., 190

Hans, G. R., S2.9

Hanson, L. E., 400, S2.56

Hanson, S., S2.2, S2.57, S2.136

Hao, L., S2.56

Hao, W., S2.56

Haplotyping assay, development for 'Candidatus

Liberibacter solanacearum', S2.159

Harakava, R., S2.34

Hard winter wheat, resistance to Puccinia striiformis f. sp. tritici, S2.97

Harman, G. E., S2.174

Harper, C. J., S2.180

Harper, S., S2.57

Harper, S. J., S2.31, S2.57

Harpophora maydis, detection assays, S2.30

Harrington, T. C., S2.43, S2.57, S2.65, S2.66, S2.107, S2.166

Harris, A. M., S2.76

Harris, J. L., S4.2

Harrison, H. F., S1.6

Hartman, G. L., 984, S2.24, S2.53, S2.163,

S2.164, S3.7

Hartung, J. S., 488, S2.124, S2.165

Harveson, R., S2.83, S2.162

Harveson, R. M., 1235

Hasey, J., S2.159, S2.163

Hassan, M., S1.6

Hassell, R. L., S2.32

Haudenshield, J. S., S2.53, S2.164

Hauff, R. D., S2.123

Hausbeck, M. K., S2.52, S2.101

Havis, N. D., 1108

Havstad, P., S2.57

Hawaiian forests, variation in fungal soil

community structure, S2.151

Hawaiian kipuka system, S2.47 
Hawes, M. C., 255, S2.147, S3.16

Hawkes, C. V., S2.161, S2.182, S2.183

Hayes, R. J., S2.21

Haygood, R., S1.5

Head smut, response of sorghum lines differing at

the $P$ locus to, $\mathrm{S} 3.3$

Healy, R., S2.135

Healy, R. A., S2.58, S2.93

Hebert, J. B., S2.58, S2.90

Heckert, S., S3.15

Hed, B., S2.58

Heikezijing, 1162

Hein, G., S2.143

Heiniger, R., S2.79, S2.106

Heinz, K. M., S2.16

Held, B. W., S2.11

Helianthus annuus. See Sunflower

Helicase dependent amplification, identification

of plant viruses, S2.9

Helmers, M., S2.56

Helms, T., S2.107

Hemibiotrophy, S2.186

Hemileia vastatrix, $\mathrm{S} 2.151$

Hemipteran-borne plant viruses, factors influencing the spread of, S2.179

Hemmer, C., S2.188

Hemstad, P., S2.22

Hendricks, K., S2.40

Henkel, T., S2.53, S2.58

Henkel, T. W., S2.135, S2.150

Henn, A., S1.1

Henne, D., S2.86

Henne, D. C., 1235, S2.130, S2.162

Henrissat, B., S2.146

Heppenheimer, E., S2.58

He, R., S2.44

Hernandez-Alvarez, Y., S2.59

Hernandez, J. L., S2.91

Hernandez-Martinez, R., S2.99, S2.103, S2.110, S2.152

Hernandez Nopsa, J., S2.59, S3.4, S3.8

Hernandez, S., S2.91

Herrera, C. S., S2.59

Herrera, F., S1.5, S2.59

Herrera, J., S2.18, S2.64, S2.115

Herrera-Rodriguez, G., S2.94

Hersh, M. H., S2.14

Hervey, K. L., S3.1

Hesler, Lexemeul Ray, S2.62

Hess, M., 1252

Heterobasidion spp., S2.131

Heterodera glycines

analysis of populations before and after corn rotation, S3.7

in North Dakota, S2.107

See also Soybean cyst nematodes

Heterodera spp., in golf course greens, S2.103

Heterothallism, 717

Hettich, R., S2.182

Heungens, K., 1169

Hevea, $\mathrm{S} 2.62$

Hevea brasiliensis. See Rubber tree

Hevea guianensis, delimitation of tropical endophyte Diaporthe species from, S2.134

He, W., 1162

Hewavitharana, S. S., S2.60

He, Z., 169

Hibbett, D., S2.48, S2.70, S2.90, S2.96, S2.101, S2.104, S2.108, S2.121, S2.180, S2.181

Hickory bark beetle, 565

Hickory decline, 565

Hicks, S., S2.60, S2.146

Hicks, S. L., S2.115

Higgins, R., S2.138, S3.9

High brix grape juice, $\mathrm{S} 2.58$

Highbush blueberry, Ralstonia salnacearum

infection, S2.112

High Plains virus (HPV)

evaluation of methods of detection, S2.9 incidence in wheat curl mites in maturing wheat heads, S2.143

Hildebrand, P. D., S2.8

Hilf, M. E., 545

Hill, A. L., S2.24

Hill, C. B., 984, S3.7

Hillman, B., S2.58, S2.90, S2.100

Hill, T., S2.101

Hilton, A., S2.60, S2.186

Himmel, P., S2.79

Himmelstein, J., S2.60, S4.2

Hinkel, L., S2.108

Hinton, D. M., S2.11

Hiraguri, A., 513

Hirneisen, K. A., 389

Hirooka, Y., S2.125

Hirsch, R. L., S2.60, S2.120

Hladky, L. L., 501, S2.160

HLB. See Huanglongbing

Hliebieh, K., S2.188

Hoang, Q., S4.2

Hobbelen, P. H. F., 690

Hobbs, H. A., 941, S2.164

Hochmuth, G. J., S2.12

Ho, C. Y., S2.180

Hodge, K. T., S2.60

Hoenisch, R., S2.163

Hoffman, M. T., 15

Hogenhout, S., S2.171

Hog slurry solids, effect on potato early dying, S2.98

Hohenlohe, P. A., S2.74

Holbrook, C. C., S1.9

Holden, N. J., 333

Holden, S. R., S2.183

Holguin, O., S2.138

Holland, B., S1.2

Holland, R., S1.9, S2.80

Hollier, C., S1.6, S2.71

Hollingsworth, C. R., S2.124

Hollingsworth, T., S2.182

Holmberg, A. M., S2.136

Holton, T., S2.76

Homalodisca vitripennis, S2.16

Honesty, S., S2.61

Hong, C., S2.33, S2.56

Hong, J., S2.61

Hong, J. C., 409

Honig, J. A., S2.100

Hooftman, R., S2.94

'Hope' wheat cultivar, 575

Hopkins, A. A., S2.142

Hopkins, K. L., S2.8

Hops, powdery mildew on cultivars with R6based resistance, $\mathrm{S} 2.38$

Hop stunt viroid (HSVd), S2.82

Hora Junior, B. T., S2.61, S2.62

Hordeum vulgare. See Barley

Hordeum vulgare subsp. spontaneum, identification of Rhizoctonia root rot resistance in, $\mathrm{S} 2.3$

Horn, B. W., S1.8, S2.106

Horse chestnut bleeding canker, S2.67

Horvath, B., S2.76

Horvath, D., S2.131

Hosta virus X (HVX), S2.9

Host-parasite interactions, genomic and molecular mechanisms for crop protection, S2.183

Host-specific biological control, of grape crown gall by Agrobacterium vitis strain F2/5, 427

Host-specific disease resistance, novel Capsicum gene inhibiting resistance to Phytophthora capsici, 472

Host-specific disease response, characterization of a Xanthomonas citri subsp. citri variant that triggers, 555

Hotchkiss, M. W., S2.17

Hou, L., S2.42
House fly (Musca domestica), 373, S2.185

Housladen, H., 1252

Hou, Y., S2.184

Hoy, J. W., S2.10, S2.53, S2.54

HrpL regulon, in Pantoea agglomerans pv. gypsophilae, S2.24

Huang, G., 175, S2.129

Huang, J., 1162

Huang, L. L., 927

Huanglongbing (HLB)

assessment in Dominica, S2.141

evaluation of HLB tolerance in Citrus, S2.118

heat treatment, 15

root loss from, S2.69

See also 'Candidatus Liberibacter asiaticus'; Citrus huanglongbing

Huang, P. C., S2.62

Huang, Q., S2.140

Huang, Y. C., S2.28

Huang, Y. L., S2.62, S2.150

Hückelhoven, R., 1252

Huffman, V., S2.129

Huggins, D., 1130

Hughes, K. W., S2.62, S2.63, S2.113

Hughes, M., S2.40

Hughes, T., S2.130

Hugh, G., 1108

Huguet-Tapia, J. C., S2.18

$\mathrm{Hu}, \mathrm{H} ., \mathrm{S} 2.62$

$\mathrm{Hu}$, J., 920

$\mathrm{Hu}, \mathrm{L} ., 1252$

Hulbert, S., S2.36, S2.164

Hulcr, J., S2.71

Hulvey, J., S2.63, S2.73, S2.126

Human-associated microbiome, S2.55

Humann, J., S2.93

Human noroviruses, survival on spinach during preharvest growth, 389

Humann, R., S2.63

Human pathogens on plants consequences of disrupting Salmonella AI-2 signaling on interactions with soft rots, 352 designing a multidisciplinary research strategy, 306

E. coli $\mathrm{O} 157: \mathrm{H7}$

colonization and internalization, 333 plant immunity induced by $\mathrm{O} 157: \mathrm{H} 7$ and Salmonella enterica Typhimurium SL1344, 326

transfer to spinach by house flies, 373 focus issue on food safety, 304 interactions with plants, S2.125, S2.184 norovirus surrogate survival on spinach during preharvest growth, 389

novel strategies to reduce outbreaks, S3.9

Salmonella enterica effect of resident leaf bacteria on survival, 34 identification of genes with a role in persistence on lettuce leaves, 362

Salmonella enterica Typhimurium effect of soil management on movement in tomato plants, 381

plant immunity induced by strain SL1344 and $E$. coli $\mathrm{O} 157: \mathrm{H} 7,326$

Salmonella interactions with plants and associated microbiota, 316

Humber, R. A., S2.53

Hummel, Z. J., S2.136

Hum-Musser, S., S2.115, S2.149

Humphris, S., 333

Hung, R., S2.63, S2.78

Hung, T. H., S2.82

Hurburgh, C., S2.175

Hurd, K. M., S2.42

Hussey, R. S., 175, S2.129

Husson, C., 190

Hustad, V. P., S2.64

Hutchinson, M. I., S2.64, S2.115 
Hutin, M., S2.170

$\mathrm{Hu}, \mathrm{Y} ., \mathrm{S} 2.62, \mathrm{~S} 2.131$

Hwang, H.-H., 888

Hwang, S. F., 245, 1052

Hwu, F. Y., S2.64

Hyde, K. D., S2.89, S2.150, S2.172

Hydrogen peroxide

accumulation in grapevines recovered from Flavescene dorée disease, 776

in rice infected with Rice black streaked dwarf virus, S2.163

Hydroxycinnamic acids, S2.86

Hynes, R. K., 245

Hynson, N., S2.64

Hyodo, A., 960

Hyperparasites, influence on the population

structure of Cryphonectria parasitica, 1280

Hypersensitive response

elicited by the TNV coat protein in Nicotiana spp., S2.43

XopAG effector-elicited in grapefruit, S2.50

Hypervariable ITS sequences, among isolates of

Ceratocystis fimbriata, S2.56

HYT A, S3.12

HYT B, S3.12

Ibarra Caballero, J. R., S2.64, S2.65

Ibarra, M. A., S2.117

ICRISAT, S2.141

Idowu, J., S3.14, S3.16

Idris, A., S2.5, S3.13

IFS2 gene, 984

I gene, S3.13

Igwe, D., S2.65

IITA-ARS maize lines, accumulation of aflatoxin in, S1.2

Ikerd, J. L., S1.6, S2.75

Iliuk, A., S2.81

Imazalil resistance, genotyping in Penicillium

digitatum isolates, $\mathrm{S} 2.72$

Imidacloprid, in control of citrus canker, S2.52

Immunomagnetic separation (IMS), 633

Impatiens downy mildew management, S2.109

Impatiens necrosis spot virus (INSV), S2.9

Inch, S., S2.114

Indiana, A., S2.171

Induced host resistance

by Ciborinia camelliae in Camellia, 725

in the suppression of clubroot on canola by Serenade, 245

Induced systemic resistance (ISR), S2.29

abiotic stresses affect Trichoderma harzianum T39-induced resistance in grapevine, 1227

Infrared spectroscopy, early monitoring of stripe

rust and leaf rust on wheat, S2.80

Inglis, D. A., S3.15

Ingram, D., S1.1

Ingram, R. J., S1.5

Ingram, T., S1.2

Ingram, T. W., S1.5

Inguagiato, J., S2.65

Inoue-Nagata, A. K., 436

Inoue, Y., 575, S2.174

Insect-transmitted bacterial diseases, S2.171

Integrated pest management (IPM)

documenting the impact of, S2.190

foliar fungicides with hybrid corn, S2.88

in the western U.S., S3.13

Integrated Pest Management Innovation Lab, S2.42

Internal transcribed spacer (ITS)/cytochrome $c$

oxidase subunit I (COI), 1103

International Code of Nomenclature (ICN), S2.172

International Peanut Genome Initiative (IPGI),

S2.183

Internet-served forecast systems, for mummy

berry disease, $\mathrm{S} 2.8$

Inter-simple-sequence repeats (ISSRs) genetic structure of Colletotrichum gloeosporioides inferred by, 182 specific discrimination of Fusarium proliferatum, S2.99

Invasive pathogens, Caribbean pathways, S3.15

Investigative plant pathology, S2.33

Ionescu, M., S2.148

Ipcr gene, 472

Iprodione, genetic mechanisms of decreased

sensitivity in Sclerotinia homoeocarpa, S2.126

Iprodione resistance, in isolates of Botrytis

cinerea from small fruits, S2.51

Iriarte, F. B., S3.4

Iris yellow spot virus (IYSV), S2.142

Ironwood tree decline, S2.10, S2.128

Irrigation water

plant health risks from Phytophthora-infested water, S1.7

three novel species of Phytophthora from Mississippi, S2.164

ultraviolet treatment, S2.69

Isakeit, T., S1.7, S2.65

Ishimaru, C. A., S2.87

Islam, M. A., 583

Islas, C., S2.3

Ismail, S. I., S2.65, S2.66

Issac, Y., S2.99

ITS/COI, 1103

ITS rDNA analysis

of fungal succession, S2.20

of Usnea, S2.149

ITS-RFLP analysis, 479

Iturins, 146

Ivors, K., S1.7, S2.47, S2.85

Jackson, A. K., S2.24

Jackson, R., S2.67

Jacob, S., S2.66

Jacobs, J., S2.66

Jacobs, J. J., S2.108

Jacobs, J. L., S2.123, S2.157

Jacobs, J. M., S2.32, S2.66

Jacques, M. A., S2.170, S2.171

Jahn, M. M., S2.8

Jaime, R., S2.66, S2.175, S3.13

Jain, M., S2.66

Jalan, N., S2.67, S2.119

Jamann, T., S4.3

James, S. L., S2.67

James, T. Y., S2.15, S2.34, S2.45, S2.67, S2.68, S2.146, S2.153

Janisiewicz, W. J., S2.67, S2.70

Jansen, M., S2.128

Jansky, S., S2.49

Jansson, J., S2.182

Japonica rice landrace, blast resistance gene

Pi-hkl, 1162

Jardine, D., S2.123, S2.175

Jargeat, P., S2.124

Jarosz, A. M., 1280, S2.127

Jayaraman, J., S3.11

Jayasundera, K. B., S2.81

Jaynes, J., S2.127

JAZ, S2.105

Jeannotte, R., 74

Jecmen, A. C., S1.10

'Jefferson' hazelnut, S3.15

Jeffers, S. N., S2.36, S2.128, S2.151

Jeger, M. J., 108, 768

Jenkins, D., S2.72

Jenkins, D. M., 1220

Jenkinson, T. S., S2.15, S2.67

Jeong, K., S2.67

Jerez, D., S3.12

Jerônimo, G. H., S2.68, S2.153

Jesse, L., S3.3

Jesus, A. L., S2.68, S2.153

Jett, L., S2.118

Jeyaprakash, A., S2.141

Jhala, R., S2.138, S3.9

Jia, H., S2.62, S2.167
Jia, M., S2.24

Jia, M. H., S2.78, S2.88

Jiang, D., 750

Jiang, G., 594

Jia, Y., S2.78, S2.88, S2.124, S2.168, S2.184

Jiménez, A., S2.68

Jiménez-Díaz, R. M., 1058

Jimenez-Gasco, M. D., S2.11, S2.55, S2.68, S2.173

Jiménez-Gasco, M. M., 400, 479, 538

Jiménez, P., S2.14, S2.23, S2.68, S2.122, S2.151

Jin, H., S2.187

Jin, X., S2.68

Ji, P., S1.4, S2.43, S2.162

Joardar, V., S2.144

Johansen, R. B., S2.69

Johnson, C., S2.69, S2.159, S2.187

Johnson-Cicalese, J., S2.114

Johnson, D. A., 55, 445, S2.149, S2.159, S3.17

Johnson, E. G., S2.69

Johnson, G. C., S2.36

Johnson, K. B., S2.150

Johnson, K. L., 427, 633, S2.69

Johnson, L., S2.67, S2.87

Johnston, M. T., S2.23

Johny, A., S2.147

Jones, D., S2.141

Jones, I., S2.67

Jones, J., S1.3, S2.54, S2.67, S2.72, S2.167

Jones, J. B., 228, 237, 409, S2.50, S2.62, S2.131, $\mathrm{S} 2.146, \mathrm{~S} 2.168$

Jones, L., 15, S2.69

Jones, S., S2.141

Jonkers, W., S2.53, S2.186

Jordahl, J., S2.63, S2.91

Jordan, R., S2.165

Jordan, S. A., S3.5

Jordhal, J., S2.107

Joseph, L., S2.134

Jo, Y., S1.2, S1.5, S1.8

Juarez, M., 1188

Juglans cinerea (butternut), S2.66

Juglans nigra (black walnut), S2.120

Juglans regia (English walnut), S2.163

Jumpponen, A., S2.20, S2.50, S2.86, S2.107,

S2.182, S3.4, S3.8

Jung, E., 1020

Jung, G., S2.5, S2.63, S2.73, S2.126

Juniperus deppeana, S2.62

Jurgens, A. G., S2.70

Jurgens, J. A., S2.95

Jurick, W., S2.67

Jurick, W. M., S2.70

Justo, A., S2.70, S2.90, S2.108

Juzwik, J., 565, S2.120

Kabbage, M., S2.79

Kachapulula, P. W., S2.70

Kadooka, C. Y., S2.123

Kaewnum, S., 427, 633

Kaiser, M., S2.51

Kamas, J., S1.7, S2.126

Kamath, N., S2.145

Kaminaka, H., 733

Kaminski, J. E., S2.81

Kamvar, Z. N., S2.70

Kanenga, K., S2.104

Kang, E. L., 216

Kang, H., S2.71

Kang, H. G., S2.19, S2.70

Kang, S., 400, 1204, S2.74

Kang, Z. S., 927

Kapanigowda, M. H., S2.11

Karasev, A., S2.38, S2.42

Karasev, A. V., S3.13, S3.15

Karki, H. S., S1.6

Karlovsky, P., 682

Karstedt, F., S2.71

Kashefi, J. N., S2.15

Kassatenko, I., S2.131 
Kassem, M. A., 1188

Kasson, M. T., S2.71

Kasugamycin, sensitivity of Erwinia amylovora to, S2.70

Katan, J., 23

Katsoudas, E. J., S2.147

Kaufman, J., S3.2

Kaur, H., S2.105

Kaur, K., S1.6, S2.71

Kawaguchi, A., S2.71

Kawasaki, Y., S2.72

Keeling, J. W., S2.161

Keesling, J. E., S2.55

Keith, L. M., S3.14

Keller, K. E., S2.72

Kellerman, M., S2.72

Keller, N. P., S2.19, S2.62

Kelly, C. M., S2.161

Kelly, J. D., S2.1

Kelly, M., S2.136

Kemerait, R., S1.1, S1.4, S2.79

Kenerley, C., S2.29, S2.31, S2.99

Kennedy, P., S2.182

Kennelly, M., S2.50, S3.4, S3.8, S3.9

Kentucky bluegrass (Poa pratensis), spatial

patterns of ergot in seed fields, S2.37

Keremane, M. L., S2.55, S2.72, S2.118, S3.14

Kermack-McKendrick equation, 204

Kernaghan, G., S2.92

Kerns, J., S2.121

Kertho, A. O., S3.5

Kesanakurti, P., S2.73

Kessler, D., S2.73

Keune, J. A., S2.144

Khadgi, A., S1.6

Khalaf, A., S2.132

Khallouk, S., 833

Khan, A., S2.4, S2.73

Khang, C. H., S2.186

Khankhum, S., S1.6, S2.2, S2.73

Khan, M., 1260

Khan, M. F. R., S2.73

Khatabi, B., S2.73

Khiook, I. L. K., 1028

Kholina, N. A., 984

Kidarsa, T., S2.28

Kiguchi, S., 575

Kim, D., 74

Kim, H., 1045

Kim, H.-S., 1204

Kim, J., S1.2, S2.55

Kim, K. H., S2.74

Kim, M. J., S2.45

Kim, M. S., S2.39, S2.74, S2.123

Kim, S. H., 1204, S2.74

Kim, T., S2.71

Kim, Y., S2.71

Kim, Y. S., S2.71

Kinard, G., S2.116

King, K., S2.136

Kinkel, L. L., 34

Kinoshita, A., S2.58

Kinzer, K. M., S2.74

Kipuka system, S2.47

Kirkpatrick, B., S2.158, S2.191

Kirkpatrick, T., S1.5

Kiss, L., 623

Kistler, C. H., S2.53

Kistler, H. C., 400

Kivlin, S. N., S2.182

Kiwi (Actinidia deliciosa), Ceratocystis wilt in

Brazil, S2.43

Klaassen, V., S2.3

Klein, E., 23

Kleinhesselink, K., S2.140

Kleinhofs, A., S2.164

Klein, R., S2.83

Klessig, D. F., S2.19, S2.70

Kline, W. L., S2.89
Klironomos, J., S2.181

Kloepper, J. W., S2.168

Klooster, M. R., S2.36

Klopfenstein, N. B., S2.39, S2.74, S2.123

Klosterman, S. J., 268

Kluepfel, D., S2.140

Knerr, J., S2.8

Kniel, K., 389, S2.90, S2.185

Knight, C. A., S2.74

Knudsen, G. K., S2.43

Knut, S. A., S2.9

Kobayashi, D., S2.14, S2.112, S2.121

Koch, A. R., S2.35

Koch, K., S2.155

Koch, R. A., S2.74

Koch's postulates, S2.87

Kocsubé, S., S2.142

Kodama, M., 733

Koebnik, R., S2.13, S2.67, S2.170

Koenen, B., S2.94

Kogel, K. H., S2.70

Kohler, A., S2.75

Kohn, J. S., S2.147

Koike, S. T., S2.142

Kokalis-Burelle, N., 792, S2.61

Kolmer, J., S2.84

Kolomiets, M. V., S2.19, S2.29, S2.62

Kolomiets, T., S2.15

Komar, H., S2.74

Konkol, J., S2.40, S2.71, S2.114

Kon, T., S2.23

Koopmann, B., 682

Koopman, T. A., S2.75

Korean oak wilt, S2.74

Korejo, F., S2.38

Korth, K. L., S1.6, S1.9, S2.76, S2.121

Kosta, K., S2.129

Kouadio, L., S2.38

Kousik, C. S., 1243, S1.6, S2.75

Kowbel, D., S2.186

Kowbel, R., S2.131

Kozanitas, M., 1141

Krakowsky, M., S1.2

Krauter, P. C., S2.16

Kreiser, B. R., S2.97

Kressin, J., S2.134

Kretzschmar, T. G., S2.99

Kreuze, J. F., S2.1

Krieger, I., S2.99

Kringler, J., S2.107

Krings, M., S2.180

Kroese, D., S2.139

Kromann, P., S2.145, S3.8

Kropf, U., 682

Kroupitski, Y., 362

Krska, R., S2.175

Krüger, E., 1001

Kruger, G., S2.84

Kruijt, M., S2.140

Kryvoruchko, I., S2.92

Kubheka, G. C., 1268

Kubota, R., 1220, S2.72, S2.128

Kuldau, G., 400, 538, S2.189

Kumar, L., S2.65, S2.103

Kumar, T. K., S2.93

Kund, G., S2.72

Kundu, S., S3.14

Kunta, M., S2.75, S2.86

Kuo, A., S2.75

Kurle, J., S3.2, S3.5

Kuske, C., S2.115

Labbe, J., S2.18

Labbe, N., S2.109

Labeda, D., S2.113

Laboulbeniales, S2.54

LaButti, K., S2.18

Labyrinthula terrestris, S2.107

Labyrinthulids, S2.107
Laccaria bicolor, S2.52

Lactuca sativa. See Lettuce

Lacy, G. H., 237

Lagenaria siceraria. See Bottle gourd

Lagopodi, A. L., S2.15

LaGreca, S. A., S2.60

Laguna, G., 129

Lahaye, T., S2.131

Lahlai, R., 245

Lai, E.-M., 888

Lakshman, D., S2.76, S2.98, S2.121

Laliberté, J. F., S2.188

Lamarche, J., S2.76, S2.143

Lambert, C., 1028

Lambertella sp., S2.160

Lambertini, C., S2.67

Laminated root rot (LRR), 583

Lamka, G., S2.174

Lamour, K., 920, S2.42, S2.165

LAMP. See Loop-mediated isothermal amplification

Lamppa, R., S2.111, S3.4

Lamptey, J. N., S2.12

Landa, B. B., 479, 1058

Laney, A. G., S1.6, S2.76

Lange, H. W., S2.76

Langenbach, C., S2.77

Lang, J. M., S2.10, S2.76, S2.89, S2.152

Langlois, P., S2.76

Langsat (Lansium domesticum), corky bark disease in Hawaii, S3.14

Langston, D., S1.3, S2.37

Lan, P., S2.76

Lansium domesticum (langsat), S3.14

Lan, Y., S2.184

Lapaire Harmon, C., S2.77, S2.153

Lapato, D., 1180

Lapitan, N., S2.87

LaPlant, K. E., S2.46

Large patch, management in zoysiagrass, S1.8

Larkin, R. P., S2.77

Larsen, M. M., S2.41

Larson, E., S1.1, S2.77

Lashomb, J., S2.51

Lasiodiplodia theobromae, S2.110, S2.152

Laskaris, P., S2.77

Laski, P. J., S2.26

Late blight. See Alternaria late blight of pistachio; Potato late blight; Tomato late blight

Late wilt of corn, conventional PCR and qPCR assays to detect, S2.30

Lauber, E., S2.170

Laughlin, D., S1.7

Laurel wilt

on avocado, S2.114, S3.15 epidemiological study, S2.40

Lawrence, A., S2.87

Lawrence, C. B., 741

Lawrey, J., S2.186

Lazarus, K. L., S2.146

Leach, J., S2.87

Leach, J. E., 306, S2.10, S2.19, S2.30, S2.76, S2.89, S2.92, S2.148, S2.152

Leach-Kieffaber, A. N., S3.7

Leaf rust of wheat. See Wheat leaf rust

Leaf scald resistance, evaluating sugarcane for, $\mathrm{S} 2.54$

Leaf-shredding, as a component of integrated management for apple scab, S2.154

Leaf spot bacterial leaf spot of lettuce, S2.21 (See also Xanthomonas perforans characterization of difference between early and late epidemics in response to prescription fungicide programs, S1.4 cherry leaf spot, S2.191

frogeye leaf spot, 1045 (See also Cercospora sojina)

of lowbush blueberry, effect of management systems on, S2.7 
narrow brown leaf spot, S1.6, S2.168 (see also Cercospora janseana)

of peanut, monitoring with visual assessments and canopy reflectance, $\mathrm{S} 1.8$

Septoria leaf spot, S2.101

sugar beet leaf spot, S2.21

white leaf spot, $\mathrm{S} 2.53$

See also Gray leaf spot

Leafy greens

biocontrol of enteric pathogens, S2.90

occurrence and distribution of pathogenic and indicator bacteria, $\mathrm{S} 2.89$

Leandro, L., S2.56, S2.117

Leandro, L. F., 822, S2.2, S2.39, S2.40, S2.143

Leandro, L. L., S2.31

Leaño, E. M., S2.153

Lear, M., S4.2

Leaves, effect of resident bacteria on Salmonella

enterica survival, 341

LeBoldus, J. M., S2.116, S3.7

Lecompte, F., 261

Leeder, A., S2.186

Lee, I. M., S2.26

Lee, J. A., S2.55

Lee, M. H., S2.84

Lee, M. W., S2.78

Lee, R., S2.156

Lee, R. A., S2.78

Lee, R. F., S2.55, S2.72, S2.118, S2.177, S3.14

Lee, S., S2.63, S2.78

Lee, S. H., S2.155

Lee, S. L., S2.54

Lee, Y.-H., 1204

Lee, Y.-L., 888

Lefevre, E., S2.150

Legge, R., S2.55

Legg, J., S2.145

Legg, J. P., S3.8

Legumes, unraveling anthracnose pathogens in, $\mathrm{S} 2.33$

Lei, C., S2.89

Leifsonia xyli subsp. xyli, S2.84

Leinauer, B., S2.107

Leisner, S., S2.122, S2.188

Lemaire, O., S2.188

Leng, Y., S2.78

Lennox, C. L., S2.75, S2.154

Lentinula edodes (shiitake), S2.105

Leonberger, A., S2.79

Leon-Felix, J., S3.11

Leon-Galvan, F., S2.112

Leptosphaeria coniothyrium, $\mathrm{S} 4.3$

Lesion nematode (Pratylenchus vulnus),

management on walnut, S2.159

Leslie, J., S3.4

Leslie, J. F., 400, S2.98, S3.4

Lesniak, K. E., S2.79

Letcher, P. M., S2.34, S2.115, S2.130

Lethal Yellow (LY), S2.177

Lettuce (Lactuca sativa)

effect of HYT A and HYT B on fungal pathogen growth, S3.12

evaluation and relative susceptibility to Tomato spotted wilt virus and Fusarium wilt, S3.17

identification of Salmonella enterica genes with a role in persistence on leaves during cold storage, 362

immunity induced by $E$. coli $\mathrm{O} 157: \mathrm{H} 7$ and Salmonella enterica Typhimurium SL1344, 326

internal colonization of leaves by Xanthomonas campestris pv. vitians, $\mathrm{S} 2.21$

presence and relative incidence of viruses infecting, S2.112

root colonization and internalization by $E$. coli $\mathrm{O} 157: \mathrm{H7}, 333$

Lettuce necrotic stunt virus (LNSV),

reclassification, 501, S2.160
Leung, H., S2.19, S2.89

Leveau, J., S2.84

Leveillula taurica, detection and quantification of growth in pepper leaves, 623

Levesque, A., S2.73, S2.178, S2.179

Lévesque, C. A., 43

Levi, A., S2.144

Levy, F., S1.5

Levy, J. G., S2.79, S2.164, S2.165

Levy, L., 488, S2.20, S2.124, S2.167

Lewis, C., S2.178

Lewis, C. T., S2.73

Lewis, J., S1.7

Lewis, M. H., S2.79, S2.106

Lewis, R., S2.129

Lewis, S. E., S2.79

Liang, J., S2.81

Liang, M., 135

Liang, X., S2.81

Liao, B., S2.183

Liao, H. L., S2.53, S2.82

Liao, J. Y., S2.82

Liberibacter crescens, S2.66

Li, C., 175

Lichenicolous fungi, S2.186

Lichens

ITS rDNA and protein-coding genes in Usnea, S2.149

lichen symbioses compared to pathogenic symbioses, S2.185

obligately lichen-associated fungi, S2.186

Lichter, F., S2.82

Lickey, E. B., S2.63

Liesner, L., S3.13

Li, F., S2.76

Ligarreto, G. A., 156

Lignicolous freshwater ascomycetes, S2.59

Lignicolous marine ascomycetes, S2.5

Lignocellulose-degrading enzymes, S2.181

Li, J., S2.80, S2.84

Lilium grayi. See Gray's lily

Lilleskov, E., S2.181

Lily (Lilium)

identification of viruses in small-farm cut flower crops, S3.12

peptide with antimicrobial potential, S2.82

Lima bean (Phaseolus lunatus)

endornavirus infection, S2.2

improving management resources to benefit the Mid-Atlantic region, S2.36

Lima, C. S., S2.136

Lim, H. S., S2.188

Linares, S., S2.83

Lin, B., S2.82

Lin, C. H., S2.82

Lin, C. Y., S2.82

Lindley, L., S2.49

Lindner, D. L., S2.108, S2.119

Lindow, S., 341

Lindow, S. E., S2.25, S2.148, S2.186

Ling, K. S., S2.80

Lin, H., 524, S2.104, S2.125, S2.132

Linkmeyer, A., 1252

LINK technology, S2.20

Linn, B. F., S2.39

Lin, N. C., S2.82

Liou, R. F., S2.28, S2.64

Lipid profiles, in wheat cultivars resistant and

susceptible to tan spot, 74

Lipoxygenase, S2.62

9-Lipoxygenase mutants, S2.29

Li, R., S2.1, S2.76, S2.80, S2.116, S2.156

Li, S., 594, S2.80, S2.83

Li, S.-J., 135

Li, T., 594

Little cherry virus 1 (LChV1), genome

characterization and association with Shirofugen stunt disease, 293

Little, C. R., S2.11, S3.2
Little, E., S2.15, S2.189

Liu, B., S2.83, S2.84

Liu, C., S2.123

Liu, D., 169

Liu, F., S2.33, S2.168

Liu, G., S2.168

Liu, H., S2.30

Liu, J., S2.13, S2.31, S2.83, S2.84

Liu, K. L., S2.115

Liu, M., S2.84

Liu, Q., S2.83

Liu, T., S2.116

Liu, T. H., S2.84

Liu, W., S2.84, S2.87, S2.116

Liu, X., 920, S2.183

Liu, Y., 594, 920, S4.2

Liu, Z., S2.20, S2.127

Livingston, D., S2.133

Li, W., S2.80

Li, X., 169, 594, S2.51, S2.131

Li, X. L., S2.80

Li, Y., S2.79, S2.81

Li, Z., 169

Lloyd, M., S2.85

Loblolly pine (Pinus taeda) ectomycorrhizal community, S2.160 effect of altered climate scenarios on Loblolly pine decline, s2.26

Locoweeds, S2.12

Lodge, D. J., S2.53, S2.63, S2.85, S2.123

Lodge, J., S2.28

Loeb, G., S2.46

Logistic regression models, predicting Fusarium head blight epidemics, 906

Logrieco, A., 400, S2.175

LOH2 gene, 733

Loline alkaloids, evolution, S2.109

Lolium arundinaceum. See Tall fescue

Lolium latent virus (LoLV), S2.188

Lolium multiflorum, epiphytic survival of

Pseudomonas sp. on, S1.3

Lolium perenne. See Perennial ryegrass

Lommel, S. A., S2.85

Longcore, J. E., S2.15, S2.67, S2.130

Longway, L. J., S2.85

Lookabaugh, E., S1.7, S2.85

Loop-mediated isothermal amplification (LAMP) detection of Burkholderia glumae, S2.23

detection of Colletotrichum acutatum on strawberry, S2.166

detection of Gooseberry vein banding associated virus, $\mathrm{S} 2.156$ detection of Leifsonia xyli subsp. xyli, S2.84 detection of Pseudomonas fuscovaginae, S2.10

detection of Xanthomonas oryzae, S2.76

of the micA gene in Clavibacter michiganensis subsp. michiganensis, 1220 real-time detection of airborne Erysiphe necator inoculum, S2.144

Loper, J., S2.28, S2.121

Lopes, C. A., S2.126

Lopez, M., S2.85

Lopez, P. N., S2.109

López-Ramirez, M. A., S2.123

Lopez, S., S2.102

Loria, R., S2.45, S2.77

Loropetalum chinense, S2.141

Loropetalum stem canker, S2.141

Loschinkohl, C., S2.1

Lothamer, K., S2.86, S2.182

Lott, C., S2.86

Louws, F. J., S2.134, S2.147

Louzada, E., S2.75, S2.86, S2.152

Lowbush blueberry

effect of management systems on stem and leaf spot diseases, S2.7

Internet-served forecast system for mummy berry disease, S2.8 
Lowe, T. M., S2.86

Lowry, D., S2.34, S2.44

LOX2, S2.62

Loyd, A. L., S1.7

Lozovaya, V. V., 984, S3.7

Lr44 gene, 169

$L r G 98$ gene, 169

LrXi gene, 169

LrZH84 gene, 169

LSU analysis, of fungal succession, S2.20

Lubberstedt, T., S2.7

Luby, J., S2.22

Lu, C., S2.84, S2.87

Lucas, G. C., S2.6

Lucas, S., 1028

Lücking, R., S2.186

Lueschow, S. R., S2.87

Lu, G., 400

Luis, P., 1035

Lujan, P., S3.14, S3.16

Luna, E., S2.87

Luna, M., S3.11

Luo, H., S2.184

Luo, J., S2.96, S2.173

Luo, M., S1.4, S2.45

Luoma, D. L., S2.48, S2.85

Luongo, L., 802

Luo, Y., S2.81

Lupien, S., S2.8, S2.37

Lu, Q., S2.87

Lu, S., S2.35, S2.87, S2.168, S2.184

Luster, D. G., S2.18, S2.179

Lutz, L., S2.122

Lutzoni, F., S2.26, S2.113, S2.149, S2.150,

S2.161, S2.185

LuxS-dependent auto-inducer (AI)-2 signal, 352

Lu, Y., S2.87

Lv, H., 920

Lv, Q., 594

Lygin, A. V., 984, S3.7

Lyons, C. W. P., S2.88

Lysobacter enzymogenes strain C3, S2.168

Lysoe, E., 400

Lytle, M., S3.16

Mabura Ecological Reserve, S2.150

MacCoss, M. J., S2.65

Machado, J., S3.9

Machado, J. C., S2.113, S2.133

Machado, J. D. C., S2.166

MacHardy, W. E., S2.154

Maciel, J. L. N., S3.5

Mackey, D., S2.47

Macrofungi Collection Consortium, S2.45, S2.144

Macrophomina phaseolina

detection with SCAR assay in cluster bean, S2.25

efficacy of methyl bromide alternatives against, S2.130

glyceollin in soybean plant defense against, 984

identification of genes involved in phaseolinone biosynthesis, S2.101

Macrophomina phaseolina resistance, evaluation

of soybean varieties for, $\mathrm{S} 2.130$

Madden, L., S2.33

Madden, L. V., 906, S2.7, S2.173

Madeiras, A. M., S2.88

Maes, M., 1169

Maffia, L. A., S2.61, S2.62, S2.100, S2.137

Magain, N., S2.149

Magdama, F., S2.55, S2.68

Ma gene, 833

Magill, C. W., S2.178

Magnaporthe oryzae, 594

characterization and targeted deletion of Bin1, S2.143

GATA factor control of nitrogen scavenging by, $\mathrm{S} 2.90$ genetic and virulence variation from wheat and weed Poaceae, S3.5

global efforts in managing, S2.184

hemibiotrophy, S2.186

induction of plant defenses by salicylic acid in perennial ryegrass, $\mathrm{S} 2.117$

interactome of pathogenicity factors, S2.81 mating type genes expression during sexual reproduction, $\mathrm{S} 4.3$

mechanisms of adaptation to host rice cells, $\mathrm{S} 2.43$

potential to infect wheat in the U.S., S3.8

seasonal and daily patterns of conidia availability, $\mathrm{S} 2.81$

spiked-based simulation model for wheat blast incidence, S3.3

TmpL homolog, S4.1

Wscs and Mid2 as putative upstream sensors of cell wall integrity signaling in, S2.167

See also Gray leaf spot; Rice blast

Magnaporthe spp., Pyricularia/Magnaporthe

nomenclature, S2.173

Magnetic capture hybridization real-time PCR,

assay for detecting Agrobacterium vitis, 633

Maguire, I. J., S2.109

Mahaffee, W., S2.93, S2.144

Mahmood, T., S2.88

Main, D., S2.93

Maize. See Corn

Maize ear rot, S2.133

Maize mosaic rhabdovirus (MMV), S2.11

Maize rayado fino virus (MRFV), S2.56

Maize streak disease, modeling control strategies

for, $\mathrm{S} 2.27$

Ma, J., S2.88, S2.116

Majerczak, D. R., S2.171

Malcolm, G. M., 538, S2.68, S2.183

Malinoski, M. K., S2.28

Ma, L. J., S2.34, S2.53

Ma, L.-J., 400

Mallowa, S. O., S2.88

Maltz, M., S2.54

Malus sieversii, blue mold resistant, S2.67

Malvick, D., S2.52, S2.89, S2.123

Malysheva, E., S2.70

Mammella, M. A., 610

Manamgoda, D. S., S2.89

Mandadi, K. K., S2.88

Mandipropamid, S2.95

Manduca, W. L., S2.91

Mang, H. G., S2.19, S2.70

Mango

genetic variability of Ceratocystis fimbriata isolates, S2.107

impact of Ceratocystis fimbriata on seedling growth, S2.137

impact of salinity on Ceratocystis fimbriata wilt, $\mathrm{S} 2.100$

malformation caused by Fusarium

mexicanum, S2.15, S2.136

Pseudomonas syringae pv. syringae differentiated phylotype associated with, 1115

Mangroves

marine lignicolous ascomycetes from, S2.5 saprotrophic oomycete species from a mangrove swamp, S2.153

Manosalva, P., S2.19

Manosalva, P. M., S2.70, S2.89

Mansfield, M. A., 1204, S2.173

Manulis-Sasson, S., S2.24

Manzi, S., S2.124

Maple syrup, fungal production of mycotoxins, S2.8

Marafivirus, S2.87

Marais, A., 293

Maramba, A., S2.108

Marano, A. V., S2.34, S2.68

Marano, M. P., 555

Marçais, B., 190
Mardones, M., S2.52

Marek, L., S2.63

Marek, S., S2.44, S2.99

Marek, S. M., S2.27, S2.108

Marella, H., S2.155

Margaria, P., 776

Marine fungi

ascomycetes, S2.152

lignicolous ascomycetes, S2.5

phylogenetic affiliations, S2.113

Marine, S. C., S2.89

Markell, S., S2.63, S2.91, S2.107, S2.123

Markland, S. M., S2.90

Marois, J. J., S2.40

Marquez, F., S2.90

Marquez-Zequera, I., S3.11, S3.14

Marram grass, S2.69

Marra, R. E., S2.58, S2.90

Marrone, P. G., S2.79, S2.146

Marroquin-Guzman, M. R., S2.90, S2.191

Martínez, F., 870

Martinez, H. Y., S2.9

Martinez, I., S2.55

Martinez-Soto, G., S2.41

Martin, F., 1204, S2.18, S2.33, S2.75

Martin, F. N., 43, 610, S2.91

Martin, G. B., S2.95

Martin, K., S2.61

Martin, M., S3.2

Martin, R., S2.90

Martin, R. R., S2.35, S2.72, S2.90, S2.117

Martín-Sanz, A., 673

Martin, S. B., S2.131

Martins, S. A., S2.91

Martins, S. J., S2.91

Maruthachalam, K., 268, S2.133

Maruwo, J., S2.104

Massimo, N., S2.150

Master, E., S2.180

Masuya, H., S2.96

MAT alleles, in Sclerotinia sclerotiorum, S2.27

Mathew, F., S2.91

Mathioni, S. M., S2.92, S2.143

Matsuda, Y., 623

Matsukura, K., 509

Matsumoto, T. K., S3.14

Matsumura, M., 509

Matthiesen, R., S3.5, S.36

Matthiesen, R. L., S2.92

Mattoo, A., S2.121

Mattox, J. D., S2.86

Mauleon, R., S2.92

Maul, J., S2.60

Mauritia flexuosa, S2.137

Mauzey, S. J., S2.92

Ma, W., S2.188

May, C., S2.119

Mayek, N., S2.91

Mayerhofer, M., S2.92

May, G., S2.34, S2.150, S2.161

Ma, Z., S2.81

Ma, Z. H., S2.80

Mazumder, M., 841

Mazzola, M., S2.60, S2.92, S2.133

Mbofung, G. Y., S2.93, S3.6

McAvoy, E., S2.158

McBeath, J. H., S2.26

McBride, S., S1.7

McCafferty, N., S2.51

McCann, T., S2.93

McClelland, M., 352

McClung, A. M., S2.168

McClure, M., S2.103

McConnell, M. E., S2.191

McCornack, B., S3.6

McCort, C. D., S2.146

McCotter, S. W., S2.93

McCreight, J. D., S3.17

McCullough, B., S1.5 
McDonald, B. A., 862

McDonald, M. R., 245

McElrone, A., S2.13

McFarland, J., S2.182

McGeachy, K., 333

McGhee, G. C., S2.2, S2.79

McGrath, M., S2.56

McGrath, M. T., S2.93

McGregor, L., 245

McGuire, K., S2.30

McIntyre, L., S2.155

McKee, B., 91

McKenna, L. F., S2.121

McLane, H., S2.145

McLaughlin, D. J., S2.93

McManus, P. S., S2.109

McMechan, J., S2.143

McPherson, B., S2.29

McQuate, G. T., S3.14

McRae, A. G., S2.94

McRoberts, N., S2.9, S2.27

McSpadden-Gardener, B., S2.123, S2.141

McTaggart, A., S2.94, S2.150

McTavish, C., S2.155

Medeiros, F. C. L., S2.94

Medeiros, F. H. V., S2.91, S2.94, S2.166

Medeiros, R. B., S2.127

Medel-Ortiz, R., S2.123

Medford, J., S2.148

Medicago truncatula

differing levels of triterpene saponins in response to Phoma medicaginis infection, S2.121

disease progression of Phoma medicaginis on, S1.9

improved biomass and altered transcriptome with colonization by Sebacina vermifera, S2.92

Medina, E. M., S2.185

Meekes, E. T. M., S2.94

Mefenoxam, sensitivity screening service, S2.85

Mehl, H. L., S2.94

Mehl, K., S2.94, S3.6

Mehra, L., S2.95

Meitz-Hopkins, J. C., S2.75, S2.154

Melampsora larici-populina, S2.42

Melampsora larici-puccinia, S2.52

Melampsora rusts, S2.146

Melanson, R. A., S1.7, S2.192

Melcher, U., 129, S2.139, S2.176

Melendez, M. V., S2.89

Melgarejo, T., S2.23

Mellinger, H., S3.13

Mellinger, H. C., S2.158

Meloidogyne chitwoodi, 1092

Meloidogyne enterolobii, 1092

Meloidogyne exigua, 1092

Meloidogyne fallax, 1092

Meloidogyne hapla, 935

Meloidogyne incognita

control with Aspergillus niger-Y61, S2.116

effect of transitional organic production practices on root galling, 792

evaluation of resistance genes in Prunus crops, 833

identifying resistance in soybean cultivars, S2.157

impact of soil composition on, S2.157

management in cucumber with fluensulfone, S1.8

management with tall fescue rotations prior to peach orchard establishment, S2.104 response of African horned cucumber to, S2.144 See also Root-knot nematodes

Meloidogyne mayaguensis, 1092

Meloidogyne minor, 1092

Meloidogyne paranaensis, 1092

Meloidogyne spp., emerging problems with minor species, 1092
Melo, I. S. D., S2.166

Melon (Cucumis melo)

effect of non-Mexican Bacillus subtilis strains on, S2.41

impact of plant age on development of

bacterial wilt, S2.83

induction of antiviral responses against

Cucurbit chlorotic yellows virus, 960

mapping Alternaria cucumerina resistance in, $\mathrm{S} 2.32$

pathogenicity of downy mildew in Costa Rica, S2.16

real-time PCR assay for Fusarium oxysporum in grated genotypes, 802

Melotto, M., 326, S2.105, S2.110, S2.125, S2.185

Melzer, M., S2.111

Membrane-based oligonucleotide array, for the

detection Phytophthora spp., 43

Mena-Ali, J., S2.58

Menalled, F., S2.22, S2.97

Menasha, S. R., S2.93

Mendel, Z., S2.71

Mendoza-Celedón, B., S2.41, S2.112

Mendoza, M. R., S2.105

Mendoza Yerbafria, A., S2.9

Meng, F., S2.95

Mengual, C. M., 1188

Menke, J. R., S2.95

Menkir, A., S1.2

Mentha spp. See Mint

Mentreddy, S. R., S2.105

Mercado, W., S3.13

Merighi, M., S2.171

Mérillon, J.-M., 1028

Mersha, Z., S2.95, S2.111, S3.6

Mertely, J. A., S2.95

Mertely, J. C., S2.95, S2.130

Mesocriconema xenoplax, management on walnut, S2.159

Mesquite pod flour, aflatoxin and, S2.47

Metalaxyl, efficacy in reducing corn seedling blight, S3.5

Methven, A. S., S2.128

Methyl benzamidazole carbamate, sensitivity of

Cercospora kikuchii to, S1.9

Mexican papita viroid (MPVd), S2.80

Meyer, F., S1.10, S2.153

Meyer, S., S2.63, S2.107

Meyers, B. C., S2.36

Meyer, S. L. F., S2.104

Meynard, D., S2.13

Miadlikowska, J., S2.26, S2.149, S2.150, S2.161

micA gene, 1220

Micallef, S. A., S2.89

Micandra spp., S2.134

Michailides, T. J., S2.175, S3.11, S3.12, S3.14, S3.15

Michelin, R., S2.74

Microbial forensics, S2.176

Microbial seed treatments, S2.174

Microbotryum spp., inoculation-based assessment

of infection susceptibility among the

Montiaceae, S2.58

Microcyclus ulei influence of hosts with partial resistance on the genetic structure of, S2.62 population biology, S2.61

Microorganisms, analysis of aerosols collected between 1.5 and $38 \mathrm{~km}, \mathrm{~S} 1.2$

MicroRNAs. See Artificial microRNA-mediated resistance

Mid2, S2.167

miD05 gene, 175

Miettinen, O., S2.96, S2.108

Mihail, J., S2.96

Miles, C. A., S3.15

Miles, L. A., S2.96

Miles, T. D., S2.96, S2.127, S2.161
Miller, A. N., S2.64, S2.97, S2.119, S2.172

Miller-Butler, M. A., S2.97

Miller, G. L., S2.30

Miller, R. N. G., S2.137

Miller, S., S2.12

Miller, S. A., S2.13, S2.26, S2.184

Miller, S. J., S2.96

Miller, S. L., S2.36

Miller, Z., S2.22, S2.97

Milling, A., S2.32, S2.66, S2.86

Milner, H., S2.162

Milus, E. A., S2.97

Mimee, B., S2.124, S2.147

Miñarro, M., S2.12

Minato, N., S2.123

Minenkova, O., S2.165

Ming, R., S2.166

Minnis, A. M., S2.70

Minsavage, J., S2.131

Mint (Mentha spp.), genetic structure of

Verticillium dahliae populations, 445

Minz, D., 23

Miorini, T. J., S2.138

Mirtalebi, M., S2.97

Miscanthus $\times$ giganteus. See Giant miscanthus

Mishra, D., S2.152

misL gene, 362

MisL protein, 362

Misner, I., S2.98, S2.121

Mitchell, A. J., S3.6

Mitchell, T. R., S2.16

Mitchum, M. G., S2.129

Mitochondrial DNA sequences, genetic variation in isolates of Phytophthora nicotianae, 610

Mitochondrial DNases, fungal mitochondrial

DNases and the activation of nonhost resistance, 81

Mitochondrial genes, RNA editing in Didymium iridis, $\mathrm{S} 2.90$

Mitra, R. M., S2.66, S2.86

Mittal, S., S2.142

Miwa, T., 733

Mixia osmundae, S2.146

Mizubuti, E., S2.126

Mizubuti, E. S. G., S2.61, S2.62

Mlotshwa, S., S2.187

Mmbaga, M., S2.98

Mochiah, M. B., S2.12

Mohamed Nor, N. M. I., S2.98

Mohammadi, M., S2.21, S2.138

Mohotti, K., S2.71

Molan, Y. Y., S2.39, S2.125

Molds

isolated from New Jersey residential buildings following Superstorm Sandy, S2.99

sooty mold, S2.19

See also Blue mold; Grain mold; Gray mold

Moleleki, L. N., 1268

Moleleki, N., 1268

Molina, O. I., S2.98

Molineros, J. E., 906

Molliculites. See Spiroplasma kunkelii

Molnár, K., S2.26

Molnar, T. J., S2.100

Monacell, J., S2.150

Monacell, J. T., S1.8, S2.161

Moncada-Monsivais, D., S2.60, S2.186

Monchiero, M., 64

Moncrief, I., S2.99

Monfort, W. S., S1.10, S2.137

Monilinia fructicola Collimonas sp. ZLZ261 and, S2.84 fungicide-induced mutagenesis, S2.128 multi-drug resistance to site-specific fungicides, S2.55

Monilinia vaccinii-corymbosi, S2.21

Moniliophthora roreri, S2.35

Monique, G., S2.124

Monogalactosyldiacylglycerol (MGDG), 74 
Monopartite begomoviruses association with okra leaf curl disease, S2.5 infection of Sida spp., S2.23

Monosporascus cannonballus, S2.138

Monroy-Barbosa, A., 472

Montero-Astúa, M., S3.7

Montes-Borrego, M., 1058

Montiaceae, inoculation-based assessment of infection susceptibility to anther smut disease, $\mathrm{S} 2.58$

Monyo, E., S2.104

Moon, D. E., S2.97

Moore, G., S2.132

Moore, M. J., S2.108

Mora-Aguilera, J. A., S2.39

Morales-Santos, F. J., S2.99

Moran-Diez, M. E., S2.99

Morán, M., S2.123

Morath, S. U., S2.99

Morchella spp., S2.96

Moreau, P. A., S2.124

Moreira, S. I., S2.143, S4.3

Morels, S2.96

Moreno, A., 1188

Moreno, P., 1077

Moretti, A., S2.175

Morey, K., S2.148

Morgan, D. P., S2.175, S3.11, S3.14, S3.15

Mori, R., 575

Morisette-Thomas, V., 811, 1087

Moroccan pepper virus (MPV), 501, S2.160

Morrice, J., S2.52

Morris, K. A., S1.8

Morse, A., S2.155

Mortierella elongata, co-evolution with

endosymbiotic bacteria, S2.18

Mosier, N., S2.35

Mosquera, G., S2.19, S2.186

Mosquitoes, trichomycete fungi and, S2.13

Mou, B., 268

Mouriño-Pérez, R., S2.34, S2.118, S2.187

Moustaid-Moussa, N., S2.109

Mou, Z., S2.134

Movement proteins, 513

Mowery, P., S2.69

Mo, W. L., S2.170

Mo, X., S2.98

Moya-Elizondo, E. A., S2.100

Mucci, C. W., S2.163

Mucor, new species from Brazil, S2.34

Muehlbauer, M. F., S2.100

Mueller, D., S2.56

Mueller, G., S2.58

Mueller, O., S2.185

Mukanga, M., S2.70

Mukhina, Z., S2.15

Mulè, G., S2.175

Mullens, B., S2.53

Mullis, M., S2.63

Multilocus ISSR markers, 182

Multilocus sequence typing (MLSST), 673

Multiplex one-step RT-PCR

detection of nepoviruses infecting imported germplasm, S2.113

detection sweet potato potyviruses, S2.109

Multiplex PCR

detection and identification of Ralstonia solanacearum, S2.140

end-point multiplex PCR identification of plant viruses, S2.9

identification of high consequence Bemisia tabaci biotypes and Trialeurodes vaporariorum, $\mathrm{S} 2.7$

Mummy berry disease, Internet-served forecast systems, S2.8

Mundt, C., S2.41

Mungbean, fluorescent Pseudomonas associated

with the mycorrhizosphere of, S2.18

Munkvold, G., S2.21, S2.175
Munkvold, G. P., 822, S2.7, S2.31, S2.39, S2.40, S2.134, S2.153

Munoz Bodnar, A., S2.67

Munyaneza, J., S2.104, S2.130

Murillo, J., 673, 1115

Murine norovirus (MNV), 389

Murolo, S., 785

Murphy, A. F., S2.38

Murphy, C. A., S2.18

Murphy, J. F., S2.100

Murphy, K. M., S2.3

Murray, T. D., 98, S2.92

Murta, H. M., S2.100, S2.137

Musa, susceptibility to banana bunchy top disease, S2.103

Muscadine grape, effects of fungicide applications on, S2.135

Musca domestica (house fly), 373, S2.185

Muscodor albus SA-13, S2.79

Mushinski, R., S2.19

Muskmelon, impact of plant age on development

of bacterial wilt, S2.83

Musser, R., S2.115, S2.149

Mustful, M., S2.86

Musungu, B., S2.101

Mutschler, M. A., S2.101

Muyldermans, S., S2.188

Mycelial compatibility groups (MCGs) genetic diversity in Sclerotinia sclerotiorum, 750

identifying in Sclerotium rolfsii, 479

Myclobutanil resistance, in Venturia inaequalis isolates, S2.153

Mycodiplosis, S2.102

Mycoheterotrophy, S2.64

Mycological Society of America, Student Section, $\mathrm{S} 2.54$

Mycology

evolutionary informatics, S2.177

identification of Berberis spp. as alternate hosts of Puccinia striiformis f. sp. tritici, 927 identifying mycelial compatibility groupings in Sclerotium rolfsii, 479

Mycorrhizal fungi

large-scale genomic and transcriptomic analysis, S2.75

response to fire, $\mathrm{S} 2.183$

See also Arbuscular mycorrhizal fungi; Ectomycorrhizal fungi

Mycosphaerella graminicola

calculating fungicide dose decisions on winter wheat, 666

cell-based high-throughput assay for responses to fungicides, $\mathrm{S} 2.51$

fungicide application timings for disease control are an effective anti-resistance strategy, 1209

fungicide strategies in resistance management on winter wheat, 690

Mycotoxins

emerging issues in food safety, S2.175

produced by fungi in maple syrup, $\mathrm{S} 2.8$

produced by rice false smut pathogen, $\mathrm{S} 2.184$

Myers, K., S2.33

Myers, M. E., S2.52

Myrold, D., S2.182

Myrtaceae, new Ophiodothella species on, S2.127

Mysore-Venkatarau, S., S2.47

Myxomycetes, on Orbygnia sp., S2.3

Naegele, R. P., S2.101

Nagabhyru, P., S2.101

Nagl, N., S2.21

Nagy, L. G., S2.101, S2.142, S2.181

Nagyová, A., 972

Nagy, Z. Á., 190

Naidu, R. A., S2.114

Nakajima, M., 513
Nakasone, K. K., S2.85

Nakazono-Nagaoka, E., 513

Nakhla, M. K., 488, S2.20, S2.30, S2.109, S2.113, S2.124, S2.179

Namba, S., S2.123

Nanoscale titanium dioxide formulations, 228

Napieralski, S., S2.123

Nara, K., S2.58

Narrow brown leaf spot

efficacy of Bacillus in biocontrol with organic rice, $\mathrm{S} 2.168$

See also Cercospora janseana

Nash, T., S2.97

Natarajan, B., S2.59

National Biosurveillance Integration Center

(NBIC), S2.176

National Clean Plant Network, S2.179

National Plant Diagnostic Network (NPDN), S2.177

Naturalis, 1001

Natvig, D. O., S2.64, S2.115

Navarrete, F., S2.102

Navarro, L., 1077

Navarro-Leon, M. J., S2.112

Navas-Cortés, J. A., 479, 1058

Naveed, K., S2.110

Navia Gine, P. A., S1.8

NB-LRR genes, S2.46

Nectarine, leaf abscission and infection by

Xanthomonas arboricola pv. pruni, S2.173

Nectar microfungi, S2.181

Neher, O. T., S2.21, S2.102

Neibling, H., S2.102

Nelsen, D. J., S2.102

Nelson, B., S2.27

Nelson, B. D., S2.21, S2.117, S2.123, S2.164

Nelson, L., S2.121

Nelson, L. D., S1.9

Nelson, R., S2.7, S2.122

Nelson, R. J., S4.3

Nelson, R. S., S2.188, S2.189

Nelson, W., S2.44

Nematicides

plant viral nanoparticles to increase mobility and stability, S2.85

silver nanoparticles in turfgrass, $\mathrm{S} 1.2$

Nematode-protectant seed treatments, S2.174

Nematology

MiD05 parasitism gene of root-knot nematodes, 175

segregation and mapping of quantitatively inherited traits affecting parasitism in Meloidogyne hapla, 935

Neofusicoccum parvum black spots on avocado in Mexico, S3.12 See also Botryosphaeria dieback

Neonectria coccinea, S2.126

Neonectria ditissima, S2.23

Neonectria faginata, S2.23, S2.126

Neonectria microconidia, S2.126

Neonectria punicea, S2.126

Neo-nicotinoid insecticides, in control of citrus canker, S2.52

Neotyphodium coenophialum alteration of ergot alkaloid profile through chromosome end knockoff, S2.44 effect on tall fescue under drought stress, S2.101

Neotyphodium spp., S2.133, S2.185

Nepal, A., S3.7

Nephelium lappaceum, S2.130

Nepoviruses

detection with a multiplex one-step RT-PCR, $\mathrm{S} 2.113$

molecular characterization of a novel soybeaninfecting nepovirus, S2.164

Neri, F. M., 1012

Nester, S. E., 708, S2.18

Nettleton, D. S., S2.171 
Neurospora crassa

cell wall changes in an endocytosis mutant, S2.118

communication modules, S2.186

GFP-immunoelectron microscopy of endocytic vesicles, S2.34

growth and secretory vesicles, S2.186 septum formation and cytokinesis, S2.187

Newell, A. D., 1045

'New Mexico Capsicum Accession 10399', 472

Newsom, L. J., S1.1

Next generation sequencing

application to biosecurity, S2.33

characterization of tree fruit and grapevine viruses, S2.124

comparative analysis of Fusarium graminearum, $\mathrm{S} 2.134$

development of diagnostic tools for seed borne pathogens, S2.140

diagnostics of shotgun poplar disease, S2.35

Ngatat, S., S2.65, S2.103

Ngugi, H., S2.55, S2.173

Nguyen, H., S2.76

Nguyen, H. D. T., S2.103

Nguyen, M. H. R., S2.152

Nguyen, N., S2.70

Nguyen, T. L., S2.163

Niazi, N. S., S2.147

Nicandra physaloides, 436

Nickerson, N. L., S2.103

'Nicky Crisp' Camellia, 725

Nicolau, M., S3.3

Nicotiana benthamiana

association of Cauliflower mosaic virus P6 inclusion bodies with plasmodesmata, S2.122

targeting of AGO2 compromises antiviral silencing of a tombusvirus, S2.105 vaccination with a lab-attenuated strain of Pepino mosaic virus, S2.26

Nicotiana spp., coat protein of Tobacco necrosis virus elicits hypersensitive response, S2.43

Nicot, P. C., 261

Nieblas-Núñez, N., S2.103

Niemelä, T., S2.96

Nierman, W. C., S2.144

Nikolaeva, E., 1204, S2.74

Nils, B., S2.9

Niño-Mendoza, G. H., S2.112

'Nipponbare' rice variety, 594

Nischwitz, C., S2.72, S2.103, S2.107

Nissen, L. D., S1.8

Nitric oxide detoxification, of Fusarium

verticillioides, S2.11

Nitric oxide reductase, $\mathrm{S} 2.32$

Nitrogen fertilization effect of host nitrogen nutrition on Botrytis cinerea secondary inoculum, 261 effect on Wheat streak mosaic disease, S2.97

Nitrogen pollution, plant-microbe relationships, S2.60

Niu, C., S2.104

Njoroge, S., S2.104

Nocchi, P. T. R., S2.50

Noël, L. D., S2.170

Nogueira Júnior, A. F., S2.104

Noh, J., S2.71

Noling, J., S2.130

Nonhost resistance

of Arabidopsis thaliana against Alternaria alternata, 733

fungal mitochondrial DNases and the activation of, 81

Non-native phytoalexins, potential use in

controlling soybean pathogens, S3.7

Nonomura, T., 623

Nontyphoidal Salmonella, 316

Nopsa, J. H., S2.145

'Norin4' wheat cultivar, 575
Norli, H. R., S2.43

Norman, D., S2.4

Norman, D. J., 237, S2.17, S2.18, S2.73

Noroviruses, survival on spinach during preharvest growth, 389

Norovirus surrogates, survival on spinach during preharvest growth, 389

North American Plant Protection Organization (NAPPO), S2.78

Northern Leaf Blight of maize, 641

Noussourou, M., S2.23

Nowogrodzki, A., S2.22

NPRl gene, S2.134

$n t p R$ gene, S1.7, S2.192

Nuclear DNA sequences, genetic variation in

isolates of Phytophthora nicotianae, 610

Nucleocapsid proteins, 513

Nucleotide-binding site (NBS) domains,

resistance gene homologues in common bean, 156

Nucleotide-binding-site leucine-rich repeat (NBS-

LRR) proteins, 594

Nuhn, M., S2.104

Nunes, W. M. C., S2.50

Nunez-Palenius, H. G., S2.41, S2.112

Nusayr, T., S2.31

Nut crops

Botryosphaeriaceae among temperate nut crops in California, S3.14

See also specific nut crops

Nutter, F., S2.176

Nutter, F. W., S2.35, S2.51

Nwosu, V., S2.183

Nwugo, C., S2.104

Nyczepir, A. P., S2.104

Nyochembeng, L. M., S2.105

Oats, yield losses due to crown rust, S2.19

Oberhofer, M., S2.105, S2.165

Obligately lichen-associated fungi, S2.186

Obulareddy, N., S2.105

Ocamb, C., S2.38

Ochoa-Corona, F. M., S2.7, S2.8, S2.9, S2.33, S2.176

Ochoa, J. B., S2.191

Odokonyero, D., S2.105

Odom, J. L., S3.7

O’Donnell, K., S2.71, S2.114, S2.172

Ofek, M., 23

Ogamino, T., 513

Ogunbayo, T., S2.105

Ohm, R., S2.18, S2.106

Ojiambo, P., 216, S2.79, S2.95, S2.106, S2.145

O'Keeffe, T. L., S2.175

Okra leaf curl disease, S2.5

Okuda, M., 509, 960

Okuda, S., 960

Olalde-Portugal, V., S2.41

Olarte, R. A., S1.8, S2.106

Olaya, G., S2.106

O'Leary, M. L., S2.106

Oligonucleotide arrays, detection Phytophthora spp., 43

Oliva, R., S2.35

Olivares-Mercado, P. X., S2.134

Olive (Olea europaea), monitoring of asymptomatic infections by Verticillium dahliae, 1058

Oliveira, L. S., S2.107

Oliveira, M. S., S2.107

Oliver, A. K., S2.107

Oliver, J. E., S2.107

Oliveros, O. A., 156

Oliver, R. P., 690

Olpidium bornovanus, S2.138

Olsen, M., S2.27, S2.103, S2.107

Olson, J., S2.9

Olson, L. K., S2.107

Olson, S. M., 228
Omura, T., 513

O'Neill, E., S2.12

1000 Fungal Genomes Project, S2.137

Ong, K., S2.49, S2.177

Onion

DNA microarray detection of bulb rot, S2.8 environmental and management factors associated with bacterial rots, S2.173

Onion bulb rot, $\mathrm{S} 2.8$

Onion stunting, management, S2.131

Onion thrips (Thrips tabaci), S2.142

Oni, R. A., S2.89

Online courses and programs, S2.189

Onuki, M., 509

Oomycetes

associated with soybean seedling diseases, $\mathrm{S} 2.123$

chitin synthase gene, S2.108

environmental metagenomics, S2.178

isolated from soybeans with damping-off, $\mathrm{S} 2.25$

measuring biodiversity, S2.178

saprotrophic species from a mangrove swamp, S2.153

similarities with true fungi, 1035

Open Tree of Life Project, S2.48

Ophiodothella, S2.127

Ophiodothella vaccinii, S2.56

Ophiognomonia clavigignenti-juglandacearum, S2.66

Ophiosphaerella herpotricha

impact of nitrogen source and $\mathrm{pH}$ on mycelial growth, S2.30

phylogenetic placement, S2.44

Ophiosphaerella korrae

impact of nitrogen source and $\mathrm{pH}$ on mycelial growth, S2.30

phylogenetic placement, S2.44

Ophiosphaerella narmari, S2.44

Opperman, C. H., S2.85

Orange rust, introduction into the Louisiana

sugarcane industry, S2.53

Orbygnia sp., S2.3

Orce, I. G., 555

Ordoñez, M. E., S2.11, S2.12, S2.108

Oreomunnea mexicana, S2.30

Organic agrofungicides, S2.72

Organic fertilization, response of soil microbial communities to, S3.4

Organic potatoes, variety and production trials, S2.25

Organic production practices, effect on tomato soilborne pests, 792

Organic rice, efficacy of Bacillus as biocontrol agents for sheath blight and narrow brown leaf spot, S2.168

Organic tomatoes, fungal and oomycete pathogen detection, S2.141

Ornella, L., 555

Orquera, G., S2.108

Orshinsky, A., S2.14, S4.1

Ortega-Arreola, R., S2.15

Ortega-Beltran, A., S2.108, S2.175

Ortiz-Santana, B., S2.108

Oryza rufipogon. See Wild rice

Oryza sativa. See Rice

Osei, M. K., S2.12

Oshea, P., S2.158

Ospina-Giraldo, M., S2.74, S2.108

Osti, S., S1.8

Ostry, M., S2.66, S2.108

Osuna Avila, P., S2.136

Otero-Colina, G., S2.124

Otten, W., 1012

Otto-Hanson, L. K., 34, S3.5

Otto, K., S3.17

Oudemans, P. V., S2.109, S2.112, S2.114

Outwater, C. A., S2.191

Owensby, C. A., S2.109 
Owens, K. J., S2.109, S2.113

Ownley, B. H., S2.84, S2.109

Oxalate decarboxylase gene, S2.81

Oxalis corymbosa. See Gold Veined Oxalis

Oxathiapiprolin, S2.111

Oxidized lipids, control of Aspergillus disease

development in maize, S2.19

Oxytetracycline resistance, in Xanthomonas

arboricola pv. pruni, S2.11

Ozias-Atkins, P., S1.9, S2.183

Pace, R., S2.185

Pachyphlodes-Scabropezia lineage, S2.58

Padgett, G. B., S1.9, S2.116

Padhi, S., S2.99

Paecilomyces lilacinus YES-2-14, S2.83

Paetzold, L., 1235, S2.162

Paéz, C. P., S2.58

Pagadala, S., S2.89

Pagliaccia, D., 91, S2.107

Pahl, D. M., S2.89

Pain, A., S2.98

Pakala, S., S2.144

'Palisades' zoysiagrass, S1.8

Palma-Guerrero, J., S2.186

Palmano, S., 776

Palmateer, A. J., S2.109

Palmer, C. L., S2.18, S2.151

Palm, M. E., S2.172

Palm trees

diseases in Central America, S2.177

invasive threats to, $\mathrm{S} 2.177$

phytoplasmas, S2.177

Palumbo, J. D., S2.175

Panaccione, D. G., S2.44, S4.3

Panchal, S., 326, S2.110, S2.125

Pandey, R., S2.98

Pang, Z., 594, 920

Panicum, S2.183

Panicum mosaic virus (PMV), S2.88, S2.138

Panicum virgatum. See Switchgrass

Panijel, M., S2.24

Pan, J., S2.109, S2.165

Pankratova, L., S2.15

Panthee, D., S2.134

Pantoea agglomerans

development of a bioreporter, S2.84

environmental and management factors, $\mathrm{S} 2.173$

Pantoea agglomerans pv. gypsophilae, S2.24

Pantoea ananatis, S2.173

Pantoea stewartii, type III secretion system in

vector transmission, $\mathrm{S} 2.171$

Pantoea stewartii subsp. stewartii

sideophore-mediated iron uptake for in plant growth, S2.21

trend study in the U.S., 2001-2012, S3.3

See also Stewart's wilt of corn

Paolinelli-Alfonso, M., S2.110

Papaya (Carica papaya)

anthracnose caused by Colletotrichum spp., S3.11

evolutionary history and genetic diversity of

Phoma caricae-papayae, S2.178

genetic structure of Colletotrichum

gloeosporioides sensu lato isolates from, 182

pathogenicity of Pythium aphanidermatum, S3.14

Papaya ringspot virus-W (PRSV-W), S2.1

Papp, T., S2.142

Pappu, H., S2.110, S2.130, S2.148, S3.12

Paranectria, S2.59

Parasitism genes, 175

Paratritirachium, S2.103

Pare, P. W., S2.94

Paret, M. L., 228

Parikh, L., S2.98

Park, B., 1204

Parke, J., S2.77
Parke, J. L., S2.46

Parker, M., S2.111

Park, J.-H., 565

Park, J. K., S3.7

Park, S., S2.141, S3.7

Park, S.-Y., 1204

Parkunan, V., S2.162

Parque Estadual da Ilha do Cardoso (PEIC), S2.68

Parque Estadual digestive-absorptive systems

Fontes do Ipiranga (PEFI), S2.68

Parra, C. C., S2.75, S2.86

Parris, K., S2.37

Pasche, J. S., S2.111, S3.4, S3.7

Passalid beetles, S2.150

Pastor-Corrales, M. A., S2.132

Patel, H. K., S2.118

Patel, J. S., S2.98, S2.111

Patel, N., S2.112

Pathogenesis related genes, expression profiling and evolution in maize in response to Ustilago maydis, $\mathrm{S} 2.25$

Pathogenic symbioses, compared to lichen symbioses, S2.185

Paula, P. V. A., S2.151

Paulitz, T., S2.131

Paulitz, T. C., 1130, S2.3

Paul, P., S2.33

Paul, P. A., 906, S2.7, S2.88, S2.123, S2.127,

S2.131, S2.173

Pavan, W., S3.3

Paveley, N. D., 666, 690, 1209

Pawlowski, M. L., S3.7

Payne, A., S2.112

Payne, G., S2.104

Payne, G. A., S2.79, S2.133

Payton, P., S2.94

Pazdernik, K., S2.51

pC6 movement protein, 513

pC5 nucleocapsid protein, 513

PCR-RFLP

analysis of the Fusarium oxysporum species complex isolated from soybean, S2.40 assay for genetic diversity studies of Elsinö̈ australis, S2.30

Pea (Pisum sativum)

genetic and phylogenic diversity of Pseudomonas syringae pv. syringae strains from, 673

measuring root disease suppression in response to a compost water extract, 255

Pea bacterial blight, 673

Peach (Prunus persica)

bacteriophage ecological niches and coevolution with Xanthomonas arboricola pv. pruni, S2.135

characterization of Armillaria root disease in Mexico, S2.39

leaf abscission and infection by Xanthomonas arboricola pv. pruni, S2.173

Peach rosette mosaic virus (PRMV), S2.49

Peanut (Arachis hypogaea)

effect of crop rotation on diseases, nematode activity, and yield, S2.23

effect of planting date and early season prothiconazole applications on stem rot, S2.149

effect of temperature on Sclerotium rolfsii growth, S1.10

evaluation of flutriafol for diseases, S1.11 mini core collection at ICRISAT, S2.141

molecular diversity of peanut rust pathogen and its host, S1.9

monitoring leaf spot diseases, S1.8

Rhizoctonia solani AG-1 1A infection in

Arkansas, S2.42

seed treatments in disease management in

Nicaragua, S3.12

See also Groundnut; Valencia peanut
Peanut Genome Consortium, S2.183

Peanut Genome Initiative (PGI), S2.183

Peanut Genome Project (PGP), S2.183

Peanut rust

molecular diversity of pathogen and its host, S1.9

See also Puccinia arachidis

Peanut stem rot, S2.149

Peay, K. G., S2.41, S2.82, S2.181, S2.182

Pecan, fungicide spray coverage from ground-

based sprayers, S2.17

Pecan scab

fungicide spray coverage from ground-based sprayers, S2.17

trunk application of phosphite for control of, S2.17

Pecan truffle (Tuber lyonii), S1.2, S2.135

Pectobacterium carotovora, S2.173

Pectobacterium carotovorum subsp. brasiliense, 1268

Pedley, K. F., 1169

Peever, T. L., 445, 741, S2.123

Pegues, M., S2.54

Pelargonium, bacterial blight in, S2.94

Pelletier, D., S2.18

Pelletier, G., S2.76

Peltigera canina, S2.149

Peltzer, D., S2.182

Peng, G., 245

Pengue, G., S2.155

Peng, Y., S2.184

Penicillium digitatum, genotyping imazalil resistance in, $\mathrm{S} 2.72$

Penicillium expansum, stability and

pyrimenthanil-resistant phenotypes from apple, S2.22

Penicillium spp.

host range of rotting bulb crops, S2.37

multilocus database for identification, S2.113

Pepino mosaic virus, S2.26

Pepper

attachment and germination Phytophthora

capsici of zoospores on roots, S2.37

detection and quantification of Leveillula

taurica growth in leaves, 623

internode stunting from Cucumber mosaic virus, S2.100

molecular diagnosis of bacterial spot pathogens, S2.74

population structure of Phytophthora capsici in China, 920

See also Capsicum annuum

Peralta, E. L., S2.117

Perazzolli, M., 1227

Percival, G., S2.67

Percolation-based risk index, for pathogen invasion, 1012

Peregrinus maidis, S2.11

Pereira, A., S2.30

Pereira-Carvalho, R. C., S2.112, S2.137

Pereira, F. B., S2.166

Pereira, R. B., S2.6

Perennial ryegrass (Lolium perenne)

induction of plant defenses by salicylic acid against gray leaf spot, S2.117

molecular and genetic basis of mutualism with Epichlö̈ festucae, S2.13

spatial patterns of ergot in seed fields, S2.37

Peres, N. A., S2.14, S2.45, S2.51, S2.90, S2.95,

S2.107, S2.112, S2.130, S2.134

Perez, C. A., S2.123

Pérez de la Vega, M., 673

Perez Garcia, M., S2.8, S2.9

Perez-Hernandez, O., S2.83, S3.7

Perez-Moreno, L., S2.41, S2.112

Pérez-Serrano, V., 1058

Pérez-Sierra, A., 851

Perina, F. J., S2.6, S4.3

Perkins, L. B., S2.8 
Peronosclerospora, $\mathrm{S} 2.179$

Peronosclerospora sorghi, $\mathrm{S} 1.7$

Peronospora belbahrii, S3.6

See also Basil downy mildew

Peronospora farinosa f. sp. spinaciae, $\mathrm{S} 2.42$

Peronospora variabilis, S2.191

Perring, T., S2.119

Perry, B., S2.47

Perry, K. L., S2.145

Persea americana. See Avocado

Pertot, I., 1227

Perumal, R., S2.11, S3.2

Pesce, C., S2.170

Pesic-VanEsbroeck, Z., S2.5

Pesticide Risk Mitigation Engine (PRiME), S2.29

Peter, K. A., S2.67, S2.70

Petersen, R., S2.113

Petersen, R. H., S2.62, S2.63

Peterson, G., S3.8

Peterson, G. L., S2.178

Peterson, S., S2.113

Petri disease. See Phaemoniella chlamydospora

Pew, T., 255, S3.16

Peziaceae, S2.58

Pezizomycotina, S2.130

Pfeiffer, D. G., S2.189

Pfenning, L. H., S2.113, S2.122, S2.136

Pfeufer, E. E., S2.173

Pfister, D. H., S2.54

Phacidiopycnis washingtonensis, S2.133

Phaemoniella chlamydospora

explaining grapevine defense response to, 1028 genetic diversity in North American populations, $\mathrm{S} 2.148$

Phage therapy

for horse chestnut bleeding canker, S2.67 See also Bacteriophage

Phakospora pachyrhizi

Arabidopsis nonhost resistance genes to defeat, S2.77

effects of frequency of "extreme" temperature highs on, 708

effects of mineral nutrition on, S2.133

efficacy of disinfestants in killing urediniospores of, $\mathrm{S} 3.2$

VIGS study of proteins in interactions with soybean, $\mathrm{S} 1.4$

See also Soybean rust

Phanerochaete carnosa, S2.180

Phaseolinone, S2.101

Phaseolus lunatus. See Lima bean

Phaseolus vulgaris. See Common bean

Phaseolus vulgaris endornavirus 1, S2.73

Phaseolus vulgaris endornavirus 2, S2.73

Phellinus noxius, $\mathrm{S} 2.28$

Phellinus sensus stricto, $\mathrm{S} 2.20$

Phellinus sulphurascens, 583

Phenazine, 995, S2.155, S2.164, S2.165

Phenazine-producing Pseudomonas spp., determination in wheat, $\mathbf{S} 2.100$

Phenolic biomarkers, S2.29

Phenylalannine ammonia lyase 4 gene, S2.89

Phialocephala fortinii, S2.149

Phillips, T. W., S2.59, S3.4

Phillospheric yeasts, S2.85

Phloem sieve elements, visualization of

'Candidatus Liberibacter asiaticus' cells in citrus seed coats, 545

Phlox (Phlox paniculata), susceptibility to

Phytophthora nicotianae, S2.36

PhoA assay, S2.157

Phoenix dactylifera. See Date palm

Phoma caricae-papayae, S2.178

Phoma macrostoma var. macrostoma, $\mathrm{S} 4.1$

Phoma medicaginis

complementing T-DNA replaces original

T-DNA in tagged mutants, S2.27

response to Medicago truncatula saponins, S1.9, S2.121
Phoma pinodella, 255

Phomopsis gulyae, $\mathrm{S} 2.91$

Phomopsis helianthi, S2.91

Phomopsis seed decay, evaluating soybean for resistance, $\mathrm{S} 2.80$

Phomopsis spp., pathogenicity on soybeans from

Minnesota, S2.89

Phompsis stem canker, characterizing

aggressiveness in sunflower, S2.91

PhoP/Q regulatory system, of Xylella fastidiosa, S2.191

Phormia regina, $\mathrm{S} 2.185$

Phosphite fungicide

foliar application in control of apple scab, S2.39

trunk application for control of pecan scab, S2.17

Phosphonate, pre- and postharvest management of citrus brown rot, $\mathrm{S} 2.3$

Phosphorous acid, control of bacterial diseases and PR-gene induction, S2.79

Photocatalysis, 228

Phylloplane yeasts. See Ballistosporic phylloplane yeast survey

Phymatotrichopsis omnivora control in grapevines, S1.7 investigating the genetic structure of, S2.27

Physalis peruviana (Cape gooseberry), S2.14

Physalospora vaccinii, S2.109

Phytophthora alni subsp. alni, 190

Phytophthora alni subsp. uniformis, 190

Phytophthora blight

effect of Chlorella on sporangia production, S3.16

managing with biofumigation, S2.93

on squash, biocontrol with Bacillus subtilis IN937b, S2.98

Phytophthora capsici

attachment and germination of zoospores on pepper roots, $\mathrm{S} 2.37$

biocontrol with Bacillus subtilis IN937b, S2.98

effect of Chlorella on sporangia production, S3.16

induced resistance by eicosapolyenoic fatty acids in tomato, S2.122

management in watermelon, S1.6

management with biofumigation, S2.93

novel Capsicum gene inhibiting host-specific resistance to, 472

population structure in pepper from China, 920

QTL mapping of resistance in Capsicum annuит, $\mathrm{S} 2.101$

Phytophthora cinnamomi

characterization in ornamental crops in South

Carolina, S2.128

mitochondrial haplotype and nuclear genotype correlation, S2.91

population genetic structure of, 91

use of fungal "cocktail" to inhibit growth, S2.160

white oak decline and, S2.19

Phytophthora citricola, 1020

Phytophthora Database 2.0, 1204

Phytophthora fruit rot

resistance in Capsicum, S2.101

of watermelon, management, S1.6

Phytophthora infestans

efficacy of copper hydroxide in inhibiting growth of, S3.6

Halliwell-Asada pathway in photosynthesis shutdown in the compatible interaction with potato, S2.23

investigation of populations in and near central New York, S2.33

morphological variation of Thai isolates from potato, $\mathrm{S} 2.26$

novel clonal lineages elicit differential disease and pathogen responses, S2.49 pathogenicity and host range from potato in

Thailand, S2.136

population dynamics in Egypt, S2.39

Phytophthora infestans resistance

development of diploid potato breeding lines with, S2.49

in heirloom and hybrid tomatoes, S2.129

Phytophthora-infested water, plant health risks

from irrigation with, $\mathrm{S} 1.7$

Phytophthora multivora, 1020

Phytophthora nicotianae

analyses of genetic variation inferred from mitochondrial and nuclear DNA sequences, 610

biological control by heat-tolerant bacteria in irrigation water, S2.56

in Florida citrus groves, S2.36

susceptibility of phlox to, S2.36

Phytophthora parasitica

detection and molecular identification from annual vinca in Nevada, S2.155

Ppmid1 gene in asexual development, S2.64

Phytophthora pini, 1020

Phytophthora plurivora, 1020

Phytophthora ramorum

comparative genomic analysis, S2.82

concentration of sporangia or zoospores for infection of host roots, $\mathrm{S} 2.132$

detection by sampling water in retention ponds, S2.136

disinfesting runoff water contaminated with, S2.77

genome-wide patterns of diversity, S2.32

interaction with root stress and chemical

management in potted rhododendron, S2.124

phenolic biomarkers for prediction in coast

live oak, S2.29

population dynamics in a California forest, 1141

steaming to eradicate from nursery soil, S2.129

update on clonal populations in the U.S., $\mathrm{S} 2.41$

Phytophthora root rot of avocado, 91

Phytophthora rubi, S2.139

Phytophthora sojae

genetic changes underlying pathotype shift in, S3.1

glyceollin in soybean plant defense against, 984 polysaccharide lyase genes and the infection of soybeans, S2.74

production of RNA-silencing repressors, $\mathrm{S} 2.188$

Phytophthora spp.

biocontrol agents to control in chile pepper, S2.56

effects of solarization and biocontrol in container nurseries, S2.46

expanding host range of a Phytophthora hybrid, S2.79

functional analysis of the host target of an RXLR effector, S2.4

genomics-based diagnostic marker development for, S2.65

isolation from stream ecosystems, S4.2

membrane-based oligonucleotide array for the detection of, 43

migration and evolution, S2.177

plant health risks from irrigation with

Phytophthora-infested water, S1.7

polymorphic microsatellite markers, 1020

production of RNA-silencing repressors to promote infection, $\mathrm{S} 2.188$

three novel species from irrigation water in Mississippi, S2.164

Phytoplasma NAGYIII, S4.1

Phytoplasmas

field treatment of grapevine bois noir with resistance inducers, 785 
hydrogen peroxide accumulation and transcriptional changes in grapevines recovered from Flavescene dorée disease, 776

infection of native and introduced trees in Colombia, S2.46

molecular characterization of lethal yellows, S2.177

palm phytoplasma detection, S2.177

16SrXII-E group, S2.26

strains associated with diseased potatoes in

China, S2.26

Pianosi, A., S2.52

Piatek, M., S3.13

Picard, K. T., S2.113

Picton, D. D., 488, S2.109, S2.113

Pid3-A4 resistance gene, 594

Pid3 resistance gene, 594

Pierce, B., S2.191

Pierce, N. E., S2.16

Pierce's disease

effects of rootstock on infection and grapevine sap phenolics, S2.154

in grafted grape cultivars, S2.126

phoP/Q two-component system, S2.19

therapeutic and prophylactic application of phage, S2.34

Pierson, E. A., S2.79, S2.155, S2.164, S2.165

Pierson, L. S., S2.155, S2.164, S2.165

Pierson, T., S1.3

$P i$ - $h k l$ gene, 1162

pilG gene, $\mathrm{S} 2.168$

Pina, J. A., 1077

Pinheiro, D. T., S4.3

Pinto beans. See Common bean

Pinto, R., 362

Pinus contorta, $\mathrm{S} 2.48$

Pinus ponderosa

ectomycorrhizal communities in the

Deschutes National Forest, S2.48

ectomycorrhizal communities of Chrysolepis chrysophylla, $\mathrm{S} 2.85$

Pinus radiata, $\mathrm{S} 2.191$

Pinus spp.

evidence for multiple introductions and

clonality in Spanish populations of Fusarium circinatum, 851

host-specific relationship with Suillus, S2.82

Pinus taeda

ectomycorrhizal community, S2.160

effect of altered climate scenarios on loblolly pine decline, S2.26

Pirarungaua stream, S2.68

Pires-Zottarelli, C. L. A., S2.34, S2.68, S2.153

Pislariu, C., S2.92

Pistachio

aflatoxin reduction with biopesticide AF36, S2.175

fungicide resistance in Alternaria spp., S3.11 reducing fungicide applications to control

Alternaria late blight, S3.15

Pisum sativum. See Pea

Pitch canker, 851

Pitcher plants, patterns of fungal diversity in, S2.16

Pityophthorus juglandis (walnut twig beetle),

S2.120

Piveta, G., S2.43

Plant biosecurity

masters-level education, S2.189

next generation sequencing and, S2.33

recent innovations, $\mathrm{S} 2.176$

Plant diagnostic tools, development standards, S2.77

Plant drought resistance, fungal endophytes and,

S2.183

Plant growth promoting rhizobacteria (PGPR)

MBI600, S2.168

Plant immunity

genetic and biochemical characterization of ACC oxidase in, $\mathrm{S} 4.2$ against human pathogens, S2.185

Plant pathology

contributions to food safety, S2.184

effective metrics for documenting research impact, S2.190

integrating foundational topics in an

undergraduate biology curriculum, S2.160

LINK and CANARY technologies for rapid

detection of pathogens, S2.20

online and distance courses and programs, S2.189

role in filling regulatory gaps, $\mathrm{S} 2.180$

teaching tropical plant pathology to a global audience, S2.189

Plant replacement programs, in disease

management, 117

Plant symbioses, symptomless, S2.185

Plant-symbiotic fungi, responses to climate change, S2.182

Plasencia, J. D., S2.176

Plasmodiophora brassicae genetic transformation, 1052 suppression by Serenade, 245

Plasmopara halstedii, S2.63

Plasmopara obducens, S2.109

Plasmopara viticola

identification of genes involved in

pathogenesis on grapevine, 1035

production and release of asexual sporangia, 64

Plata, G., S2.191

Plaza, M., 1188

Pleiotropic drug resistance (PDR)-like ABC genes, $\mathrm{S} 2.78$

Ploetz, J., S2.114

Ploetz, J. N., S2.71

Ploetz, R., S2.40, S2.114

Ploetz, R. C., 400, S2.71, S3.15

Ploper, L. D., 555

Plum pox virus (PPV)

characterization of sour cherry isolates of, 972

comparison of the Pennsylvania and Ontario

survey and eradication programs, S2.51

surveying for in Texas, S2.49

Pluteus section Pluteus, S2.70

Poa alsodes, S2.133

Poa annua, assessment of anthracnose severity,

S2.65

Poa trivialis (roughstalk bluegrass), S3.9

Podosphaera aphanis

characterization of infection of strawberry leaves, S2.10

factors affecting foliar mildew severity in strawberry, 811

geographic and climatic discontinuity in production of cleistothecia, S2.14

temperature regulation of chasmothecia initiation, 717

See also Powdery mildew

Podosphaera macularis

emergence and characterization on hop cultivars with R6-based resistance, $\mathrm{S} 2.38$ mating type distribution and absence of cleistothecia in, S2.161

Podosphaera xanthii

confirming resistance in bottle gourd germplasm, S2.75

fungicide sensitivity, S2.93

Poggi, S., 1012

Poinssot, B., 1035

Polashock, J., 81, S2.114

Polidori, J., 833

Polyethylene glycol-mediated transformation, of

Septoria musiva, S3.7

Polygalacturonases, S2.158

Polymerase chain reaction (PCR)

detection of Harpophora maydis, S2.30

detection of Soybean vein necrosis virus, $\mathrm{S} 2.135$

repetitive PCR, 673
UP-PCR cross-hybridization method, S2.76 use for the speciation of fungi recovered from dried fruits and tree nuts, S2.147

See also Multiplex PCR; PCR-RFLP;

Quantitative PCR; Real-time quantitative

PCR; Reverse transcription PCR

Polymorphic microsatellite markers, for

Phytophthora spp., 1020

Polypores (bracket fungi), improved taxonomic resolution, S2.96

Polysaccharide lyase genes, S2.74

Ponce, K., S2.35

Pond, E., 91

Pooideae, endophyte diversity in, S2.165

Poojari, S., S2.114

Poole, G., 1130, S2.6

Popko, J. T., S2.5, S2.63, S2.126

Poplawsky, A. R., S2.38, S3.13, S3.15

Popper $\mathrm{R}$ package, $\mathrm{S} 2.70$

popP gene, $\mathrm{S} 2.132$

PopS virulence effector, S2.66

Population biology

Cercospora sojina mating-type distributions and genetic diversity on soybean, 1045

evidence for multiple introductions and clonality in Spanish populations of Fusarium circinatum, 851

genetic and phenotypic diversity in Sclerotinia sclerotiorum populations infecting canola, 750 genetic differentiation between populations of Phytophthora alni subsp. uniformis, 190 genetic relationships in an international collection of Puccinia horiana, 1169 genetic structure of Colletotrichum gloeosporioides sensu lato isolates from papaya, 182

influence of hyperparasites on population structure of Cryphonectria parasitica, 1280

population genetic structure of Phytophthora cinnamomi, 91

population genetic structure of Rhizoctonia solani AG-3PT, 862

population structure of Phytophthora nicotianae isolates, 610

signatures of recombination in clonal lineages of the citrus brown spot pathogen, 741

Populus spp., bronze leaf disease, S2.108

Porch, T. C., S2.1

Porras-Alfaro, A., S2.64, S2.87, S2.115, S2.119,

S2.126, S2.146, S2.149

Porter, L., S2.131

Portier, U., 833

Postharvest fruit rot in apple, S2.160

Postman, J., S2.156

Potato (Solanum tuberosum)

aphid feeding behavior and virus resistance in somatic fusions and crosses of $S$.

bulbocastanum and S. tuberosum, S1.3

colonization patterns of Pectobacterium carotovorum subsp. brasiliense, 1268

development of diploid breeding lines with resistance to late blight, $\mathrm{S} 2.49$

effective implementation of diseasesuppressive crops in rotations, $\mathrm{S} 2.77$

effects of seed type and variety on the incidence of Potato virus $Y, \mathrm{~S} 2.46$ identification of a "caulimo-like" virus in germplasm, S2.1

organic potato variety and production trials, S2.25

pathogenicity and aggressiveness of Alternaria alternata, A. solani, and A. triticina, S2.149

Phytophthora infestans infection the Halliwell-Asada pathway in photosynthesis shutdown in compatible interactions with, S2.23

morphological variation of Thai isolates, S2.26 
phytoplasma strains associated with diseases in China, S2.26

Rhizoctonia solani infection

biocontrol with aerobic endospore-forming bacteria strains, S2.17

population genetic structure of strain AG3PT, 862

susceptibility of cultivars to Potato mop-top

virus-induced tuber necrosis, S3.3

Verticillium dahliae infection

effect of green manure crops on, S2.98

incidence and impact in soil associated

with certified seed, 55

population genetic structure, 445

Zebra chip disease

effect on tuber physiology, 419

overview and characterization of, 524

relationship of biochemical responses to

disease progression, $\mathrm{S} 2.154$

Potato common scab, biological control by

Pseudomonas sp. LBUM223, 995

Potato early dying (PED)

effect of composted manure and separated hog

slurry solids on, $\mathrm{S} 2.98$

effect of green manure crops on, S2.98

Potato late blight

development of diploid potato breeding lines

with resistance, $\mathrm{S} 2.49$

evaluation of the blight decision support system

for integrated management of, S2.134

microbial communities associated with the

suppression of in soils from Ecuador, S2.35

See also Phytophthora infestans

Potato leafroll virus (PLRV), S2.38

Potato mop-top virus (PMTV), S3.3

Potato psyllid. See Bactericera cockerelli

Potato soft rot enterobacteriaceae, 1268

Potato spindle tuber viroid (PSTVd), S2.12

Potato viruses

interactions between PVS and PVY, S2.110

molecular mechanisms of eIF4E-mediated

resistance against, $\mathrm{S} 2.8$

Potato virus $S$ (PVS), S2.110

Potato virus $Y$ (PVY), interactions with Potato

virus $S, \mathrm{~S} 2.110$

effects of seed type and variety on the incidence of, S2.46

resistance among varieties for improved seed potato production, $\mathrm{S} 2.166$

Potato zebra chip disease

alternative compounds for management, S3.13

assessment of management and environmental

factors affecting regional occurrence, S2.162

effect on tuber physiology, 419

history in Mexico, S3.12

influence of environmental factors and

management practices on occurrence, 1235

overview, characterization, and discussion of

management, 524

relationship of potato biochemical responses

to disease progression, S2.154

See also 'Candidatus Liberibacter solanacearum'

Potnis, N., S2.50

Potter, J., S2.145

Potvin, A., S2.76

Potyviridae, S3.16

Poudel, R., S2.18, S3.8

Poulin, L., S2.67

Poussier, S., S2.170

Powdery mildew

of cucurbits, efficacy of fungicides with resistance risk for, $\mathrm{S} 2.93$

of grapevine

ontogenesis of conidiation in, S2.93 real-time detection of airborne inoculum, S2.144

of hops, emergence and characterization on cultivars with R6-based resistance, S2.38 of pepper, detection and quantification of

Leveillula taurica growth, 623

of strawberry

factors affecting foliar mildew severity, 811, 1087

temperature regulation of chasmothecia initiation, 717

UV-B radiation for control under greenhouse conditions, S2.9

See also Podosphaera aphanis

Powdery mildew resistance

confirming in bottle gourd germplasm, S2.75

in Cornus florida, S2.98

quantitative phenotyping in grapevine, S2.22

Powell, A. J., S2.64, S2.115

Powell, M., S3.15

Powell, M. J., S2.34, S2.115, S2.130

Power, I. L., S1.9, S2.115

Poza-Carrion, C., 341

Pozza, E. A., S2.133, S2.151

Ppmid1 gene, S2.64

P6 protein, S2.188

Pradhan, S., S2.52

Prasad, V. P. V., S2.59

Prathuangwong, S., S2.25

Pratt, R., S2.171

Pratylenchus vulnus, management on walnut,

S2.159

Predaja, L., 972

Preiss, K., S2.64

Presley, G. H., S2.95

Presser, J., S2.50

Prestat, E., S2.182

Price, P. P., S1.9, S2.116

Prikhodko, Y., 972

PRiME, S2.29

Pringle, A., S2.16

Pringle, H. C., S2.158

Prior, P., S2.3, S2.66

Probst, C., S2.5, S2.105

Proctor, R. H., 400

Proffer, T. J., S2.191

Progeny production curve, relating to the speed of an epidemic, 204

Prom, L. K., S3.3

Propagation systems, percolation-based risk index

for pathogen invasion, 1012

Prosopis velutina (Arizona mesquite), S2.47

Prospero, S., 1020

$\alpha$-Proteobacteria, 524

Pruett, G., S2.40

Pruisner, R., S2.175

Prunus cerasus. See Sour cherry

Prunus crops

evaluation of Meloidogyne incognita

resistance genes in, 833

See also Peach; Sour cherry; Sweet cherry

Prunus replant disease, S2.128

Pruss, G., S2.187

Pruvost, O., S2.67

Pryor, B., S2.27

Pryor, B. M., 741

Pscheidt, J. W., S3.15

Pseudocercosporella capsellae, S2.53

Pseudomonas chlororaphis 30-84

characterizing the promoter of the phenazine

biosynthesis operon, S2.165

function of $\mathrm{acr}$ genes in phenazine regulation and transport, S2.164

regulation of phenazine biosynthesis, S2.155

Pseudomonas fluorescens, 341

Pseudomonas fuscovaginae, S2.10

Pseudomonas marginalis, S2.173

Pseudomonas protegens, S2.28

Pseudomonas protegens Pf-5, S2.121

Pseudomonas spp.

determination of phenazine-producing species in wheat, S2.100 epiphytic survival on Lolium multiflorum and Rumex crispus, $\mathrm{S} 1.3$

fluorescent species associated with cranberry, S2.136

found on Loropetalum stem canker, S2.141

LBUM223 in biological control of potato

common scab, 995

role of humidity and light in Arabidopsis-

Pseudomonas interaction, S2.110

See also Fluorescent Pseudomonas

Pseudomonas syringae

effect of cover crops to reduce disease incidence and severity in squash, S2.147

effect on Salmonella enterica survival on

leaves, 341

Pseudomonas syringae pv. aesculi, S2.67

Pseudomonas syringae pv. phaseolicola, S2.47

Pseudomonas syringae pv. syringae

differentiated phylotype associated with mango, 1115

genetic and phylogenic diversity of strains

from pea, 673

genome sequencing and comparative analysis of strains B301D and HS191, S2.119

Pseudomonas syringae pv. tomato, S2.105

Pseudomonas syringe pv. tabaci, 81

Pseudoperonospora cubensis

differentiation of subpopulations using microsatellite loci, S2.54

influence of environmental factors on aerial concentrations, $\mathrm{S} 2.52$

modeling spatial frailties in survival analysis of epidemics, 216

occurrence of the A2 mating type in the U.S. S2.145

pathogenicity on cucurbits in Costa Rica, S2.16

Pseudoperonospora spp., differentiation using

microsatellite loci, S2.54

Pseudothecia, 281

Pseudotsuga menziesii. See Douglas-fir

Psyllids, testing project in Florida, S2.55

Pterospora andromedea, S2.36

Puccinia arachidis

genetic polymorphism in, S2.115

molecular diversity, S1.9

Puccinia coronata $\mathrm{f}$. sp. avenae, S2.19

Puccinia graminis, S2.36

Puccinia graminis f. sp. tritici

efficacy of disinfestants in killing

urediniospores of, S3.2

functional analysis of conserved genes, S2.164 race TTKSK, 1153

See also Wheat stem rust

Puccinia horiana

genetic relationships in an international collection of, 1169

systemic infection of chrysanthemum, S2.18

Puccinia kuehnii, S2.53

Pucciniales

DNA barcoding from the Brazilian Cerrado, S2.137

molecular phylogenetic diversity and distribution of Mycodiplosis on, S2.102

Puccinia mariae-wilsoniae, S2.128

Puccinia melanocephala, S2.10 See also Brown rust

Puccinia polysora, $\mathrm{S} 1.1$

Puccinia psidii, S2.123

Puccinia punctiformis, S2.15

Puccinia recondita f. sp. tritici, S2.80

Puccinia spp., on wheat in the Ecuadorian highlands, S2.108

Puccinia striiformis, analysis of interregional

dispersal in China, S2.81

Puccinia striiformis f. sp. tritici association of SNP markers to avirulence genes, S2.156

early monitoring based on infrared spectroscopy, S2.80 
evolution of virulence on genes for adult-plant resistance in wheat, S2.97

identification of Berberis spp. as alternate

hosts, 927

local dispersal from single source lesions, S2.41

population structure and genomics, S2.184

races identified in the U.S. in 2012, S2.155

screening winter wheat germplasm for

resistance, $\mathrm{S} 3.5$

on wheat in the Ecuadorian highlands, S2.108

Puccinia triticina

operational warning in winter wheat, S2.38

population divergence correlated with wheat evolution, S2.84

Puccinia triticina resistance

evaluation of Triticum durum germplasm for, S3.2

histological characterization, S2.37

screening winter wheat germplasm for, S3.5

seedling resistance in Thatcher isolines, S3.3

Puckett, R. D., S2.175, S3.14, S3.15

$\mathrm{Pu}, \mathrm{L} ., \mathrm{S} 2.116$

Pumphrey, M., S2.164

Pumpkin

chemical and biocontrol agents for manage-

ment of Xanthomonas cucurbitae, S2.144

detection of Xanthomonas cucurbitae in seed, S2 119

Punctodera spp., in golf course greens, S2.103

Pun, M., S2.97

Puppala, N., S3.14, S3.16

Purdie, L., S2.76

Puri, K. D., S2.78

Purple nutsedge (Cyperus rotundus), 792

Purple seed stain, S1.9

Purvis, M. A., S1.9, S2.116

'Pusa Ruby' tomato, S2.9

Putman, A., S2.14, S2.116

Putman, A. I., S4.1

$\mathrm{Pu}, \mathrm{X} ., \mathrm{S} 2.82$

PvInv gene, 1035

PvLac gene, 1035

PvNuo gene, 1035

Pye, M. F., S2.122

Pyle, J. D., S2.138

Pyraclostrobin, 690

Pyrenophora teres f. maculata, S2.74

Pyrenophora tritici-repentis

evaluation of spring wheat germplasm for resistance to race $1, \mathrm{~S} 2.4, \mathrm{~S} 3.1$

lipid profiles in wheat cultivars resistant and susceptible to tan spot, 74

Pyricularia, Pyricularia/Magnaporthe

nomenclature, S2.173

Pyricularia oryzae, $\mathrm{S} 2.124$

Pyrimethanil resistance, in Penicillium expansum

from apple, S2.22

454-Pyrosequencing, 1020

Pythium aphanidermatum, S3.14

Pythium brassicum, $\mathrm{S} 2.138$

Pythium damping-off, evaluation of products for

greenhouse management, S2.13

Pythium insidiosum, $\mathrm{S} 2.50$

Pythium iwayamai, S2.65

Pythium seed and root rots of soybean, effects of

salinity on, S1.10

Pythium spp.

characterization of species associated with

Prunus replant disease, S2.128

effect of crop rotation on population com-

position in soybean fields, S2.150

exploring the characteristics of Pythium

communities, S2.159

fungicide sensitivity of species affecting corn

and soybean in Iowa, S3.6

genomics-based diagnostic marker

development for, S2.65

impact on floriculture crops in North Carolina, S1.7 isolation from stream ecosystems, S4.2 pathogenicity affecting corn and soybean, S2.92

Qian, G., S2.168

Qiao, T.-M., 135

Qiao, Y., S2.188

Qin, R., S2.116

Qiu, C., S2.21, S2.27, S2.117

Qiu, J., S2.116, S2.184

Qiu, W., S2.32

QoI resistance

in Botrytis cinerea from eastern U.S. vineyards, S4.1

characterization and molecular diagnosis in

Cercospora sojina isolates, $\mathrm{S} 2.166$

competitiveness of field QoI-resistant

Alternaria alternata isolates, S2.152

evaluation of Rhizoctonia solani AG 1-IA and

Rhizoctonia species, S2.24

monitoring in Rhizoctonia solani isolates causing rice sheath blight, S2.106

QTL mapping

to identify new sources of rice sheath blight resistance, $\mathrm{S} 2.24$

of wheat stripe rust resistance in spring wheat, S2.42

Quantitative PCR (qPCR)

detection and identification of Ralstonia solanacearum, S2.140

detection of Fusarium oxysporum $\mathrm{f}$. sp. phaseoli in bean seeds, S2.153

detection of Fusarium oxysporum in grated melon genotypes, 802

detection of Harpophora maydis, S2.30

temporal evaluations on the wheat stem rust infection process on barley, S3.9

See also Real-time quantitative PCR; Taqman real-time PCR

Quantitative pyrosequencing, to dissect complex

pathogen-pathogen interactions, S2.94

Quantitative resistance, to Fusarium head blight in elite spring barley, 1252

Quarantine fungi, detecting with DNA barcoding,

1103

Ouercus agrifolia (coast live oak), S2.29

Quercus alba. See White oak

Quercus hypoleucoides, S2.62

Quesada, L., S2.117

Que, Y., S2.84

Qu, F., S2.26

Quinoa (Chenopodium quinoa)

detection of Peronospora variabilis in seeds, S2.191

plant growth promoting characteristics of

Bacillus species associated with, S2.144

Quinoa downy mildew, S2.191

Quinolone alkaloids, S2.68

Quinone outside inhibitor (QoI) fungicides effect on Fusarium head blight in soft red winter wheat, S2.33

sensitivity of Cercospora kikuchii to, S1.9

See also QoI resistance

Quintanilla, L., S2.60, S2.186

Quiroz-Flores, A., S2.59

Quito-Avila, D. F., S2.72, S2.117

Quitugua, T., S2.176

Quorum-sensing transcription factor, aviR, 427

Rabie, A. A., S2.154

Racette, G., S2.147

Rachilla-seed interface, xylem discontinuity in wheat, 682

Radmer, L., 43

Radwan, O., S2.117, S3.8

Raffaelea lauricola, on avocado, S2.40, S2.114

Raffaelea quercus-mongolicae, S2.74

Raghavan, C., S2.19

Rahman, A., S2.117
Rahman, M., S2.118, S4.3

Raid, R., S1.3

Raid, R. N., S2.29

Rajasekaran, K., S2.127

Raj, Y., S2.152

Rakotondrafara, A. M., S2.8

Rallos, L., S4.3

Ralstonia solanacearum

contribution of extracellular DNases to

virulence, S2.147

degradation of hydroxycinnamic acids, S2.86

detection using portable surface plasmon

resonance technology, S2.167

effect of transitional organic product practices on, 792

evaluating tomato rootstocks for resistance in North Carolina, S2.134

genetic variability in Brazil, S2.126

host adaptation in, $\mathrm{S} 2.3$

identifying host targets for type III effectors in Solanum lycopersicon, S2.73

improved multiplex PCR and qPCR detection and identification, S2.140

infection of highbush blueberry, S2.112

PopS virulence effector and the suppression of SA-mediated defenses, S2.66

strain P673, analysis of virulence factors, S2.17, S2.18

T3SS activation in planta, S2.32

See also Bacterial wilt

Ramadugu, C., S2.55, S2.72, S2.118, S3.14

Ramegowda, Y. B., S2.60

Ramirez-Del Villar, A., S2.118

Ramirez-Escobar, U. M., 862

Ramirez, G., S2.119

Ramirez, G. M., S2.11, S2.59

Ramírez-Malagon, R., S2.41, S2.112

Ramorum blight, S2.124

Rampersad, S. N., 182

Ramsubhag, A., S3.11

Ramularia eucalypti species complex, S2.153

Ramulosis of cotton, S2.113

Randall, J., S2.138, S3.14

Ranjan, A., S2.118

Ransom, J., S3.5

Rapicavoli, J., S2.119, S2.171

Rapid blight, new occurrences, S2.107

Raputia heptaphylla, S2.68

Raruang, Y., S1.4, S2.45

Rascher, U., S2.128

Rashed, A., 1235, S2.154, S2.162

Raspberry (Rubus idaeus), isolation and detection of Phytophthora rubi, S2.139

Raspberry bushy dwarf virus (RBDV), S2.117

Raspberry ringspot virus (RpRSV), S2.49

Rathayibacter agropyri, S2.92

Ratoon stunt, S2.84

Raudabaugh, D. B., S2.119

Ravanlou, A., S2.119

Ravindran, A., S2.79, S2.119

Rayamajhi, M. B., S2.123

Rayapati, N., S2.20

Razor Ex BioDetection System, S2.9

Rccl gene, 575

Reactive oxygen species assessing the scavenging activity of Diplodia pinea, $\mathrm{S} 2.132$ quantification using the fluorimetric probe Amplex Red, S2.24

Real-time quantitative PCR (qRT-PCR) assessment of Sphacelotheca reiliana interactions with maize seedlings, S2.7 comparison of protocols for the monitoring of asymptomatic olive infections by Verticillium dahliae, 1058

detection and differentiation of Colletotrichum species causing soybean anthracnose, S2.164

detection of Agrobacterium vitis, 633 
detection of Fusarium oxysporum in grated melon genotypes, 802

detection of Leveillula taurica, 623

evaluation of experimental fungicides against Septoria tritici, S2.10

generation of full sequence reads from small amplicons, S2.8

magnetic capture hybridization real-time PCR assay for detecting Agrobacterium vitis, 633 temporal evaluations on the wheat stem rust infection process on barley, S3.9

See also Quantitative PCR; Taqman real-time PCR

Rebollar-Alviter, A., S2.119, S2.134

Recombinase-based in vivo expression

technology (RIVET)

identification of Salmonella enterica genes with a role in persistence on lettuce leave, 362

to monitor Salmonella AI-2 signaling, 352

Red blotch disease, 1069

Reddy, M. S., S2.168

Redfern, J., S2.115

Redinbaugh, M., S2.171

Red stele of raspberry, S2.139

Reduced risk fungicides, control of carrot foliar

diseases, S3.5

Reed, S., S2.120

Ree, R., S2.48

Reeves, G., 472

Reges, J. T. A., S3.5

Rehner, S. A., 400

Reid, C., S2.69

Reid, C. L., 427, 633

Reineke, A., 1001

Reinhold, L., S2.120

Reisch, B., S2.22

Reiter, M. S., S2.120

Remesal, E., 479

Repetitive polymerase chain reaction (rep-PCR), 673

Reproduction curves, 204

Requena, N., S2.187

Reschke, M., S2.13

Residue management

effect of levels of wheat residue on severity of Stagonospora nodorum blotch, S2.95 effect on Goss's wilt of corn, S2.94

Resistance $(R)$ genes comparative analysis of the disease resistance gene space of rosaceous species, S2.20

evaluation of Meloidogyne incognita resistance genes in Prunus, 833

functional analysis of Pid3-A4 by allele mining in common wild rice, 594

identification and mapping of a wheat resistance gene to an unadapted isolate of Colletotrichum cereale, 575

identification of blast resistance gene $P i-h k l$ in Japonica rice landrace, 1162

identification of homologues in common bean using nucleotide-binding site domains, 156

identification of Rpg5 gene in wheat stem rust resistance, 1153

in silico identification and characterization in switchgrass, S2.46

Resistance inducers, field treatment of grapevine

bois noir, 785

Resistance to Colletotrichum cereale 1 (Rccl)

gene, 575

Restrepo, S., S2.23

Reverse transcription PCR (RT-PCR) detection of High plains virus, S2.9 end-point RT-PCR for the detection of High plains virus, S2.9

one-step detection and differentiation of sweet potato potyviruses, $\mathrm{S} 2.76$

See also Multiplex one-step RT-PCR

Reyes, C., S2.91
Reyes Chin-Wo, S., S2.101

Reyes, R., S2.44

Reynolds, D. R., S2.19

Rezende, J., S2.120

Rezk, A., S2.4

Rhizamonas, S2.46

Rhizobacteria, attenuation of Curtobacterium

flaccumfaciens pv. flaccumfaciens in common bean, S2.91

Rhizobacteria Jdm1, S2.159

Rhizobiaceae, 524

Rhizoctonia damping-off, evaluation of products

for greenhouse management, S2.13

Rhizoctonia root rot

of apple, anaerobic soil disinfestation in suppression of, S2.60

identification of resistance in barley, S2.3

in sugar beet, management, S2.73

Rhizoctonia solani

Bacillus subtilis induced tolerance in cotton, S2.94

biocontrol with aerobic endospore-forming bacteria strains, S2.17

characterization of anastomosis groups on potato, S2.96

comparative genomic analyses, S2.98

control by rice-associated strains of Bacillus spp., S1.9

diversity in association with canola, wheat, and pea, S2.111

efficacy of Bacillus in biocontrol with organic rice, $\mathrm{S} 2.168$

evaluation of control with PGPR strain

MBI600 in combined use with azoxystrobin, S2.168

management in sugar beet, S2.73

monitoring azoxystrobin resistance in, S2.106

transcriptional profiling of sclerotia formation in, S2.144

See also Brown patch; Sheath blight

Rhizoctonia solani AG-5, anaerobic soil

disinfestation in suppression of, S2.60

Rhizoctonia solani AG11, spatial analyses, S1.10

Rhizoctonia solani AG1-1A

effect of Brassica juncea cover cropping on, S1.5

evaluation for resistance to QoI fungicides, S2.24

on peanut in Arkansas, S2.42

precision concept for management, S2.137 See also Rice sheath blight

Rhizoctonia solani AG2-2 IIIB, importance of soil moisture and isolate origin on disease severity,

$\mathrm{S} 2.102$

Rhizoctonia solani AG-3PT, 862

Rhizoctonia spp.

analysis of the expansion segment D11 of 28S rDNA, S2.50

evaluation for resistance to QoI fungicides, S2.24 glyphosate application to cereal cover crops to manage onion stunting, S2.131

Rhizomonas, S2.46

Rhizomorpha corynephora, S2.85

Rhizopogon spp., S2.36

RhizoVital 42 fl., 1001

Rhododendron, ramorum blight, S2.124

Ribeiro Junior, P. M., S2.91

Rice (Oryza sativa)

analysis of rice PDR-like ABC transporter genes in sheath blight resistance, S2.78

characterization of DAMP induced innate immune response, S2.118

detection of Xanthomonas oryzae pathovars

from seed, S2.152

dynamics of Southern rice black-streaked dwarf virus in, 509

efficacy of Bacillus as biocontrol agents for sheath blight and narrow brown leaf spot, S2.168 efficacy of seed treatment fungicides for control of seedling diseases, S2.168

hemibiotriophy in the rice blast system, S2.186

identification of blast resistance gene $P i-h k l$, 1162

identifying novel bacterial disease resistance sources for, S2.19

impact of temperature on expression of TAL effector-activated genes, S2.30

phenylalannine ammonia lyase 4 gene

associated with disease resistance, S2.89

reaction of cultivars to Ustilaginoidea virens infection, $\mathrm{S} 1.10$

resistance to viruses transmitted by small brown planthoppers, $\mathrm{S} 2.184$

Rice black streaked dwarf virus infection and elevated levels of hydrogen peroxide, S2.163

Rice grassy stunt virus resistance induced in transgenic plants, 513

sheath blight control by rice-associated strains of Bacillus spp., S1.9

Rice black streaked dwarf virus (RBSDV),

S2.163, S2.184

Rice blast

global efforts in managing, S2.184

hemibiotrophy, S2.186

interactome of pathogenicity factors, S2.81

See also Magnaporthe oryzae

Rice blast resistance genes

functional analysis of Pid3-A4, 594

identification of $P i$ - $h k l$ in Japonica rice

landrace, 1162

molecular characterization, S2.88

Rice, C. W., S2.182

Rice false smut, S2.184

Rice grassy stunt virus (RGSV), 513

Rice resistance genes, identification via targeted

genome editing, S2.13

Rice sheath blight

effect of Brassica juncea cover cropping on, S1.5

efficacy of Bacillus in biocontrol with organic rice, $\mathrm{S} 2.168$

evaluation of control with PGPR strain MBI600 in combined use with azoxystrobin, S2.168 monitoring azoxystrobin resistance in, S2.106 precision concept for management, S2.137

Rice sheath blight resistance, QTL mapping to

identify new sources in recombinant inbred

lines, S2.24

Rice stripe virus (RSV), 513, S2.184

Riddle, J. M., S2.150

Ridenour, J., S2.121

Ridenour, J. B., S1.9, S2.120

Rideout, S., S2.120, S2.173

Riley, D., S2.137

Riley, M. J. J., S2.179

Riley, R., S2.101, S2.121, S2.181

Riley, R. W., S2.146

Ring nematode (Mesocriconema xenoplax), management on walnut, S2.159

Riosmena-Rodriguez, R., S2.5

Rioux, R., S2.121

Riquelme, M., S2.186

Risk aversion, accounting for in calculating

fungicide dose decisions, 666

Ristaino, J. B., S2.189

Ritchie, D., S2.122

Ritchie, D. F., S2.135

Ritzenthaler, C., S2.51, S2.188

Rivard, C., S3.8

Rivas-Plata, E., S2.149

Rivera Beede, I. M., S2.121

Rivera-Vargas, L. I., S2.130, S3.13, S3.16

RMia gene, 833

RNA interference (RNAi)

conferring resistance against Rice grassy stunt virus, 513

transfection to prevent infection, S3.9 
RNA silencing

production of RNA-silencing repressors by Phytophthora, S2.188

in viral infections of maize, S2.187

RNA viruses, evolutionary genetic factors in the

emergence and spread of, S2.179

Roasted milo, S3.13

Roatti, B., 1227

Roberson, R. W., S2.44, S2.93

Roberson, S. L., S1.9, S2.121

Roberts, D. P., S2.98, S2.121

Roberts, J., S2.122

Robertson, A., S2.35, S2.93, S3.5, S3.6, S.36

Robertson, A. E., S2.88, S2.92, S2.123, S2.131, S2.175, S3.1

Robertson, C., S2.55, S2.158

Robertson, C. J., S2.31, S2.57

Robertson, C. L., S1.9, S1.11, S2.116, S2.133

Roberts, P., S1.3

Roberts, P. D., 1243, S2.36, S2.40

Roberts, S. M., S2.122

Robert, V. A. R. G., 400

Robin, O. A., S2.146

Robinson, M. D., 98

Roca, M. M., S2.177

Rocha, S. C. O., S2.68

Roche, D., S2.3

Rochet, J., S2.124

Roda, A. L., S3.15

Rodrigues, J. V., S3.13, S3.15, S3.16

Rodriguez, A., S2.43, S2.122, S2.188

Rodriguez-Alvarado, G., S2.15, S2.122, S2.136

Rodriguez, D., S2.67

Rodríguez, J., S2.151

Rodríguez, L., S2.122

Rodriguez-R. L. M., S2.67

Rodriguez-Zaragoza, S., S2.59

Roeschlin, R. A., 555

Rogers, E. E., S2.78

Roguing, in disease management, 117

Rohila, J., S2.4, S3.1

Rohrig, E., S2.141

Rojas, A., S2.123, S2.150

Rojo-Baez, I., S3.11

Roldan-Ruiz, I., 1169

Rollins, J. A., S2.81, S2.156

Rolshausen, P., S2.148, S3.12

Romanazzi, G., 785

Romero, M. P., S2.123

Rondon, M. N., S2.113

Rondon, S. I., S2.38

Rong, X., S2.123

Rooney, A. P., 400, S2.71

Root diseases, measuring suppression in response

to a compost water extract, 255

Root endophytes, production of acid protease,

S2.92

Root-knot nematodes

control with Aspergillus niger-Y61, S2.116

effect of parasitism on host gene silencing, S2.155

emerging problems with minor species, 1092

host-derived RNA interference targeted to parasitism gene 16D10, S2.129

isolation and characterization of rhizobacteria Jdm1 antagonist, S2.159

management with tall fescue rotations prior to peach orchard establishment, S2.104

MiD05 parasitism gene, 175

response of African horned cucumber to, S2.144

segregation and mapping of quantitatively inherited traits affecting parasitism, 935

See also Meloidogyne incognita

Root mycobiomes, S2.115

Root rot

on blueberry in Mexico, S2.119

root rot fungi, 583

on wheat, survey in South Dakota, S2.48
Roots

internal colonization by E. coli $\mathrm{O} 157: \mathrm{H} 7,333$ microbiome shifts associated with reduction of pathogen root colonization, 23

root-knot nematode infection and the MiDO5 parasitism gene, 175

Roper, C., S2.21

Roper, M. C., S2.119, S2.171

Rosa, B. A., 326

Rosaceous species, comparative analysis of the disease resistance gene space of, S2.20

Rose, biocontrol of Botrytis cinerea with

phillospheric yeasts on cut roses, S2.85

Rose, L. J., S2.72

Rosen, B., 156

Rosen, C., 34

Rose rosette disease (RRD), S1.3

Rose rosette virus (RRV), S1.3

Rosique-Gil, E., S2.152

Ross-Davis, A. L., S2.39, S2.123

Rossi, V., 64

Rosskopf, E., S2.61

Rosskopf, E. N., 792

Rossman, A. Y., S2.59, S2.89, S2.125, S2.150, S2.172

Rotenberg, D., S2.11, S3.1, S3.2, S3.7

Rothrock, C. S., S1.9, S1.10, S2.42, S2.137, S2.150

Rothwell, N. L., S2.79

Rotich, F., S2.124

Rott, M., S2.124

Roubtsova, T. V., S2.124, S2.163

Roughstalk bluegrass (Poa trivialis), S3.9

Rouse, D., S2.25

Roux, B., S2.170

Rowhani, A., 1069, S2.3, S2.4

Roy, A., 488, S2.124

RoyChowdhury, M., S2.125

Roy, D., 326, S2.125

Roy, M., S2.58, S2.124

RPB2 gene, 479

Rpg5 gene, 1153

Rpg4-mediated wheat stem rust resistance, 1153

Rubber tree (Hevea brasiliensis)

basidiomycetous endophytic community, S2.90

delimitation of tropical endophyte Diaporthe species from, S2.134

South American leaf blight of, S2.61

Rubus idaeus, isolation and detection of

Phytophthora rubi, S2.139

Rubus yellow net virus (RYNV), S2.35

Rucker, K., S2.149

Rudgers, J., S2.165, S2.183

Ruess, R., S2.182

Ruggeri-Gomes, J., S2.67

Ruhl, G. E., S3.3

Rumex crispus, $\mathrm{S} 1.3$

Runoff water, disinfesting from contamination

with Phytophthora ramorum, S2.77

Rupe, J., S1.2, S2.28, S2.80

Rupe, J. C., 1045, S1.9, S2.123, S2.150

Rupp, R., 1130

Rush, C. M., 1235, S2.154, S2.162

Rush, M. C., S1.9

Russian wheat aphid (Diuraphis noxia), S2.87

Russo, J., 1204

Russo, T. R., S2.60

Rust fungi

DNA barcoding from the Brazilian Cerrado, S2.137

See also Individual rusts

Rust resistance, simple sequence repeat DNA

markers linked with in common bean, S2.132

Rusty mottle of sweet cherry, 1287

RXLR effectors, S2.4, S2.188

Ryan, K. L., S4.3

Rychlik, M., 1252

Rye (Secale cereale), as a cover crop to reduce incidence of Pseudomonas syringae, S2.147

Ryu, J. S., S2.95
Saalau-Rojas, E., 900, S2.83, S2.171

Saari, S., S2.185

Sabanadzovic, S., S1.6, S2.2, S2.87, S2.125

Sackett, K., S2.41

Saeed, H., S2.124

Saenz-Hidalgo, H. K., S3.12

Saharan dust storms, microbial diversity and emerging pathogens, S2.83

Saif, A., S2.140

Saito, S., 1180

Sakai, J., 509

Salamov, A., S2.121

Salazar, A., S2.11

Saleh, A. A., S2.39, S2.125

Salgado, J. D., S2.173

Salgado-Salazar, C., S2.125

Salicaceae, S2.142

Salicylic acid

induction of plant defenses in perennial ryegrass, S2.117

salicylic acid-mediated defense network in strawberry, S2.82

Salinity

effect on Pythium seed and root rots of soybean, $\mathrm{S} 1.10$

impact of Ceratocystis fimbriata wilt on mango, S2.100

impact on Ceratocystis fimbriata wilt in mango, S2.100

interactions with soybeans and Soybean mosaic virus, $\mathrm{S} 2.76$

molecular and cellular responses of date palm roots to salinity stress, $\mathrm{S} 3.8$

Salix, ectomycorrhizal fungi, S2.182

Sallee, J., S2.33

Salleh, B., S2.98

Salmonella

activation of the plant immune system, S2.95 interactions with plants and associated microbiota, 316

Salmonella enterica

colonization of plants, S2.185

effect of resident leaf bacteria on immigrant cell survival, 341

effects of fumigation and bactericide applications, S2.120

factors affecting proliferation on tomato, S2.12

identification of genes with a role in persistence on lettuce leaves during cold storage, 362

insect transmission, S2.171

role of motility in root colonization, $\mathrm{S} 2.56$ transmission by flies, S2.185

Salmonella enterica Typhimurium, effect of

soil management on movement in tomato plants, 381

Salmonella enterica Typhimurium SL1344, plant immunity against, 326, S2.185

Salmonella spp., consequences of disrupting AI-2

signaling on interactions with soft rots, 352

Salomon, C. E., 34

Salt marshes, Fusarium species composition, S2.40

Salt stress, S1.6

Salustiano, M. E., S2.113

Salvadora spp., S2.38

Salvatierra, J., S2.114

Samiksha, F., S2.157

Samuels, G. J., S2.59

Sanchez, A., S1.1, S2.126

Sánchez, G., S2.151

Sanchez, M., S2.137

Sanchez-Pale, J. R., S2.134

Sanchez-Perez, A., S2.49

Sandberg, D. C., S2.126

Sanders, H., S2.37

Sandona, K., S2.64, S2.115, S2.126

Sangchote, S., S2.136 
Sang, H., S2.5, S2.63, S2.126

Sanogo, S., S2.138, S3.14, S3.16

Santiago, T. R., S2.126

Santos, M. M. D., S2.127

Sap flow velocity, effect of Ceratocystis smalleyi infections on, 565

Sapkota, S., S2.127

Saponins, S1.9

Sarcodon, S2.53

Sarmiento, C., S2.48

Sarmiento, L., S2.106

Sasaya, T., 513

Satellite RNAs, of Grapevine fanleaf virus, 1180

Sattler, S. E., S3.3

Sauer, K., S2.64

Savage, J., S2.41

Saville, B., S2.26

Sayler, R., S2.127

Scab. See Fusarium head blight

Scalliet, G., 880

Scandiani, M. M., 400

SCAR markers. See Sequence-characterized

amplified region markers

Scauflaire, J., 400

Schadt, C., S2.18

Schaefer, A., S2.18

Schaffer, B., S2.114

Schardl, C., S2.13

Schardl, C. L., S2.44, S2.101, S2.109, S2.165

Schaub, M., S2.22

Schaub, T., S2.138, S3.14

Scheets, K., S2.187

Schena, L., 610

Schilder, A. C., S2.127

Schilling, J. S., S2.95

Schisler, D. A., S2.123, S2.127

Schlub, R. L., S2.10, S2.128

Schlund, S. A., S2.128

Schlüter, K., 682

Schmidt, L. S., S2.128

Schmittgen, S., S2.128

Schmitt-Keichinger, C., S2.188

Schmitt, M., S2.103

Schnabel, G., S2.43, S2.51, S2.128

Schneider, R., S2.158

Schneider, R. W., S1.9, S1.11, S2.116, S2.133

Schneider, W., S2.33, S2.124, S2.139, S2.176

Schneider, W. L., S2.33

Schneweis, B., S3.7

Schoch, C. L., S2.128

Schoebel, C. N., 1020

Schoelz, J., S2.7, S2.43, S2.188

Schoelz, J. E., S2.122, S2.189

Schoenlein-Crusius, I. H., S2.68

Scholthof, H. B., S2.105

Scholthof, K. B. G., S2.88, S2.138

Schreier, S., S2.128

Schroeder, B. K., S2.8, S2.37, S2.92

Schubert, T., S2.141

Schuenzel, E., S2.23, S2.44

Schultheiss, H., S2.77

Schultz, K., S2.102

Schurt, D. A., S2.91

Schuster, G., S2.177

Schutte, T., 281

Schwartz, H., S2.142, S3.17

Schweigkofler, W., S2.129

Schweri, K., S2.129

Sciumbato, G., S2.80, S2.158

Sclerophthora, identification and diagnosis,

S2.179

Sclerotinia homoeocarpa

adaptability to multiple fungicide pressures in heterokaryons, S2.73

expression of germin-like protein gene in response to infection by, $\mathrm{S} 2.121$

field selection of DMI insensitive isolates, $\mathrm{S} 2.5$ genetic determinants of fungicide detoxification in, S2.63 genetic mechanisms of decreased sensitivity to iprodione, S2.126

molecular and diagnostic assays for fungicide resistance in, S2.63

signatures of global dispersal and population structure, S2.116

stimulation of radial growth in vitro, $\mathrm{S} 2.52$

taxonomic placement, S4.1

See also Dollar spot

Sclerotinia minor, S2.27

Sclerotinia rolfsii, $\mathrm{S} 2.162$

Sclerotinia sclerotinia

carbon sources in relation to pathogenicity on Valencia peanut, S3.14

factors affecting selection for resistance in common bean, S3.17

genetic and aggressiveness variation in bean fields in Brazil, S3.9

Sclerotinia sclerotiorum

characterization of isolates for soybean for aggressiveness and mycelial compatibility, $\mathrm{S} 2.138$

field trial evaluation of resistance in annual bedding plants, S2.52

genetic and phenotypic diversity in populations infecting canola, 750

genetic variation and aggressiveness in, S2.117

high density genotyping, S2.21

identification of resistance loci in a perennial relative of soybean, $\mathrm{S} 2.24$

oxalate decarboxylase gene in the early infection process, $\mathrm{S} 2.81$

prevalence of inversion negative and inversion positive MAT alleles, S2.27

Sclerotinia stem rot. See Sclerotinia sclerotiorum

Sclerotium cepivorum, S2.112, S2.173

Sclerotium rolfsii

effect of planting date and early season prothiconazole applications on, S2.149 identifying mycelial compatibility groupings in, 479

optimum temperature for growth and colonization on peanut leaves, S1.10

Sclerotium root-rot, identifying mycelial

compatibility groupings, 479

Scoglio, C. M., S2.59, S3.4

Scotton, M., 802

$\mathrm{SdhB}$ gene, $\mathrm{S} 2.191$

Seabloom, E. W., S2.34

Seabra, S. S., S2.91

Seaman, A., S2.33

Seaman, M., S2.5

Searle, C. L., S2.15

Sebacina vermifera, $\mathrm{S} 2.92$

Secoviridae, $\mathrm{S} 2.145$

Seedborne pathogens

application of next generation sequencing in the development of diagnostic tools, S2.140 evaluation of seed wash DNA extraction method, S2.140

transmission of Soybean mosaic virus, 941

Seed endophytes, of the alpine tundra in

Colorado, S2.146

Seedling blight of soybean, S2.31

Seedling yellows, S2.56

Seed potatoes, resistance to Potato virus $Y$

infection, S2.166

Seed treatments

bacteriophage treatments for the control of bacterial pathogens, S2.174

development and formulation of seed treatment combinations, S2.174

effect on Verticillium wilt of spinach, 268

efficacy of fungicides for control of rice

seedling diseases, S2.168

microbial, S2.174

nematode-protectant, S2.174

new technologies, S2.174 in peanut disease management in Nicaragua, S3.12

physiological benefits of, S2.174

Seed wash DNA extraction method, S2.140

Seem, R., S2.14, S2.22

Seem, R. C., 717, S2.10, S2.93

Seetha, A., S2.104

Seeve, C., S2.155

Segoviano, M. A., S2.19

Seidl, A. C., S2.129, S3.6

Seifert, K. A., S2.103, S2.172

Seijo, T. E., S2.130

Sekimoto, S., S2.130

Sela (Saldinger), S., 362

Sempere, R. N., 1188

Sendín, L. N., 555

Sengoda Gounder, V., S2.130

Sensor-based plant pathogen detection, S2.176

Seo, S. T., S2.74

Septoria leaf blotch (SLB), operational warning in

winter wheat, S2.38

Septoria leaf spot, control in tomato, S2.101

Septoria musiva

PEG-mediated transformation, S3.7

prediction of long-term field resistance of hybrid poplars, S2.116

Septoria passerinii, 600

Septoria speckled leaf blotch resistance, 600

Septoria tritici

operational warning in winter wheat, S2.38

real-time quantitative PCR assay for the evaluation of experimental fungicides against, $\mathrm{S} 2.10$

Septoria tritici leaf blotch, calculating fungicide dose decisions on winter wheat, 666

Sequence-characterized amplified region (SCAR) markers

detection of brown patch pathogens from turfgrass, $\mathrm{S} 2.76$

detection of Macrophomina phaseolina in cluster bean, $\mathrm{S} 2.25$

Sequence-tagged site (STS) markers, fine mapping of leaf rust resistance gene $\mathrm{LrZH} 84,169$

Serenade, 245

Serfontein, S., 281

Serpi, M., S2.58

Serratia marcescens, S2.15

Serrato-Diaz, L., S2.130, S3.16

Sessa, G., S2.24

Sétamou, M., S2.75, S2.86

Setia, R., S2.73

Setosphaeria turcica, 641

Sexton, M., S2.120

Sexton, Z., S2.130

Seybold, S., S2.163

Shaffer, J. P., S2.48, S2.130, S2.161

Shagbark hickory (Carya ovata), 565

Shah, D. A., 906, S2.131

Shamoun, S., S2.82, S2.131

Shang, J., 594

Shankle, M., S1.1

Shan, T., S2.184

Shantharaj, D., S2.131

Shao, J., 488, 920, S2.124, S2.140

Sharafaddin, A. H., S2.125

Sharma, J., S2.135

Sharma Poudyal, D., S2.131

Shaver, J. B. R., S2.131

Shaw, B. D., S2.60, S2.186

Shaw, J. D., S2.123

Shaw, M. W., 666

Sheath blight of rice analysis of rice PDR-like $\mathrm{ABC}$ transporter genes in resistance, $\mathrm{S} 2.78$ effect of Brassica juncea cover cropping on, S1.5 suppression by rice-associated strains of Bacillus spp., S1.9

See also Rhizoctonia solani 
Shen, H., S2.82

Shen, W., S2.83, S2.84

Shepherd, L., S2.17

Sherwood, P., S2.132

Shew, B., S1.7, S2.85

Shew, D., S2.189

Shier, W. T., S2.176

Shiitake (Lentinula edodes), S2.105

Shimizu, T., 513

Shim, W. B., S2.167

'Shin-chunaga' wheat cultivar, 575

Shin, S. H., S2.132

Shi, Q., S2.132

Shirofugen stunt disease, 293

Shishkoff, N., S2.132

Shivas, R., S2.94, S2.150, S2.179

Shi, X., S2.132

Shneyder, Y., 972

Shoji, J., S2.92

Short, D. P. G., 400, S2.54, S2.71, S2.133

Short interfering RNAs (siRNAs), role in viral

infections of maize, S2.187

Shotgun poplar disease, S2.35

Showmaker, K. C., S2.35

Shrestha, B. K., S1.9

Shugart, H., S2.119

Shu, X., S2.133

Shymanovich, T., S2.133, S2.165

Siambi, M., S2.104

Siciliano, M. F., 555

Sida micrantha mosaic virus, 436

Sida spp.

as an inoculum source for tomato-infecting

Begomoviruses, 436

infection by monopartite begomoviruses, $\mathrm{S} 2.23$

Sierotzki, H., 880, S2.106

Sikdar, P., S2.133

Silliker, M., S2.90

Silva, E., S2.158

Silva, E. C., S2.133

Silva, K. J. P., S2.134

Silva, M. G., S2.133

Silva, M. L. O., S2.151

Silva-Rojas, H. V., S2.119, S2.134, S3.12

Silverman, E. J., S2.134

Silver nanoparticles, as a novel nematicide in

turfgrass, $\mathrm{S} 1.2$

Simento, S., S2.123

Simmons, H. E., S2.134, S2.153

Simple sequence repeats (SSRs), specific

discrimination of Fusarium proliferatum, S2.99

Sims, K. R., 545

Sinapis alba, 841

Singh, P., S2.78, S3.1

Singh, R., S1.8, S2.23, S2.106

Singh, S., S3.17

Single chain variable fragment (scFV) antibodies, S2.165

Single chain variable fragment (scFV) phage, S2.158

Single nucleotide polymorphisms (SNPs), genetic variation in isolates of Phytophthora nicotianae, 610

Sink, S., S2.71

Sinsabaugh, R., S2.60, S2.115, S2.146

Sisterson, M. S., 117

Sit, T. L., S2.85

Skaltsas, D. N., S2.134

Skarp gene, 129

Slemmons, C. R., S2.7, S2.8

Slippery skin of onion, S2.173

Slot, J. C., S2.177

Small brown planthoppers, S2.184

Small, I. M., S2.134

Small noncoding RNAs, S2.187

Small RNAs (sRNAs)

deep sequencing, 1077

role in host-fungal interactions, $\mathrm{S} 2.187$ role in the virulence of Xanthomonas

campestris pv. vesicatoria, S2.187

Smallwood, E. L., S2.15, S4.1

Smart, C., S2.141, S2.143, S2.190

Smart, C. D., S2.33, S2.37, S2.69, S2.76

Smartphone apps, to increase accuracy and early

detection of new or invasive diseases, S2.28

Smilax rotundifolia, $\mathrm{S} 2.165$

Smiley, R. W., 1130

Smith, A. M., S2.135

Smith, B. J., S2.97, S2.135

Smith, C. A., S2.27

Smith, C. M., S1.8

Smith, D., S2.9, S2.82, S2.112

Smith, D. L., S2.135

Smith, G., S2.69

Smith, H., S2.83, S2.84

Smith, J., S2.40, S2.120

Smith, J. A., S2.71

Smith, J. E., S2.48, S2.85

Smith, M., S1.2, S2.53

Smith, M. E., S2.58, S2.135, S2.150

Smith, R., S2.140

Smith, S., S1.3, S2.37, S2.48

Smith, S. M., S2.25

Smolinski, T., S2.114

Snelling, J., S2.64, S2.92

Snover-Clift, K. L., S2.136

Snow rot, $\mathrm{S} 2.65$

Soares, W. O., S2.112

Soby, S. D., S2.136

Soderlund, C., S2.44

Soft rot of onion, S2.173

Soft winter wheat

adult-plant resistance to Puccinia striiformis $\mathrm{f}$. sp. tritici, S2.97

effect of Fusarium head blight-Stagnospora leaf blotch management on yield and quality, S2.173

effect of QoIs on Fusarium head blight, S2.33

Sogatella furcifera, 509

Soilborne pathogens

effect of herbicides on, S2.84

hidden host plant associations with fungal pathogens, 538

percolation-based risk index for pathogen invasion, 1012

Soil management, effect on movement of

Salmonella enterica Typhimurium in tomato plants, 381

Soil management zones, use for application of

Telone in cotton, S1.5

Soil matric water potentials, regulatory effect on a tripartite host-specific rhizosphere interaction, S2.138

Soil microbes

for broad-spectrum mycotoxigenic fungi control in corn, $\mathrm{S} 2.166$

effects of agricultural management practices on, S2.162

in organic $v s$. conventional vegetable production, $\mathrm{S} 2.50$

response to organic and conventional fertilization, S3.4

Soil nematodes, assessment of diversity in soil samples, $\mathrm{S} 2.136$

Soil nitrate levels, effect on cotton production, S1.1

Soil RNA analyses, S2.50

Soil salinity. See Salinity

Solano, F., S2.136

Solanum bulbocastanum, $\mathrm{S} 1.3$

Solanum lycopersicon. See Tomato

Solanum phureja, 862

Solé, M., S2.13

Song, Q., S2.132

Sonti, R. V., S2.118

Sood, S., S2.29

Sooty blotch and flyspeck (SBFS)

diversity in apples in Spain, S2.12
Geastrumia polystigmatis, S2.88

phenology of infection on apple, S2.65 phylogenetic analysis, S2.66

Sooty mold, S2.19

Sopee, J., S2.26, S2.136

Sorghum (Sorghum bicolor)

response of lines differing at the $P$ locus to grain mold and head smut fungi, S3.3

screening germplasm for biotic and abiotic stress tolerance, $\mathrm{S} 2.11$

tolerance based index for screening accessions against stalk rot diseases, S3.2

Sorghum downy mildew, $\mathrm{S} 1.7$

Sosso, D., S2.167

Soto-Arias, J. P., S2.171

Soto-Plancarte, A., S2.136

Sour cherry (Prunus cerasus), characterization of

Plum pox virus isolates, 972

South American leaf blight (SALB), S2.61, S2.62

Southern blight, effects of agricultural

management practices on, S2.162

Southern corn rust epidemics, field evaluation of, S1.1

Southern rice black-streaked dwarf virus

(SRBSDV), 509

Souza, A. G., S2.100, S2.137

Souza, É. S. C., S2.112, S2.137

Souza, G. R., S2.91

Souza, P. E., S2.151

Souza, R. M., S2.91, S2.94

Soybean (Glycine max) aggressiveness and yield impact of Fusarium species, 822

biodiversity and potential pathogenicity of field collected oomycetes from asymptomatic plants, S2.28

Cercospora sojina mating-type distributions and genetic diversity, 1045

comparison of Fusarium tucumaniae and $F$. virguliforme isolates from, S2.163

cost to SMV for gain of virulence on $\mathrm{Rsvl}$ genotypes, $\mathrm{S} 2.73$

defense suppression by type III secretion system in Bradyrhizobiurm japonicum, S3.8

detection and differentiation of Colletotrichum species causing anthracnose, S2.164

effects of crop rotation on Pythium spp. population composition, S2.150

effects of fungicide and cultivar selection on seed quality with delayed harvest, S1.2 effects of minor elements on Cercospora leaf blight, S1.11, S2.158

effects of salinity on Pythium seed and rot roots, $\mathrm{S} 1.10$

efficacy of seed treatments on stand and yield in Arkansas, S1.9

evaluating for resistance to Phomopsis seed decay, S2.80

evaluation for resistance to charcoal rot, S2.130

factors affecting soybean cyst nematode syncytia location in roots, S2.143

field screening for Cercospora leaf blight resistance, S2.120

fungal diversity by plant section in

Mississippi, S2.146

fungicide resistance in Cercospora kikuchii, S2.116

fungicide sensitivity of Pythium species in Iowa, S3.6

genome expression in response to Fusarium virguliforme, $\mathrm{S} 2.117$

genotypic and phenotypic characterization of Fusarium oxysporum from roots, S2.39

global expression patterns of Xanthomonas axonopodis pv. glycines in leaves, S2.25

glyceollin in plant defense against Phytophthora sojae and Macrophomina phaseolina, 984 
identifying Meloidogyne incognita resistance in cultivars, S2.157

interactions with Fusarium oxysporum in seedling disease, $\mathrm{S} 2.31$

interactions with SMV and soil salinity, S2.76

interactive effects of Soybean mosaic virus and salt stress, S1.6

microbial and nematode communities in Nebraska soils, S2.83

molecular characterization of a novel soybeaninfecting nepovirus, S2.164

multi-state screen to identify seedling fungal pathogens, S2.158

oomycetes associated with seedling diseases, S2.123

oomycetes from isolates with damping-off, $\mathrm{S} 2.25$

pathogenicity of Diaporthe and Phomopsis, S2.89

pathogenicity of Pythium spp. at different

temperatures, S2.92

PCR-RFLP fingerprinting of Fusarium

oxysporum species complex, S2.40

potential use of non-native phytoalexins in controlling pathogens, S3.7

role of deoxynivalenol in seedling infections

by Fusarium graminearum, S2.21

role of Soybean mosaic virus-encoded

proteins in seed and aphid transmission, 941

sequencing approach to seed microflora

assessment, $\mathrm{S} 2.28$

temporal dynamics of root colonization by

Fusarium virguliforme, S2.157

VIGS study of proteins in soybean-

Phakospora pachyrhizi interaction, S1.4

Soybean aerial blight, precision concept for

management, S2.137

Soybean cyst nematodes

analysis of populations before and after corn rotation, $\mathrm{S} 3.7$

factors affecting syncytia location in soybean roots, $\mathrm{S} 2.143$

monitoring program and training system in

Puerto Rico, S3.17

in North Dakota, S2.107

virulence and diversity in Nebraska fields, $\mathrm{S} 3.3$

Soybean mosaic virus (SMV)

cost to SMV for gain of virulence on Rsvlgenotype soybeans, S2.73

interactions with soybeans and soil salinity, S2.76

interactive effects with salt stress on soybean, S1.6

role of SMV-encoded proteins in seed and aphid transmission, 941

Soybean root rot

effect of drainage systems on, S2.56

effects of salinity on, S1.10

Soybean rust

effects of frequency of "extreme" temperature highs on, 708

effects of mineral nutrition on, S2.133

efficacy of disinfestants in killing

urediniospores of, S3.2

See also Phakospora pachyrhizi

Soybean sudden death syndrome (SDS)

effect of flooding duration on the severity of, $\mathrm{S} 2.2$

See also Fusarium virguliforme

Soybean vein necrosis-associated virus ( $\mathrm{SVNaV})$, 966

Soybean vein necrosis disease (SVND),

epidemiology, 966

vectors and alternative hosts, $\mathrm{S} 1.11$

Soybean vein necrosis virus (SVNV), S2.135

Soybean viruses, occurrence and distribution in Oklahoma, S2.4
Sparassis, S2.113

Spatafora, J., S2.109, S2.137, S2.146

Spatial frailty modeling, in survival analysis of

cucurbit downy mildew epidemics, 216

Specialty crop clean plant centers, S2.179

Sphacelotheca reiliana, $\mathrm{S} 2.7$

Sphaeropsis pyriputrescens, S2.163

Sphaeropsis rot, sources and availability of

inoculum in apple orchards, S2.163

Sphingomonas, S2.46

Spiceland, D., S2.12

Spinach (Spinacia oleracea)

frequency of race 2 strains of Verticillium dahlia in seeds, $\mathrm{S} 2.133$

root colonization and internalization by $E$. coli O157:H7, 333

transfer of E. coli $\mathrm{O} 157: \mathrm{H} 7$ to by house flies, 373

Verticillium wilt, seed localization and efficacy of seed treatments, 268

Spinach downy mildew, examination of molecular

diversity with SSRs, S2.42

Spindle pole bodies, S2.93

Spinifex sericeus, S2.69

Spiroplasma citri, S2.157

Spiroplasma kunkelii, 129

Spring beauty (Claytonia virginica), S2.128

Spring dead spot of bermudagrass

impact of nitrogen source and $\mathrm{pH}$ on mycelial growth, S2.30

phylogenetic placement of fungi causing, $\mathrm{S} 2.44$

Springer, J. C., 1280

Spring wheat

association mapping of stripe rust resistance genes in germplasm lines, S2.155

evaluation of germplasm for resistance to tan spot, S3.1

evaluation of germplasm for tan spot

resistance, $\mathrm{S} 2.4$

QTL mapping of wheat stripe rust resistance, $\mathrm{S} 2.42$

Spurlock, T. N., S1.10, S2.42, S2.137

Squash vein yellowing virus (SqVYV), 1243

Squires, J. N., S2.39

Srinivasan, R., S2.137

Srivastava, S., S2.28, S2.30

Srour, A., S2.101, S2.158

Stack, J., S2.99

Stack, J. P., S2.98, S3.4, S3.8

Stagonospora leaf blotch (SLB), S2.173

Stagonospora nodorum, S2.95

Stagonospora nodorum blotch, effect of levels of wheat residue on severity of, S2.95

Stajich, J., S2.53, S2.137

Stalker, H. T., S2.183

Stalk rot diseases, tolerance based index for

screening sorghum accessions against, S3.2

Stall, R. E., S2.131

Stamler, R., S2.138

Standish, J., S2.146

Stanghellini, M., S2.138

Stanosz, G. R., S2.116

Starr, J. L., S1.2

Steadman, J., S2.138, S3.9

Steaming, to eradicate Phytophthora ramorum

from nursery soil, S2.129

Steen, C., S2.150

Steenkamp, E., 400

Steffenson, B., 600, S3.2

Stefkova, K., S2.71

Steger, A., S1.2, S1.9, S2.80

Steger, A. J., S2.150

Steinberger, Y., S2.136

Stem blight of blueberry, S2.119

Stem dieback of tropical trees, S2.122

Stem diseases of lowbush blueberry, S2.7

STEM experiences, S2.33

Stenger, D. C., 117, S2.78

Stenocarpella maydis, S2.123
Stenroos, S., S2.96

Stensvand, A., 717, S2.10, S2.14

Stern, R. F., S2.113

Sterol demethylation inhibiting fungicides,

sensitivity of Cercospora beticola to, $\mathrm{S} 2.21$

Stetina, T. J., S1.10

Stevenson, K. L., S1.4, S2.43

Stevenson, W. R., S2.136

Stewart, B., S2.153

Stewart, B. R., S1.10

Stewart, C. L., S2.138

Stewart, D., S2.76

Stewart, J. E., 741, S2.123, S2.139

Stewart, M., S1.2

Stewart's wilt of corn

resistance in dent corn inbreds, S2.17

trend study in the U.S., 2001-2012, S3.3

stfC gene, 362

Stidham, M., S2.51

Stielow, B., S2.16

Stilbene synthase genes, S2.32

Stipanovic, R. D., S2.31

Stobbe, A., S2.33, S2.139, S2.176

Stodart, B. J., S2.10

Stojšin, V., S2.21, S2.102

Stokes, C. E., S1.10, S2.139

Stomata, effect of JAZ on pathogen entry, S2.105

Stomatal immunity, 326

Stone, A., S2.124

Stone, E. A., S1.8

Stone fruit trees, surveying for viruses in Texas, S2.49

Stoner, A., S1.3

Stored grain diseases and pests, strategies for sampling and mitigation, S2.59

Stover, E., 15, S2.118

Strausbaugh, C. A., S2.139

Strauss, A., S2.131

Strauss, S. L., S2.92, S2.140

Strawberry (Fragaria $\times$ ananassa)

black root rot management, S2.147

characterization of Podosphaera aphanis infection, S2.10

effect of biological control agents on leaf microbiota, 1001

enhancement of Colletotrichum

gloeosporioides resistance, S2.134

evaluation of fungicide applications for control of Botrytis and anthracnose, S2.112

factors affecting foliar mildew severity in, 811,1087

fungi associated with diseased roots of runner plants, S2.95

LAMP assay for detection of Colletotrichum acutatum, S2.166

microbial suppression of soilborne diseases, S2.85

monitoring for fungicide resistance in Botrytis cinerea, $\mathrm{S} 2.43$

monitoring Xanthomonas fragariae infection process, $\mathrm{S} 2.155$

salicylic acid-mediated defense network, S 2.82

screening germplasm for anthracnose disease resistance, $\mathrm{S} 2.97$

temperature regulation of chasmothecia initiation in powdery mildew of strawberry, 717

virus outbreak in Nova Scotia nurseries, S2.90

Strawberry black root rot, S2.147

Straw bio-reactor, S2.83

Strayer, A., S2.141

Stream ecosystems, isolation of Pythium and

Phytophthora from, S4.2

Street trees, bacterial leaf scorch in Washington

D. C., S4.2

Strelkov, S. E., 1052

Streptomyces humidus, 23 
Streptomyces scabies

biological control by Pseudomonas sp.

LBUM223, 995

effect of pathogen variation and urea on biological control of, 34

regulatory genes affecting thaxtomin

production and pathogenesis in, S2.77

thaxtomin induction and regulation by, $\mathrm{S} 2.45$

Streptomycin, sensitivity of Erwinia amylovora to, $\mathrm{S} 2.70$

Streubel, J., S2.170

Striatin-interacting protein, S2.167

Strickland, T. C., S1.8

Stringfellow, W., S2.39

Stripe rust

association mapping of resistance genes in spring wheat germplasm lines, S2.155 early monitoring based on infrared spectroscopy, S2.80

epidemics of wheat and barley and races of Puccinia striiformis identified in the U.S. in 2012, S2.155

population structure and genomics, S2.184

predicting epidemics using general estimation equations, S3.4

Strobel, G. A., S2.79

Strohmeier, S., 1001

Stromberg, V. K., 237

Stubbs, J., S2.74

Stulberg, M. J., S2.140

Sturrock, R. N., 583

Stutz, J. C., S2.140

Suarez, S. N., S2.109

Subbarao, K. V., 268, S2.54, S2.133

Šubr, Z., 972

Succinate dehydrogenase inhibitor (SDHI)

resistance, review of current knowledge, 880

Sudarshana, M. R., 1069, S2.4, S2.140

Sudarshana, P., S2.140

Sudden death syndrome (SDS), S2.117 See also Soybean sudden death syndrome

Sudden oak death, S2.32

See also Phytophthora ramorum

Suding, K., S2.60, S2.146

Sudini, H. K., S2.66, S2.141

Suga, H., 400

Sugar beet (Beta vulgaris)

curly top management, S2.139

Fusarium stalk blight and rot, S2.56

identification of Cercospora-resistant lines, S2.128

management of Rhizoctonia solani, S2.73

Sugar beet curly top management, S2.139

Sugar beet leaf spot (CLS), S2.21

Sugarcane

evaluating for resistance against Xanthomonas albilineans, S2.54

genetic diversity of viruses causing mosaic in, S2.158

history of brown rust in Florida, S2.29

introduction of orange rust in Louisiana, S2.53

loop-mediated isothermal amplification for detection of Leifsonia xyli subsp. xyli, S2.84 variability in Puccinia melanocephala pathogenicity and cultivar resistance, S2.10

Sugarcane wilt, S2.134

Su, H., S2.79

Suhr, M., S2.55

Suillus, S2.82

Sultana, V., S2.18, S2.38

Sulyok, M., S2.175

Summerell, B. A., 400

Summers, C., S2.141

Sun, B.-J., 949

Sundaresan, V., S2.187

Sundin, G. W., 304, S2.2, S2.79, S2.191

Sun, F., S2.184
Sunflower (Helianthus annuus)

characterizing aggressiveness of Phompsis stem canker, S2.91

identification of sources of resistance to

Plasmopara halstedii, S2.63

Sunil Kumar, G. B., 1260

Sun, L.-Y., 949

Sun, M., S2.83

Sun, S., S2.80

Sun, W., S2.184

Sun, X., S2.141

Superstorm Sandy, S2.99

Surface irrigation water, ultraviolet treatment, S2.69

Surface plasmon resonance technology, S2.167

Surfactin, S2.98

Susca, A., S2.175

Suslow, K., S2.129

Suslow, T., 341

Sutton, B., S2.141

Sutton, D. A., 400

Su, Y., 1162

Suzuki, H., S2.180

Svendsen, J., S2.12

Swain, S., S2.142

Swainsonine, S2.12

Swart, F., 281

Swartwood Towne, M., S2.136

Sweany, R. R., S2.142

Sweet cherry, viruses associated with rusty mottle and twisted leaf diseases, 1287

Sweet orange, stability in Citrus tristeza virus

populations in field and glasshouse, S2.31

Sweet orange scab, S2.30

Sweet potato (Ipomoea batatas)

biodiversity of the fungal community present in, S2.139

diversity of fungal and bacterial communities in tip/end rot, S1.10

effect of viruses and water-stress on storage root initiation, $\mathrm{S} 2.142$

microbial disease complex of tip/end rot, S2.139

Sweet potato viruses, detection, S2.5, S2.76,

S2.109

Sweets, L., S2.123

Sweigard, J., S2.51

Swett, C. L., S2.191

Swietenia, S2.136

Switchgrass (Panicum virgatum)

characterization of culturable bacterial endophytes, S2.163

development of biopesticide extractives against bacterial spot of tomato, S2.109

eight new viruses identified in, S2.3

foliar disease incidence associated with in

Mississippi, S2.49

Panicum mosaic virus as a potential threat,

S2.138

in silico identification and characterization of

NB-LRR-encoding resistance genes, S2.46

Swoboda, G. A., S2.55, S2.142, S2.165

Sybren De Hoog, G., 400

SYBR green qRT-PCR, detection of High plains virus, S2.9

Sylla, J., 1001

Sylvain, I. A., S2.49

Symptomatic hosts, 538

Symptomless plant symbioses, S2.185

Synanthropic flies, S2.185

Syringomycin E, S2.72

Systemic Acquired Resistance inducers, trunk

injection, S2.2

Szabo, L., S2.164

Szarkándi, G. J., S2.142

Szostek, S., S2.142

Szurek, B., S2.13, S2.170

Tabima, J. F., S2.70

Takach, J. E., S2.142, S2.165
Takahashi, Y., 575

Takano, Y., 733

Takemoto, J., S2.72

Takeshita, M., 960

Talbot, J. M., S2.181, S2.182

Talbot, J. W., S2.82

TAL effectors. See Transcription Activation-Like effectors

Talley, J., 373, S2.185

Tall fescue (Lolium arundinaceum) additional hosts of Balansia epichloe, S2.11 effect of endophyte on plants under drought stress, S2.101

effect of mowing height on establishment, S3.9 endophyte utilization, quality assurance, and characterization, S2.142

Tally, A., S2.106

Tamborindeguy, C., S2.79

Tamir-Ariel, D., 362

Tan, C. C., S2.78

Tancos, M., S2.143

Tang, J. L., S2.170

Tanguay, P., S2.76, S2.143

Tang, W., S2.170

Tang, Y., S2.92

Tanney, J., S2.103

Tan spot

evaluation of spring wheat germplasm for resistance, S2.4, S3.1

lipid profiles in wheat cultivars resistant and susceptible to, 74

Tao, A., S2.81

Taqman real-time PCR

detection of Gooseberry vein banding associated virus, S2.156

detection of grape crown gall, S2.69 detection of High plains virus, S2.9

Targeted genome editing, identification of new rice resistance genes, $\mathrm{S} 2.13$

Target spot of cotton, S2.54

Tariq, S., S2.18

Taski-Ajdukovic, K., S2.21

Tassel fungicide applications, impact on the Aspergillus and Fusarium spp. mycoflora of harvested corn, $\mathrm{S} 1.1$

Tatalovic, N., S2.143

Tatineni, S., S2.143

Tauxe, R., 306

Taylor, A., S2.104

Taylor, C. G., S2.155

Taylor, D. L., S2.60

Taylor, J., S2.82, S2.182

Taylor, J. W., S2.49, S2.186

Taylor, L., S2.182

Taylor, T., S2.67

Taylor, T. N., S2.180

Teale, S. A., S2.23

te Beest, D. E., 666

Tebeest, D. O., S1.10

Techniques

detection and quantification of Leveillula taurica growth in pepper leaves, 623

gene knockout in Setosphaeria turcica using Agrobacterium tumefaciens-mediated transformation, 641

magnetic capture hybridization real-time PCR assay for detecting Agrobacterium vitis, 633

Teixeira, G. A., S2.143

Télef-Micouleau, N., 1028

Telle, S., S2.178, S2.179

Telone, S1.5

Temperature

effects of frequency of "extreme" temperature highs on soybean rust development, 708 regulation of chasmothecia initiation in powdery mildew of strawberry, 717

Temperature/wetness modeling, of pseudothecium maturation and ascospore release in Guignardia citricarpa, 281 
Temple, K., S2.73

Temple, T. N., S2.150

Temporary ponds, $\mathrm{S} 2.34$

Tennant, P., S2.123

Tenuivirus, 513

Tenuta, M., S2.98

Teosinte, expression profiling and evolution of

pathogenesis related genes in response to

Ustilago maydis, $\mathrm{S} 2.25$

Teplitski, M., 316, 352, S2.12

tepR, $\mathrm{S} 1.8$

Terán, H., S3.17

Teratosphaeriaceae phylogeny, S2.16

Testen, A., S2.144, S2.191

Teunissen, H. A. S., S2.94

Texas Phoenix Palm Decline (TPPD), S2.177

Texas root rot (TRR), S1.7

Thapa, S., S2.144

Thaxtomin, S2.45, S2.77

Thelonectria, S2.125

Thermophilic fungi, S2.64, S2.126

Thiamethoxam, in control of citrus canker, S2.52

Thiers, B., S2.97, S2.144

Thies, J., S2.144

Thiessen, L. D., S2.144

Thines, M., S2.178, S2.179

Thiophanate-methyl, S2.52

Thioredoxin family protein, S2.69

Thomas, A., S2.145

Thomas, A. L., S2.72

Thomas, C., S3.13

Thomas, E., S2.144

Thomas, K. A., 741

Thomas, S., S2.59, S2.136, S2.140, S2.145, S3.4, S3.8

Thomas, V. P., 935

Thompkins, A., S2.120

Thompson, C., S3.9

Thompson, J., S2.145

Thompson, J. R., S2.145

Thompson, S., S2.69

Thousand cankers disease, S2.120, S2.163

Thrane, U., 400

Thrips, transmission of Salmonella enterica,

S2.171

Thrips tabaci, S2.142

Thurber, C., S2.24

Tian, L., S2.132

Ticosynnema gen. nov., S2.52

Tilletia caries, $\mathrm{S} 2.93$

Tilletia indica, $\mathrm{S} 2.73$

Tillier, E., S2.180

Tillman, B. L., S1.9

Timer, J., S2.58

Timilsina, S., S2.146

Timling, I., S2.182

Timmer, L. M., 74

Tip/end rot of sweet potato, S1.10, S2.139

Tisserat, N., S2.64, S2.65, S2.87

Titanium dioxide formulations, 228

TmpL protein homolog, S4.1

Tobacco

CHP-7 in leaf apoplast, S2.87

comparing the effects of Xylella fastidiosa subspp. multiplex and fastidiosa, S2.107

Tobacco black shank, 610

Tobacco mosaic virus (TMV)

assessing vacuole trafficking and metabolizing components for their influence on, S2.189

development of end-point multiplex RT-PCR and helicase dependent amplification for the identification of, S2.9

Tobacco necrosis virus (TNV), S2.43

Tobamovirus-induced disease, assessing vacuole trafficking and metabolizing components for their influence on, $\mathrm{S} 2.189$

Tobias, T., S2.64, S2.115, S2.126, S2.146, S2.149

Tobutt, K. R., S2.75
Todd, C. E., S2.146

TofI/TofR quorum sensing system, S1.2

Tohamy, A. M. M., S2.39

Toledo, L. F., S2.15, S2.67

Tollefson, S. J., S3.16

Tomaso-Peterson, M., S1.4, S1.10, S2.49, S2.146, $\mathrm{S} 2.153$

Tomato (Solanum lycopersicon)

Alternaria stem canker, 733

combined control of late blight, early blight, and Septoria leaf spot, S2.101

consequences of disrupting Salmonella AI-2 signaling on interactions with soft rots, 352 effect of application of Ascophyllum extract on growth, disease incidence, and yield, S3.11 effect of plant nitrogen nutrition on Botrytis cinerea secondary inoculum, 261 effect of soil management on movement of Salmonella enterica Typhimurium in, 381 effect of transitional organic production practices on soilborne pests, 792 eicosapolyenoic fatty acids induce resistance to Phytophthora capsici, S2.122 evaluating rootstocks for bacterial wilt resistance, $\mathrm{S} 2.134$

evaluation of an antagonistic rhizosphere fungal consortium against Fusarium oxysporum f. sp. lycopersici, S2.9

factors affecting proliferation of Salmonella enterica, $\mathrm{S} 2.12$

fruit colonization by Clavibacter michiganensis subsp. michiganensis, S2.143 fungal and oomycete pathogen detection in the rhizosphere of organic tomatoes, S2.141 genetic transformation with a calcium signal modifier gene, S2.86

identifying host targets for Ralstonia solanacearum type III effectors, S2.73

implications of Tomato yellow leaf curl virus resistance for virus epidemics and management, S2.137

late blight resistance in heirloom and hybrid cultivars, S2.129

molecular diagnosis of bacterial spot pathogens, S2.74

occurrence and distribution of pathogenic and indicator bacteria, $\mathrm{S} 2.89$

rhizobiome responses to new tomato rootstock systems, S3.8

vaccination with a lab-attenuated strain of Pepino mosaic virus, $\mathrm{S} 2.26$

viral infections in Ghana, S2.12

weeds as potential inoculum sources for begomoviruses, 436

Tomato apical stunt viroid (TASVd), S2.12

Tomato early blight, management, S2.101, S2.118

Tomato late blight

effect of an open-ended high tunnel production system on, S3.15 management, S2.101, S2.134 resistance in heirloom and hybrid tomatoes, $\mathrm{S} 2.129$

Tomato necrotic dwarf virus (ToNDV), S2.160

Tomato ringspot virus (TRSV), S2.49

Tomato rootstock systems, rhizobiome responses to new systems, $\mathrm{S} 3.8$

Tomato severe rugose virus (ToSRV), 436

Tomato sour rot management, S2.173

Tomato spotted wilt virus (TSWV)

development of end-point multiplex RT-PCR and helicase dependent amplification for the identification of, S2.9

evaluation and relative susceptibility of lettuce varieties to, S3.17

identification of Frankliniella occidentalis proteins that interact with, S3.2

inhibition of vector transmission, S3.7

Tomato wilt. See Ralstonia solanacearum

Tomato yellow leaf curl disease (TYLCD), S2.4
Tomato yellow leaf curl virus resistance, S2.137

Tombusviruses, 501, S2.105

Tomlinson, A., S2.101

Tompkins, D., S2.95

TonB-dependent receptors (TBDTs), S2.170

Tonnessen, B. W., S2.89

Tonoplast intrinsic protein 2 (TIP2), 175

Toomajian, C. P., S2.98

Toome, M., S2.146

Toperek, S., S2.35

Toprak-Celebi, F., S2.145

Torradovirus complex, S2.94

Torres-Barragan, A., S2.147

Tosa, Y., 575

Tospoviruses

emergence and impact in Florida, S2.158

fine structure mapping of silencing suppressor activity in, S2.110

interaction between proteins in mixed infections, S2.148

threat to vegetable production in Puerto Rico, S3.13

Toth, I. K., 333

Tournas, V. H., S2.147

Toussaint, V., S2.147

Toves, P. J., S2.6

Towata, T., 509

Toxoflavin, S1.8, S2.192

Toyoda, H., 623

Trail, F., 400, S2.117

Trainum-P, 1001

Trammell, L. L., S2.142

Trammell, M. A., S2.142

Tran, P., S2.147

Transcription Activation-Like (TAL) effectors contribution of typeIII/TAL effectors to pathogenicity, S2.170

convergence on a single host susceptibility gene in citrus canker, S2.62

diverse plant genes targeted by, S2.167

diversity and adaptation in Xanthomonas populations, S2.171 effect of temperature on expression of TAL effector-activated rice genes, S2.30 in Xanthomonas citri, S2.131

Transformation. See Genetic transformation

Transgenic rice, Rice grassy stunt virus resistance induced in, 513

Transitional organic production practices, effect on tomato soilborne pests, 792

Transmission electron microscopy (TEM), visualization of 'Candidatus Liberibacter asiaticus' cells in citrus seed coat vascular bundles, 545

Tran, T. M., S2.147

Tran, T. T., S2.170

Trappe, J., S2.58

Travadon, R., S2.13, S2.148

Tredway, L., S2.14, S2.116, S4.1

Tree fruit viruses, characterization by next generation sequencing, S2.124

Tree nuts fungal contaminants recovered from, S2.147 use of PCR in speciation of fungi recovered from, S2.147 See also Specific tree nuts

Tree of Life, S2.48

Trejo, R., S2.57

Trent, M. A., S2.21

Tresch, N., S2.77

Treseder, K., S2.64, S2.183

Trialeurodes vaporariorum, S2.7

Triazole fungicides, S2.127

Trichoderma harzianum T22, 1001

Trichoderma harzianum T39, 1227

Trichoderma spp. in the control of Botryosphaeria dieback in grapevine, $\mathrm{S} 2.103$ control of soilborne pathogens with, S2.42 
effect of volatile organic compounds on Arabidopsis thaliana, S2.63 responses in plants to volatile organic compounds from different species, S2.78

Trichoderma virens, S2.99

Trichodorus obtusus, S2.131

Trichomycetes, S2.13

Trichothecenes, 682

Trick, H. N., S3.9

Trifolium incarnatum, S2.60, S4.2

Trigiano, R., S2.54

Tringe, S., S2.182

Trinh, S. A., S2.94

Tripathi, D., S2.148

Triple Gene Block (TGB) proteins, S2.188

Triplett, L., S2.10, S2.92, S2.148

Triterpene saponins, S1.9, S2.121

Triticale, evaluation for Xanthomonas translucens

pv. undulosa resistance, S2.127

Triticum aestivum. See Wheat

Triticum durum, evaluation of germplasm for

resistance to Puccinia triticina, S3.2

Triticum mosaic virus (TriMV), S2.143

Trivedi, P., 652, S2.80

Trivellas, A., S2.51

Tronsmo, A. M., 717, S2.10, S2.14

Tropical forests/trees

diversity and evolutionary relationships of bacteria associated with seeds and seedassociated fungi, S2.48

host specificity of fungal phyllosphere communities, S2.13

Tropical plant pathology, teaching to a global

audience, S2.189

Trouvelot, S., 1035

Trowbridge, S. M., S2.36

Trumble, J., S2.72

Trunk injection in control of apple scab, S2.2 in control of fire blight, S2.2

Truong, C., S2.149

Tsai, Y., S1.10

Tsai, Y. C., S2.149

Tsai, Y.-L., 888

Tsuchiya, K., 960

Tsui, C., S2.143

Tsukahara, R. Y., S3.3

Tsukamoto, S., S2.174

Tuber lyonii (pecan truffle), S1.2, S2.135

Tugume, A. K., 949

Tulane virus (TV), 389

Tulloss, R. E., S2.63

Tunali, B., S4.1

Turechek, W., 1243, S2.155

Turfgrasses

development of SCAR markers and UP-PCR cross-hybridization method for detection of brown patch, $\mathrm{S} 2.76$

new occurrences of rapid blight and other labyrinthulids, S2.107

silver nanoparticles as a novel nematicide, S1.2

See also Individual grasses

Turgeon, B. G., 641

Turini, T. A., S3.17

Turnip mosaic virus (TuMV)

artificial microRNA-mediated resistance, 870

host membrane recruitment for replication and intercellular movement, S2.188

Tuskan, G., S2.18

Tuter, J., S2.115, S2.149

Twisted leaf of sweet cherry, 1287

Twitching motility

virulence in Ralstonia solanacearum P673 and, S2.17

in Xylella fastidiosa, S2.32

Twomey, M., S2.161

Tychon, B., S2.38

Tylka, G. L., S2.107, S2.143, S2.174
Tymon, L., S2.149, S3.17

Type III effectors (T3Es), S2.170

Type III secretion system (T3SS)

activation in Ralstonia solanacearum, S2.32 in Bradyrhizobiurm japonicum, S3.8 in Pantoea stewartii, S2.171

Type VI secretion system, virulence in Ralstonia solanacearum P673 and, S2.17

Tzanetakis, I. E., 966, S1.3, S1.6, S1.11, S2.87

Tzean, S. S., S2.28

Tzs protein, 888

Uchida, J. Y., S2.123

Udayanga, D., S2.150

Uddin, W., S2.81, S2.117

Udvardi, M., S2.92

Uehara-Ichiki, T., 513

Uehling, J., S2.58, S2.150

Ullrich, S. E., S2.3

Ultradwarf bermudagrass characterization of ectotrophic root-infecting fungi, S2.153 ectotrophic root-infecting fungi, S1.10

Ultraviolet treatment control of powdery mildew under greenhouse conditions, S2.9 of surface irrigation water, S2.69

Umeda, K., S2.3

Undergraduate biology curriculum, integrating foundational topics in, S2.160

Undifilum, S2.12

University of Illinois maize inbred collection, S3.6

University of Michigan Herbarium, S2.45

Upadhyaya, H. D., S2.141

Uppala, S. S., S2.150

UP-PCR cross-hybridization method, S2.76

Úrbez-Torres, J. R., S2.148

Urbina, H., S2.150

Urea, influence on Streptomyces antagonists, 34

U'Ren, J. M., S2.26, S2.150, S2.161

Uribe-Cortes, T. B., S2.134

Uribe-Vélez, D., S2.17, S2.85

Uridine diphosphate-glycosyltransferase, 682

Uromyces appendiculatus, S2.132

Uromyces transversalis resistance, $\mathrm{S} 2.151$

Urrea, K. E., S2.150

Usnea, S2.149

Ustilaginoidea virens, S1.10, S2.184

Ustilaginoidins, S2.184

Ustilago maydis

aflatoxin and fumonisin contamination of corn, S2.176

expression profiling and evolution of maize pathogenesis related genes in response to, S2.25

transcription factors in pathogenesis and meiosis, $\mathrm{S} 2.26$

Ustiloxins, S2.184

UV-B radiation. See Ultraviolet treatment

Uyemoto, J. K., 1069, S2.4

Vacas, J. G., 555

Vacuolar Processing Enzyme (VPE), S2.189

Vágvölgyi, C., S2.142

Vahling-Armstrong, C. M., S2.8, S2.37

Vaira, A. M., S2.188

Valdés, I., S2.122, S2.151

Valdes, S., S2.43

Valdez-Balero, A., S2.134

Valencia-Botín, A. J., S2.151

Valencia peanut

carbon sources in relation to pathogenicity of Sclerotinia sclerotinia, S3.14 evaluation of biorational products for efficacy against fungal pathogens, S3.16

Valent, B., S2.186

Valenzuela-Solano, C., S2.99, S2.103

Vallad, G. E., 228, 381, S2.146
Valverde, R., S1.5, S1.6, S2.2, S2.59, S2.73

Van Bockstaele, E., 1169

Van Bruggen, A. H., 381, S2.40, S2.46, S3.9

Vance, V., S2.187

van de Lee, T., 1169

van den Berg, F., 1209

van den Bosch, F., 666, 690, 1209

Van der Heyden, H., 811, 1087

Vandervoort, C., S2.2

Van Deynze, A., S2.101

Van Diepeningen, A., 400

Vandruff, S. M., S2.151

Van Eck, L., S2.87

VanEtten, H. D., 255, 400

Van Ghelder, C., 833

VanOverbeke, M., S2.52

VanWoerkom, A. H., S2.2

Varga, C., S2.151

Vargas, A., S2.114

Vargas-Ayala, R., S3.17

Vargas, J., S2.145

Varshney, R. K., S2.183

Vasco, G. B., S2.151

Vasilyeva, L., S2.151

Vaughan, R. H., 146

Vaz, A. B., S2.113

Vazquez, G., S2.91

Vazquez, O., S2.152

Vazquez, S., S2.92

Vega, B., S2.152

Vegetative compatibility, in Cryphonectria parasitica, 1280

Vegetatively-propagated crops estimating the effectiveness of strategies to reduce seed degeneration in, S2.145 evaluation of management strategies to reduce seed degeneration in, S3.8

Velázquez, K., 1077

Velazquez-Liano, L. R., S2.152

Velazquez-Monreal, J. J., S2.15

Velez, P., S2.152

Vellinga, E. C., S2.70

Venkatesan, V., S2.104

Ventura, J. A., S2.113

Venturia inaequalis

control with foliar applications of phosphite fungicide, S2.39

control with trunk injection in apple, S2.2

CYP51A1 upstream anomalies in myclobutanil and difenoconzaole resistant isolates, S2.153

leaf-shredding as a component of integrated management for, S2.154

molecular characterization, S2.75

winter pseudothecial and ascal densities in South Africa, S2.154 See also Apple scab

Vera-Cruz, C., S2.19, S2.76, S2.152

Verdier, V., S2.10, S2.19, S2.30, S2.76, S2.152,

S2.170

Verma, R., S2.176

Verticillium dahliae

comparison of real-time PCR protocols for the monitoring of asymptomatic infections on olive, 1058

effect of green manure crops on, S2.98

effect on cotton production, $\mathrm{S} 1.1$

genetic differentiation between populations

from asymptomatic and symptomatic hosts, S2.68

genetic structure of populations from mint and potato, 445

hidden host plant associations, 538

histology and transcriptional changes in corn seed infected by, S2.133

incidence and impact in soil associated with certified potato seed, 55

peduncular infection and seed transmission in chile pepper, S3.14 
population genetic analysis from lettuce, S2.54 race 2 strains in spinach seed, S2.133 in soil, roots, and stems of green manure crops, S2.159

on spinach, seed localization and efficacy of seed treatments, 268

See also Potato early dying

Verticillium spp., biocontrol agents to control in chile pepper, $\mathrm{S} 2.56$

Verticillium wilt

biocontrol agents in chile pepper, S2.56

effect on cotton fiber quality, S2.161

genetic structure of populations from mint and potato, 445

incidence and impact in soil associated with certified potato seed, 55

on olive, comparison of real-time PCR assays monitoring asymptomatic infections, 1058 seed localization and efficacy of seed treatments in spinach, 268

Veterano, S. T., S2.28

Viana de Sousa, M., S2.153

Vicia villosa, S2.60, S4.2

Vico, I., S2.70

Vidalakis, G., S2.156

Videira, S. I. R., S2.153

Vilchez, M., S2.3

Vilgalys, R., S1.2, S2.14, S2.18, S2.53, S2.82,

S2.135, S2.150, S2.160, S2.182

Viljoen, A., 400, S2.72

Villamor, D. E. V., 1287

Villani, S., S2.153

Villegas, V., S2.17

Villordon, A. O., S2.142

Villosiclava virens, $\mathrm{S} 2.184$

Viloria, Z., S2.86

Vincelli, P., S2.6

Vines, P. L., S1.10, S2.153

Viral watermelon vine decline, 1243

Virginia Marano, A. V., S2.153

Virola PGPR extracts, S2.14

Virology

artificial microRNA-mediated resistance in mixed infections, 870

association of a DNA virus with grapevine red blotch disease, 1069

bioinformatic pipeline for use in metagenomic virus discovery, S2.139

characterization of sour cherry isolates of Plum pox virus, 972

dynamics of Southern rice black-streaked

dwarf virus in rice, 509

epidemiology of Soybean vein necrosis-

associated virus, 966

factors driving the expanding distributions of, S2.179

genetic diversity and potential vectors and reservoirs of Cucurbit aphid-borne yellows virus, 1188

genetic variability, evolution, and biological effects of Grapevine fanleaf virus satellite RNAs, 1180

genetic variation in wheat streak mosaic virus, 98

genome sequence and biological characteri-

zation of Moroccan pepper virus, 501

induction of antiviral responses against Cucurbit chlorotic yellows virus in melon, 960

intracellular accumulation and movement as a target for disease control, S2.188

Little cherry virus 1, genome characterization and association with Shirofugen stunt disease, 293

new enamovirus associated with Citrus vein enation, 1077

a novel virus of the genus Cilevirus, 488

reclassification of Lettuce necrotic stunt virus, 501
Rice grassy stunt virus resistance induced in transgenic rice, 513

role of siRNAs in infections of maize, S2.187

role of Soybean mosaic virus-encoded

proteins in seed and aphid transmission, 941

selection pressure and founder effects in

Wheat yellow mosaic virus, 949

transformative technologies from knowledge

of virus-aphid vector interactions, S3.2

viruses associated with rusty mottle and

twisted leaf diseases of sweet cherry, 1287 See also Individual viruses

Virulence factors, CsrA positive regulation of virulence factors in Erwinia amylovora, S2.6

Virulence genes, effects of Tzs protein and exogenous cytokinin on expression in $A$. tumefaciens, 888

Virus-induced gene silencing (VIGS), S1.4

Virus resistance, in somatic fusions and crosses of

Solanum bulbocastanum and S. tuberosum, S1.3

Visser, R. G. F., 623

Vitale, S., 802

Viteri, D., S3.17

Vitis labrusca, S2.58

Vitis rotundifolia, effects of fungicide applications on, S2.135

Vitis vinifera. See Grapevine

Vitoreli, A., S2.153

Vivanco, C. E., S2.12, S2.108

Vives, M. C., 1077

Vlasák, J., S2.96

Vodak, M., S2.51

Vogel, K., S2.138

Voisin, R., 833

Vojnov, A. A., 555

Volatile organic compounds (VOCs) identifying wheat pathogens through, S2.43 responses of plants to VOCs from species of Trichoderma, S2.63, S2.78

Von Diest, S. G., S2.154

von Einem, S., S2.70

von Tiedemann, A., 682

Vorsa, N., S2.114

Vowell, T. K. S., S2.6

Vu, A. L., S2.109

Vyas, M., S2.44

Waalwijk, C., 400

Wadl, P., S2.54

Wai, C. M., S2.119

Waldenmaier, C., S2.120

Walenta, D. L., S2.37

Waliyar, F., S2.104

Walker, A. M., S2.140

Walker, C., 1130

Walker, D., S2.182

Walker, D. R., S1.4

Walker, N., S2.44, S2.112

Walker, N. R., S2.52

Wallingford, A. K., S2.154

Wallis, C. M., S2.154

Walnut, management of lesion and ring nematode, S2.159

Walnut twig beetle (Pityophthorus juglandis),

S2.120

Walsh, C. S., S2.89

Walsh, E., S2.155

Wamishe, Y., S2.24

Wan, A., S2.155, S2.156

Wang, D., S2.155, S2.164, S2.165

Wang, F., S2.89

Wang, G. L., S2.24

Wang, H., S2.155, S2.189

Wang, H. G., S2.80

Wang, J., 594, 1162, S2.156, S2.157

Wang, L., 927, S2.171

Wang, M., S2.42, S2.155, S2.156, S2.187

Wang, N., 652, S2.50, S2.62, S2.67, S2.80,

S2.119, S2.157, S2.167, S2.168
Wang, N. Y., S2.156

Wang, R., S2.78

Wang, S., S2.155

Wang, W., 641

Wang, X., S2.105, S2.157, S2.184

Wang, Z. Y, 927

Wan, Q., S2.81

Ward, A., S2.157

Ward, B. M., S1.11, S2.133, S2.158

Ward, T. J., 400

Warner, A. J., S2.158

Warnke, K. Z., S2.158

Warnstrom, E. L., S2.158

Warren, J., S2.158

Wasala, L., 373

Washington-Keizerweerd, A. T., S2.158

Watermelon (Citrullus lanatus)

Ceratobasidium root rot, S2.103

effect of cover crops on root arbusuclar mycorrhizal colonization, S4.2 general suppression of Fusarium wilt with cover crops, S2.60

latent class analysis estimation of diagnostic tests for Squash vein yellowing virus, 1243 management of pre- and post-harvest Phytophthora fruit rot, S1.6

Wayadande, A., 129, 373, S2.7, S2.9, S2.185

Weather-driven logistic regression models,

predicting Fusarium head blight epidemics, 906

Weaver, M., S2.158

Weaver, M. A., S2.68, S2.176

Web blight, S2.30, S2.91

Webb, S. L., S2.92

Webster, C., S3.13

Webster, C. B., 1243

Webster, C. G., S2.158

Wechter, W. P., S2.32

Weeds, as potential inoculum sources for a tomato-infecting begomovirus, 436

Weeping willow, Melampsora rusts, S2.146

Wegulo, S. N., S2.143

Wei, A., S2.140

Weiberg, A., S2.187

Weiß, M., S2.64

Wei, G., 488, S2.109, S2.113, S2.124

Weigle, T., S2.58

Wei, H. H., S2.83, S2.84

Wei, L., S2.159

Weiland, J., S2.159

Welser, M. J., S2.161

Welti, R., 74

Wen, A., S2.69, S2.159

Wenninger, E. J., S2.102, S2.139

Wen, R. H., S2.73

Wessel-Beaver, L., S3.16

Westerdahl, B. B., S2.159

Westerhof, J., S2.94

West, J. L., S2.23

Westmoreland, M., S2.20

Wharton, P. S., S2.96, S2.161

Wheat (Triticum aestivum)

adult-plant resistance to Puccinia striiformis $\mathrm{f}$. sp. tritici, S2.97

association mapping of stripe rust resistance genes in spring wheat germplasm lines, S2.155

characterization and quantification of

Fusarium spp. on roots, S2.83

determination of 2,4-DAPG and phenazineproducing Pseudomonas spp. in, S2.100 early monitoring of stripe rust and leaf rust with infrared spectroscopy, S2.80 effect of climate on the distribution of Fusarium spp. causing crown rot, 1130 effect of intermittent pre- and post-anthesis moisture patterns on Fusarium head blight, S2.7

effect of levels of residue on severity of Stagonospora nodorum blotch, S2.95 
effect of rain and simulated rain on deoxynivalenol levels, S2.97

effectiveness as a cover crop to reduce incidence of Pseudomonas syringae, S2.147

epidemics of stripe rust and races of Puccinia striiformis identified in the U.S. in 2012, S2.155

evaluation for Xanthomonas translucens pv. undulosa resistance, S2.127

evaluation of Fusarium graminearum root isolates to cause crown rot, $\mathrm{S} 2.48$

evaluation of spring wheat germplasm for resistance to tan spot, S3.1

factors limiting trichothecene contamination of grains after Fusarium culmorum infection, 682

fine mapping of leaf rust resistance gene LrZH84, 169

fungicide application timings for Zymoseptoria tritici are an effective antiresistance strategy, 1209

Fusarium graminearum infection and deoxynivalenol concentrations, 460 genetic variation in Cochliobolus sativus isolates, $\mathrm{S} 2.78$

histologic characterization of wheat leaf rust resistance in Thatcher isolines, S2.37

identification and mapping of a resistance gene to and unadapted isolate of Colletotrichum cereale, 575

identification of pathogens through volatile organic compounds, S2.43

incidence of viruses in wheat curl mites in maturing wheat heads, S2.143

iturin levels linked to biological control of Fusarium head blight, 146

lipid profiles in cultivars resistant and susceptible to tan spot, 74

networks of stored diseases and pests, S3.4

potential of infection by Magnaporthe oryzae in the U.S., S3.8

Puccinia infection in the Ecuadorian highlands, S2.108

role of deoxynivalenol in seedling infections

by Fusarium graminearum, S2.21

root rot disease survey in South Dakota, S2.48

seedling leaf rust resistance in Thatcher isolines, $\mathrm{S} 3.3$

spiked-based simulation model for wheat blast incidence, S3.3

warning system for foliar disease in the Grand-Duchy of Luxembourg, S2.38 See also Spring wheat; Winter wheat

Wheat bacterial leaf streak resistance, S2.127

Wheat blast, spiked-based simulation model for incidence, S3.3

Wheat bunt, identification and annotation of the mating locus in, S2.93

Wheat curl mites, S2.143

Wheat head blight, mechanisms and management

of cardendeazim resistance, $\mathrm{S} 2.184$

Wheat leaf rust

early monitoring based on infrared spectroscopy, S2.80

operational warning in winter wheat, $\mathrm{S} 2.38$

See also Puccinia triticina

Wheat leaf rust resistance

fine mapping of resistance gene $\mathrm{LrZH} 84,169$ histological characterization, S2.37

screening winter wheat germplasm for, S3.5 seedling resistance in Thatcher isolines, S3.3

Wheat stem rust

efficacy of disinfestants in killing urediniospores of, S3.2

temporal evaluations on the infection process on barley, S3.9

virus induced gene silencing, S2.36
Wheat stem rust resistance identification of Rpg5 gene, 1153 screening winter wheat germplasm for, S3.5

Wheat streak mosaic disease, effect of nitrogen fertilization on, S2.97

Wheat streak mosaic virus (WSMV)

effect of deletions in the coat protein cistron on disease symptoms, S2.143

effect of nitrogen fertilization on, S2.97

estimating susceptibility in noncrop grasses, S2.22

genetic variation in, 98

incidence in wheat curl mites in maturing wheat heads, S2.143

Wheat stripe rust

identification of Berberis spp. as alternate hosts, 927

local dispersal from single source lesions, S2.41

QTL mapping of resistance in spring wheat, S2.42

Wheat yellow mosaic virus (WYMV), 949

Wheeler, D. L., S2.159

Wheeler, T., S2.94

Wheeler, T. A., S2.161

Wherley, B., S1.8

Whidden, A. J., S2.90

Whipple, S. D., 1235, S2.162

White, F., S2.62, S2.88, S2.167

Whitefly

multiplex PCR identification, S2.7

protein biomarkers linked to transmission

competent and transmission refractive populations, S2.65

Whitehill, J., S2.47

White leaf spot disease, field screening of

Brassica germplasm for resistance against,

S2.53

White mold. See Sclerotinia sclerotinia

White oak (Quercus alba)

ectomycorrhizal community, S2.160

Phytophthora cinnamomi and white oak decline, S2.191

White pine blister rust (WPBR), S2.143

White rot fungus, S2.180

White trunk rot of hardwoods, S2.20

Whitfield, A. E., S2.11, S3.1, S3.2, S3.7

Wideman, R., S2.114

Widholm, J. M., 984

Widmer, T., S2.160

Wiese, C., S2.160

Wildfire

effect on foliar endophytes of Quercus hypoleucoides and Juniperus deppeana, $\mathrm{S} 2.62$

See also Fire

Wild rice (Oryza rufipogon), functional analysis of the resistance gene Pid 3 -A4 by allele mining, 594

Wild rocket (Diplotaxis tenuifolia), 23

Wildung, M. R., S2.93

Wilkins, K. E., S2.171

Willer, M., S2.44

Williams, G. C., S2.135, S2.160

Williams, L., 15

Williams, M. A., S2.163

Williamson, V. M., 935

Williams, T. F., S2.87

Williams, W. P., S1.2

Willis, D. K., S2.121, S2.135

Willoughby, J. A., S2.85

Willyerd, K., S2.33

Willyerd, K. T., 906, S2.7

Wilson, A., S2.58

Wilson, L., S2.39

Wilson, R. A., S2.43, S2.90

Wilson, R. F., S2.183

Windham, M., S2.54

Wingard, J. V., S2.62
Wingfield, M. J., 400

Winter, M., 682

Wintermantel, W. M., 501, S2.160

Winter rye, effectiveness as a cover crop to reduce incidence of Pseudomonas syringae, S2.147

Winters, S. A., S1.9

Winter wheat

adult-plant resistance to Puccinia striiformis $\mathrm{f}$. sp. tritici, S2.97

calculating fungicide dose decisions for Mycosphaerella graminicola, 666

effect of Fusarium head blight-Stagnospora

leaf blotch management on yield and quality, S2.173

effect of QoIs on Fusarium head blight, S2.33

effect of rain and simulated rain on deoxynivalenol levels, S2.97

fungicide strategies in resistance management for Mycosphaerella graminicola, 690 operational warning for Septoria leaf blotch and leaf rust, $\mathrm{S} 2.38$

resistance to Puccinia striiformis f. sp. tritici, S2.97

screening germplasm for resistance to leaf and stripe rust, S3.5

Winton, L., S2.2

Wischmeyer, C., S2.140

Wise, J. C., S2.2

Wise, K., S2.123, S2.175

Wiseman, M. S., S2.160

Wisotsky, S., S2.102

Wisser, R. J., S2.36, S4.3

Woeste, K., S2.66

Wohanka, W., 1001

Wolfenbarger, S., S2.38, S2.16

Woloshuk, C., S2.80, S2.104, S2.123

Wong, J., S2.188

Wong, P., S2.180

Wong, V. L., S2.150, S2.161

Wood, B. W., S2.17

Wood, D., S2.29

Wood decay

co-expression analysis of Phanerochaete carnosa genes, $\mathrm{S} 2.180$

evolution of the Agaricomycotina, S2.181

in extreme environments, S2.180

fossil record of wood-rotting fungi, S2.180

mechanisms inferred from genome

investigations, S2.180

novel industrial lignocellulose-degrading enzymes, S2.181

in the Ozark Highlands, S2.180

Wood, E. M., S2.161

Woodhall, J. W., S2.96

Wood-rotting fungi, fossil record of, S2.180

Woodward, J. E., S1.1, S1.11, S2.161

Worchel, E., S2.161

Workneh, F., 1235, S2.162

Worobo, R. W., S2.69

Worthington, C. J., S2.106

Woudenberg, J. H. C., S2.162

Wright, K. M., 333

WRKY transcription factors, S1.4

potential roles in regulating maize defense against Aspergillus flavus, S2.45

Wscs, S2.167

Wubet, T., S2.13

Wu, D., 641

Wu, F., S2.170

Wu, H., S2.84

Wu, J., S2.69

Wu, R., S2.170

Wu, T., S2.162

Wu, Y., 1162

Xanthomonas albilineans, S2.54

Xanthomonas alfalfae subsp. citrumelonis, 409

Xanthomonas arboricola pv. corylina, S2.64

Xanthomonas arboricola pv. pruni 
and leaf abscission on peach and nectarine, S2.173

oxytetracycline resistance in, S2.11

potential role of bacteriophage in the

coevolution of on peach trees, S2.135

Xanthomonas axonopodis pv. dieffenbachiae anthurium susceptibility index, S2.6

biological control, S2.6

genetic analysis of, 237

Xanthomonas axonopodis pv. glycines, S2.25

Xanthomonas campestris, S2.170

Xanthomonas campestris pv. campestris, S2.76

Xanthomonas campestris pv. vesicatoria antibacterial activity of shiitake mycelial extracts, $\mathrm{S} 2.105$

role of sRNAs in the virulence of, S2.187

Xanthomonas campestris pv. vitians

detection and characterization of strains, S1.3 internal colonization of lettuce leaves, S2.21

Xanthomonas citri

mechanism of avirulence factor AvrGf1 in inducing hypersensitive response on citrus, S2.168

specificities of TAL effectors, S2.131

Xanthomonas citri pv. citri

effect of postharvest treatments on survival, S2.6

See also Citrus canker

Xanthomonas citri subsp. citri

acquisition of copper resistance genes, 409

characterization of a variant triggering a hostspecific disease response, 555

comparison of culture and bioassay for detection of, S2.17

convergence of TAL effectors on a single host susceptibility gene, S2.62

evaluation of Citrus sinensis for resistance to, S2.50

Flg22-triggered defense responses in mandarin and grapefruit, S2.132

pan-genome analysis, S2.67

Xanthomonas cucurbitae

chemical and biocontrol agents for management in pumpkin, S2.144

detection in pumpkin seed, S2.119

pathogenic and genetic variation among isolates, $\mathrm{S} 2.119$

Xanthomonas fragariae, S2.155

Xanthomonas hortorum pv. perlargonii, S2.94

Xanthomonas oryzae

characterization of host transcription in response to infection by, $\mathrm{S} 2.88$ detection by loop-mediated isothermal amplification, S2.76

detection of pathovars from rice seed, S2.152

Xanthomonas oryzae pv. oryzae, S2.118

Xanthomonas perforans

characteristics of strains from Florida

tomatoes, S2.146

development of biopesticide extractives from switchgrass, S2.109

effect of photocatalytic nanoscale formulations of titanium dioxide on, 228

Xanthomonas spp.

acquisition of copper resistance genes in

citrus-associated Xanthomonads, 409

causing common bacterial blight disease of

common bean, multilocus sequence analysis, S2.106

contributions of type III/TAL effectors to pathogenicity, S2.170

flagellar motility and fitness in, S2.171

genome and transcriptome analysis to reveal adaptation mechanisms, S2.170

patterns of host transcriptome modulation as a measure of TAL effector content, S2.171

Xanthomonas translucens pv. undulosa, S2.127

Xanthomonas vesicatoria, S2.6

Xflg22, S2.132
Xia, C., S2.156

Xiang, Y., S2.124, S2.163

Xiao, C. L., S2.22, S2.133, S2.160, S2.163

Xia, X., 169

Xia, Y., S2.163

Xie, F., S2.46

Xie, G., S2.115

Xie, L., 1162

Xie, L.-H., 949

Xiong, Q., S2.188

Xiong, Z., S2.94

XopAG effector, S2.50

XopAJ effector, S2.148

Xue, B., 175, S2.129

Xue, C., 641

$\mathrm{Xu}$, J., 594

Xu, J. R., S2.53, S2.81, S2.167

$\mathrm{Xu}$, J.-R., 400

$\mathrm{Xu}, \mathrm{L} ., \mathrm{S} 2.84$

$\mathrm{Xu}, \mathrm{Q} ., \mathrm{S} 2.163$

$\mathrm{Xu}, \mathrm{S} ., \mathrm{S} 3.2$

$\mathrm{Xu}, \mathrm{X} ., 594$

Xu, X.-M., 108, 768

Xylanase, S2.152

Xylella fastidiosa

bacterial leaf scorch of amenity trees in Washington D. C., S4.2

cell-cell signaling and endophytic behaviors, S2.186

characterization of the popP gene, S2.132

characterization of toxin-antitoxin systems, S2.78

disruption of biofilm production, $\mathrm{S} 2.102$

effects of grapevine sap phenolics on in vitro growth, S2.154

effects of rootstock on infection and grapevine sap phenolics, S2.154

identification of genes undergoing adaptive evolution in, S2.44

incidence and severity in a New Jersey urban forest, S2.51

PhoP/Q regulatory system, S2.191

pilYI homolog responsible for twitching

motility response to calcium, $\mathrm{S} 2.32$

role of a thioredoxin family protein in

virulence, S2.69

role of cell surface lipopolysaccharide in grapevine colonization and insect acquisition, S2.119

synthetic detection circuits targeting diffusible signal factor, S2.148

therapeutic and prophylactic application of phage, S2.34

zinc regulation of biofilm and

exopolysaccharide production in, $\mathrm{S} 2.101$

Xylella fastidiosa subsp. fastidiosa, S2.107, S2.126

Xylella fastidiosa subsp. multiplex, S2.14, S2.107

Xylem discontinuity, 682

Xylogone ganodermophthora KACC93082P, $\mathrm{S} 2.71$

Yaghmour, M. A., S2.84, S2.163

Yahr, R., S2.149

Yang, B., S2.62

Yang, C. C., S2.28

Yang, F.-J., 888

Yang, H., S2.167

Yang, H. C., S2.164

Yang, J., 949, S1.2

Yang, P., S2.30

Yang, Q., S4.3

Yang, X., S2.164, S2.189

Yang, X.-B., 400

Yang, Y., S2.164

Yan, Y., S2.62

Yao, J., S2.11

Yao, J. N., 927

Yashuhara-Bell, J., 1220
Yasmin, T., S2.164

Yeasts, gut-inhabiting, S2.150

Yeh, H. H., S2.82

Yellow bud in onion, S1.3

Yellow pine forests, response of ectomycorrhizal communities to recurring prescribed fires, S2.107

Yellow vein disease of blackberries, S2.87

Yellow vein diseases, of ornamental plants, S1.5

Yepes, M. C., S2.145

yidR gene, 362

Yin, C., S2.36, S2.164

Yli-Mattila, T., 400

Yokomi, R., S2.156, S2.157

You, M., S2.53

Youngblood, S. B., S2.177

Young, C. A., S2.44, S2.55, S2.133, S2.142, S2.165

Young Kelly, H. M., S2.165

Young, M. E., S2.59

Young, R. F., S2.34

Yuan, J. S., S2.119

Yuan, Q., S2.165

Yuen, G. Y., S2.138, S2.168

Yuen, J., S2.145, S3.8

Yu, F. Q., 245

Yu, J., S2.184

Yu, J. M., S2.155, S2.164, S2.165

$\mathrm{Yu}, \mathrm{L} ., \mathrm{S} 2.84$

Yu, N., 255, S2.94

Yu, S. H., S2.165

Yu, W., S2.167

Zablotowicz, R. M., S2.176

Zalamea, P. C., S2.48

Zambell, C. B., S2.165

Zamora-Segura, R., S2.16

Zamudio, K. R., S2.15, S2.67

Zancan, W., S3.9

Zanne, A., S2.180

Zanotto, E., S2.166

Zasada, I. A., S2.139

Zaunbrecher, J., S2.106

Zebra chip disease. See 'Candidatus Liberibacter

solanacearum'; Potato zebra chip disease

Zeglin, L., S2.182

Zeller, K. A., S2.30

Zeng, F., S2.166

Zeng, Q., S2.2

Zerillo, M., S2.64, S2.65

Zernova, O. V., 984, S3.7

Zhai, Y., S2.110

Zhang, B., S2.46

Zhang, C., S2.166

Zhang, D., S2.84, S2.87

Zhang, G., 1103, S2.166

Zhang, H., 1162, S2.167

Zhang, H. C., 927

Zhang, H. M., S2.94

Zhang, J., S2.62, S2.82, S2.105, S2.167

Zhang, M., 15

Zhan, G. M., 927

Zhang, N., 400, S2.96, S2.173

Zhang, S., 15, S2.44, S2.95, S2.98, S2.111, S3.6

Zhang, T., S2.83, S2.87

Zhang, X., S2.166, S2.167, S2.183

Zhang, Y., S2.7, S2.45, S2.66, S2.184

Zhao, B., S2.46, S4.2

Zhao, G., S2.53

Zhao, J., 927

Zhao, L., S2.167

Zhao, S., S2.170

Zhao, S. Y., S2.54

Zhao, X., 594

Zhao, Y., S2.6, S2.26, S2.172, S4.1

Zheng, D., 427, 633

Zheng, Z., 623 
Zhivaeva, T., 972

Zhongguo, X., 255

Zhong, S., S2.78

Zhou, H., 600

Zhou, J., 966, S1.11

Zhou, L., S2.72, S2.184

Zhou, M. G., S2.184

Zhou, T., S2.184

Zhou, X., S1.5, S2.53, S2.81, S2.168

Zhou, X. G., S2.168
Zhou, Y., 169, S2.163, S2.184

Zhou, Z., 594

Zhuang, W. Y., S2.125

Zhu, H.-M.-Y., 135

Zhu, L., 594

Zhu, M., S2.189

Zhu, T.-H., 135

Zimmerman, K., S2.54

Zinc, regulation of biofilm and exopolysaccharide production in Xylella fastidiosa, S2.102
Zitter, S. M., S2.101

Zitter, T. A., S2.101

Zoysiagrass, large patch management, S1.8

Zucchi, T. D., S2.166

Zurn, J., S3.9

Zygomycetes

hyphal tip ultrastructure and cytoplasmic organization, S2.44

spindle pole bodies, S2.93

Zymoseptoria tritici, 1209 